
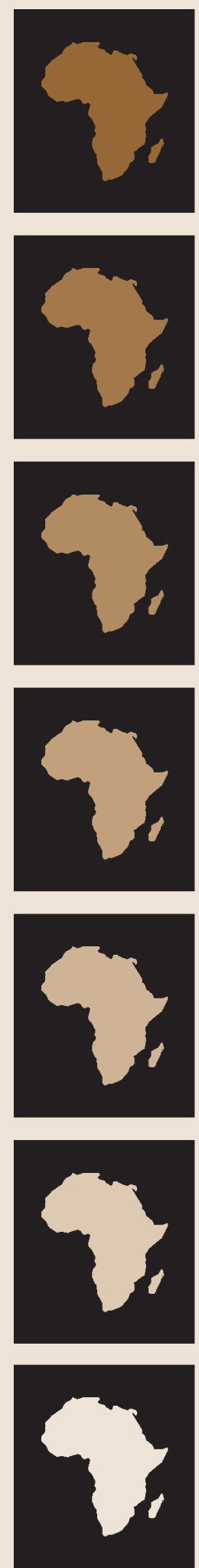

\section{JOURNAL OF AFRICAN ELECTIONS}
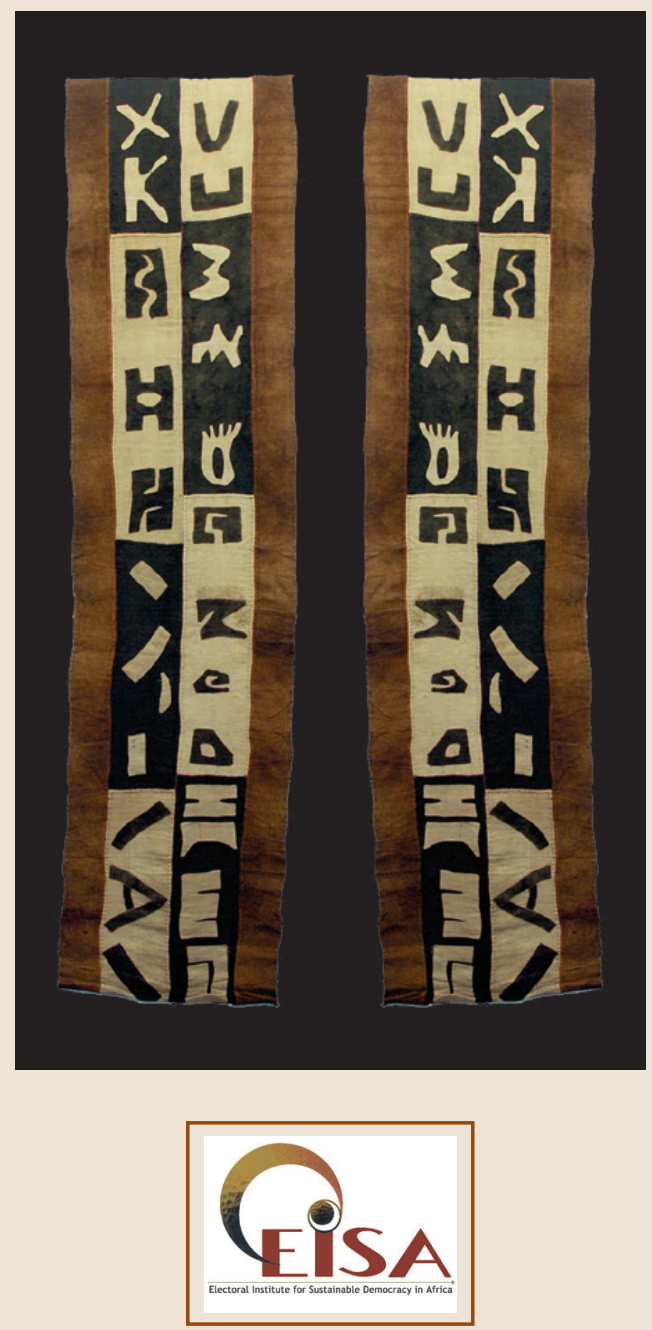

Volume 18 Number I June 2019 

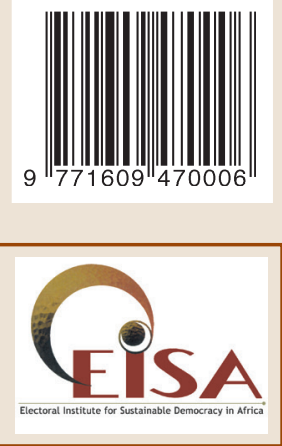


\title{
Journal
}

\section{of African Elections}

\author{
EDITOR \\ Denis Kadima
}

\author{
Articles By \\ Stephen Chan \\ Albano Agostinho Troco \\ Samuel Adams \\ William Asante \\ Joseph Olusegun Adebayo \\ Blessing Makwambeni \\ Philip Onguny \\ Gift Dorothy Makanje \\ Kabale Ignatius Mukunto
}

Volume 18 Number 1 June 2019 
Published by EISA

14 Park Road, Richmond, Johannesburg, South Africa

P O Box 740, Auckland Park, 2006, South Africa

Tel: +27(0) 113816000 Fax: +27(0)11 4826163

e-mail: publications@eisa.org.za

(C) EISA 2019

ISSN: 1609-4700 (Print) ISSN 2415-5837 (Online)

v. 18 no. 1: $10.20940 /$ jae/2019/v18i1

All rights reserved. No part of this publication may be reproduced, stored in a retrieval system or transmitted in any form or by any means, electronic, mechanical, photocopying, recording or otherwise, without the written permission of the publisher

Printed by: Corpnet, Johannesburg

Cover photograph: Reproduced with the permission of the HAMILL GALLERY OF AFRICAN ART, BOSTON, MA, USA

For electronic back copies of JAE visit www.eisa jae.org.za 


\section{EDITOR}

Denis Kadima, EISA, Johannesburg

MANAGING EDITOR

Heather Acott

EDITORIAL BOARD

Chair: Denis Kadima, EISA, South Africa

Cherrel Africa, Department of Political Studies, University of the Western Cape, South Africa Jørgen Elklit, Department of Political Science, University of Aarhus, Denmark

Amanda Gouws, Department of Political Science, University of Stellenbosch, South Africa

Roukaya Kasenally, Department of Social Studies, University of Mauritius, Mauritius

Abdul Rahman Lamin, UNESCO Regional Office for Eastern Africa, Nairobi, Kenya

Tom Lodge, Department of Politics and Public Administration, University of Limerick,

Ireland

Khabele Matlosa, Political Affairs Department, African Union Commission

Roger Southall, Department of Sociology, University of the Witwatersrand, South Africa and

Research Associate in Political Studies, University of Cape Town.

The Journal of African Elections is an interdisciplinary biannual publication of research and writing in the human sciences, which seeks to promote a scholarly understanding of developments and change in Africa. Responsibility for opinions expressed and for the accuracy of facts published in papers, research notes, review articles and book reviews rests solely with the individual authors or reviewers. Contributions are referred to specialist readers for consideration, but the Editor is responsible for the final selection of the contents of the Journal.

Editorial correspondence, including manuscripts for submission and books for review, should be sent to:

The Managing Editor, Journal of African Elections

EISA: P O Box 740

Auckland Park 2006, South Africa

Tel: +27(0)113816000 | Fax:+27(0) 114826163 | e-mail: jae@eisa.org.za

Business correspondence, including orders and remittances, subscription queries, advertisements, back numbers and offprints, should be addressed to the publisher:

The Publications Department, Journal of African Elections

EISA: P O Box 740

Auckland Park 2006 South Africa

Tel: 27(0)113816000 | Fax:+27(0)114826163 | e-mail: publications@eisa.org.za

Abstracts for previous issues are available at: https://eisa.org.za/index.php/journal-of-african-elections-contents-listing/ 


\section{CONTENTS}

Free and Fair?: Observation of Selected African Elections

Stephen Chan 1

Electoral Politics and Political Transition in Post-War Angola: Progress,

Problems and Prospects

Albano Agostinho Troco

Biometric Election Technology, Voter Experience and Turnout in Ghana Samuel Adams and William Asante.

The Limits of Peace Journalism: Media Reportage of Kenya's 2017 General

Elections

Joseph Olusegun Adebayo and Blessing Makwambeni

Electoral Violence in Kenya 2007-2008: The Role of Vernacular Radio Philip Onguny....

Crimes involving Dishonesty or Moral Turpitude in Malawi's Elections Gift Dorothy Makanje.

Electoral Violence and Young Party Cadres in Zambia

Kabale Ignatius Mukunto. 


\title{
FREE AND FAIR? \\ Observation of Selected African Elections
}

\section{Stephen Chan}

Stephen Chan is Professor of World Politics at SOAS, University of London

\begin{abstract}
The first large-scale election observation was of Zimbabwe's 1980 independence elections. Since then, election observation has become a regular worldwide feature and many international organisations, official agencies, and non-governmental organisations field observation teams. They all use similar methodologies, largely derived from the original 1980 model. A third of a century later, it may be time to consider whether the use of electoral observation has outlived its usefulness - or is itself being used to mask forms of electoral cheating. This paper considers five $21^{\text {st }}$ century African elections - in Kenya (2007), Zimbabwe (2008, 2013 and 2018) and Zambia (2016), through the reflections of a pioneer of the 1980s observation prototype.
\end{abstract}

Keywords: election observation, free and fair, peaceful and credible, plausible, algorithm

\section{PERSONAL NOTE}

I was a member of the Commonwealth Secretariat in the 1970s and 1980s. Under its Secretary-General, Shridath Ramphal, it played a major diplomatic and advisory role leading to the Lancaster House negotiations in late 1979, which established the preconditions for Zimbabwe's independence after years of war between Rhodesian white settlers and two guerrilla armies who sought majority rule. ${ }^{1}$ Those preconditions included an election, free campaigning by those previously outlawed, and a truce. Ramphal had inserted into the final Lancaster House agreement a provision that the elections and campaign were to be observed independently of the warring parties and the British government that temporarily assumed responsibility for the country (Chan 1988, pp. 42-45). In the second part of January 1980, just over a week before Commonwealth observers

1 For a dissident guerrilla view, see Wilfred Mhanda, 2011 Dzino: Memories of a Freedom Fighter, Weaver, Harare. 
were to be despatched, a small party from the Commonwealth Secretariat was sent to Rhodesia with the brief both to establish a headquarters for observation, and to work out whether and how observation could be conducted. There were no detailed instructions. Electoral observation had not been attempted before, certainly not on this scale, Rhodesia being about three quarters the size of California. Peter Snelson and I conducted a rapid reconnaissance of the country in a single week, and our report formed the only field input for the plan then devised by Ramphal's representative, Moni Malhoutra, for observation and the deployment of observers. Both in this first week, and in the weeks of observation that followed, and with barely a thought for the health and safety of the observers in a war-torn land, we - the organisers - had no advance idea of what we were doing. We were involved in an extemporisation, under hazardous conditions, which assumed a pattern of work and did the job - in the end, I think, very well (Chan 1985). Since then, until 2010, I have attended many elections in Africa and elsewhere, but always as a solo observer. In 2010, I was invited to lead one of the teams of an electoral observation group in the Sudanese elections which were part of the prelude to South Sudanese independence a year later. The Carter Center, the African Union, and the Arab League sent observer groups as well and all used methodologies essentially no different from those of 1980. They had become bureaucratically more robust (or fussy), but they had acquired no greater depth or forensic capacity. After acting as a solo observer in the 2013 and 2018 Zimbabwean elections and Zambia's 2016 elections, and watching the observer groups as well as the elections very closely, I concluded that electoral observation, while not worthless, has limited worth.

\section{DEVELOPMENTS IN ELECTION OBSERVATION}

The success of the 1980 Zimbabwe observation was almost immediately shaded by a less successful observation of the elections in Uganda later that year. Emboldened by its Zimbabwean success, the Commonwealth Secretariat sent an observation group to an election with very different conditions. ${ }^{2}$ After the fall of Idi Amin in 1979, facilitated by the Tanzanian army as well as Ugandan rebel irregulars, unsuccessful interim governments were formed under Yusuf Lule (April-June 1979), himself a former Commonwealth Assistant Secretary-General; Godfrey Binaisa (June 1979-May 1980); and Paulo Muwanga, who served for ten days in May before a presidential commission took over. This ended with the elections of

2 For an early contemplation of the differences, see Simon Hardwick, 1982, 'Administrative aspects of the Uganda election - December 1980: A comparison with Zimbabwe', Public Administration and Development, vol. 2 p. 2. 
December 1980 which were won by Milton Obote, whom Amin had overthrown in 1971 and who had taken exile in neighbouring Tanzania.

But Tanzania, which had overthrown Amin, was a key power-broker in Uganda. It wanted stability in its neighbour and Obote was the preferred choice of Tanzanian President Julius Nyerere. That in itself was unavoidable, given the terrible administration of Amin, but the 1980 elections were certainly unfair, and to a greater or lesser extent rigged. Certainly, afterwards, one of the Commonwealth Secretariat members present accepted that they were rigged. The electoral commission was not impartial and the country had insufficient public administrative infrastructure to hold a nationwide election. The Economist described the Commonwealth Observer Group (COG) as 'shameful' for validating it despite the misgivings of its own chairman, although a critical but more measured academic response suggested the Commonwealth sought to maintain some means of influencing Obote in his future conduct as president (Willis, Lynch \& Cheeseman 2017, pp. 211-238). Figures like the current Ugandan President, Yoweri Museveni, immediately took to the bush to wage guerrilla war.

The difference with Zimbabwe was that, under Amin, Uganda lacked not only public administration but effective government. Rhodesia always had a government and the strategy of the guerrillas was to deny it governmental space, but large parts of the country remained under discernible government. The United Kingdom assumed responsibility for the tasks of government in the interregnum between Rhodesia and Zimbabwe, but was anxious to be rid of the whole affair, albeit without losing face or causing domestic backlash back home, as many British citizens were related to the white settlers. Even so, the UK had no strategic interests in Zimbabwe; whereas Tanzania had every strategic interest. The Tanzanians had invaded Uganda only after Amin had first invaded Tanzania. The Tanzanians wanted a guarantee that this could not happen again and wanted a reliable and familiar man in charge. Whereas a polyglot Commonwealth military force of British, New Zealand, Kenyan and Fijian troops went to Zimbabwe to help keep the peace during the electoral period, peacekeeping in Uganda was entirely conducted by the Tanzanian army under a central command with directive capacities in many parts of the country. Finally, the opposing forces largely kept the truce in Zimbabwe, but disparate armed groups maintained hostilities at various levels throughout the Ugandan elections. Observation required Tanzanian security, and the COG was nowhere as intrepid and determinedly independent as its predecessor in Zimbabwe as it had less capacity to observe. Tanzania was a Commonwealth member with an illustrious record of support for liberation and efforts at egalitarian socialism. It was not to be gainsaid, and the result it sought in the election was validated by the Commonwealth. Observation had become part of the regional power politics of East Africa. 
The term 'free and fair' was first used at the Zimbabwean elections. ${ }^{3}$ It was used again, albeit in a qualified way, to scepticism and criticism in Uganda (Namusoke 2016) but it established these loose terms as undefinable and partially adjustable litmus tests for elections that lasted until 2013. In an attempt to avoid a repeat of the violence and 'electoral cleansing' of 2007 in Kenya, on 27 February 2013 the UN Secretary-General, Ban Ki-Moon, talked of the need to be 'credible and peaceful', probably without the intention of devising a lower standard. That is the heart of this paper.

\section{METHODOLOGIES OF ELECTORAL OBSERVATION IN 1980 AND 2016}

The very early Commonwealth decision in Zimbabwe was that observation had to be decentralised. The British Governor, Nicholas Soames, had undertaken to mount a separate observation exercise in which observers - usually sent by governments, together with journalists - would fly from the capital to and from chosen locations on a daily basis. They would have a military escort to ensure safety and as many observers who wanted to come would be welcomed. In part, the political rationale was to create a range of opinions about the elections so that, in the event of dispute over the results, at least some voices would declare that a proper exercise had taken place, though safety was also a genuine factor. Thus, decentralised Commonwealth observation, without inbuilt security, was clearly an exercise in risk. Observers were rotated around the various decentralised zones on a weekly basis, and a small secretariat remained in place in all zones to prepare the observation and, crucially, to liaise with all parties and all security forces. There were four major armed groups in total, of which three were full armies (also dispersed into centres) and one a smaller para-military group, as well as a peacekeeping unit from four different foreign armies. The administrative organisation of the election was decentralised to provinces and districts, so observation mirrored electoral, military, and public administrative decentralisation. By and large, modern electoral observation has sought to spread itself throughout the country being observed, but without rotation of observers (there were four full rotations in Zimbabwe), without a presence more than a month before the elections, and without on-site secretariats. Certainly, there has been an effort not to depend on security forces from the incumbent government, but an entire float of health and safety procedures have meant that observation tends to avoid what may be still war-zones or zones of great volatility. In the South Sudan elections of 2010, UN peacekeeping bases were meant to provide

3 It was the declared intention of the British government to hold 'free and fair' elections. The conclusion of the Commonwealth Observer Group was that it was 'a valid and democratic expression' (Commonwealth Secretariat 1980, p. 74). 
accommodation on request from travelling observers, but the Chinese and Kenyan peacekeeping camps did not comply. ${ }^{4}$ Although the Ukrainian and Canadian camps did, many regions were under curfew, so observers were discouraged from travelling to areas where observation was most needed for fear of being stranded without shelter as curfew fell. Decentralised observation has continued since Zimbabwe.

What has developed most radically since 1980 has been the use of bureaucratic check lists. These can be easily tabulated to give 'scores' for different aspects of electoral conduct. There are generally tick boxes for whether party agents were the prescribed distance from the polling desks, whether special assistance was available for the disabled and elderly, whether all documents, ballots and ballot boxes were in place, whether voters' rolls were accessible, etc. Observers tick off the boxes and move onto the next polling station. The 1980 Zimbabwe observation used no such formal lists, but by and large sought to observe exactly such indicators of good polling practice. The result over the years is two-fold: observation groups publish tabulated results that give an impression of nationwide electoral practice; governments and electoral commissions mount very good election days with good procedures conforming to accepted international norms, precisely for the benefit of observers. The focus on the election day itself, and the final days of campaigning when observers disperse to decentralised stations, means that campaigning in the weeks prior (such as access to rallies, advertising, media, whether or not harassment and violence took place, and by whom) may be common knowledge and the subject of reportage, but not always observation. Election day itself might be 'free and fair' - people could vote freely, all contesting parties were represented on the ballot fairly - but the preceding campaign may have been fraught to the point that it was not 'credible and peaceful', let alone always 'free and fair'. The timing of dispersal of observers to decentralised points becomes critical. A contentious election requires at least one month of decentralised but coordinated observation. But early dispersal requires careful and detailed briefing as to what should be observed, as there are few universal campaign indicators that are not also heavily generalised. For instance, subtle psychological intimidation of voters by means of cultural signs or local language may not be appreciated by foreign observers. A youthful party militant rattling a box of matches in a marginal seat was taken by local people as a threat to burn property if the vote went against the government. The expression, in Shona, 'the spirits see through all barriers', was interpreted as a statement that polling booths and especially transparent ballot boxes could not hide the identity of voters who chose the opposition. The severe beating up of an opposition supporter was calculated, perhaps tabulated,

4 Personal experience in South Sudan at the time. 
to spread fear among his family, relatives and friends. Here, an injured body that lives to tell the tale is of much greater use than a dead one. But this kind of multiplier effect might not make an impact on observers who would report on the small incidence of such beatings. It is where intimidation oversteps its own restraints - threats by inference, exemplary but not wholesale violence - that it becomes naked and of concern to observers and the international community. The 2007 Kenyan elections were a case in point.

Before we look at those elections, what are the positive practices and oversights that derived from 1980? Certainly, dispersal ahead of polling day - but with various time-frames involved - is a feature, i.e. the observation is decentralised; it is not confined to observing a results-verification process at an electoral headquarters but seeks to observe voting and counting of votes on a widespread basis. Secondly, close observation of the actual polling process is a continuing feature, with especial attention to rules pertaining to fairness of access and, particularly, the absence of visible intimidation.

The politesse of observation developed from 1980, when it was treated with suspicion and could be dangerous. Now, it is as if an election could not be 'proper' without highly visible observation, and the observers are not so much intrepid pioneers as members of a tour bus party. They arrive in uniform gilets and badges and many are veterans of several observations and may be doing it for the per diems. In Zambia 2016, they seemed uniformly comfortable - which is to say they did not seem prepared for hardship zones. In a personal and purely anecdotal assessment many were portly and some were amazingly fat and ate conspicuously well.

But they shared a certain ignorance and naivety in 1980 to do with the lack of advanced in-depth information about national political culture, political organisation, past electoral trends, and efforts to model possible outcomes. In 1980, there had been no previous elections in which the liberation parties had participated, so there was no relevant electoral history, and computer modelling was not known. In Zambia in 2016, it was foreign embassies who were computer modelling results and trends, but no observer group. This is to say, and I shall elaborate later in this paper, that the observation process remains exactly as lowtech as it was in 1980.

\section{KENYA 2007}

The Kenyan presidential and parliamentary elections of 2007 were highly cynical. Both presidential candidates, Mwai Kibaki and Raila Odinga, had worked together in the outgoing government. Both were highly credible and experienced candidates, and it was Odinga who wore such mantle of liberation as a son of 
Odinga - a figure of true importance in ending colonialism - could wear. Both men were capable of ethnic mobilisation, were well prepared to do so and to deploy such mobilisation forcefully, having also the ability to call it off at a moment's notice. Each knew the other's strengths and weaknesses and knew, no matter how difficult the campaign, they could work together again afterwards if they had to - even if there was no love lost between them.

Odinga was seen in the final months of the presidential campaign as the clear favourite. In a rare African country where opinion polls have some substance the aggregate of opinion polls in September and October had him ahead. With the exception of one week in November, weekly polls in October and November had him remaining ahead of Kibaki. The elections in December had three curious aspects:

1. The early counting had Odinga ahead, so any rigging against him would have occurred in the later stages of counting.

2. In the parliamentary contest, Odinga's party won 99 seats to Kibaki's 43 - although many parties were involved in a complicated contest.

3. Even so, Odinga's clear parliamentary majority over Kibaki, a margin of 2 to 1 seats, was belied by final presidential results that gave Kibaki 4578034 votes to Odinga's 4352993.

Great violence along ethnic lines erupted (Cheeseman 2015, pp. 166-7), and it took an incisive mediation by Kofi Annan to force the two sides to compromise on a coalition government.

In July, however, a US government-commissioned poll had Odinga ahead of Kibaki by $46 \%$ to $40 \%$ (Kelley 2008), with a 1.3\% margin of error. What Annan's mediation did was to restore peace, force compromise, institute measures that sought to prevent a recurrence of such violence, and propagate a principle that inclusiveness was a greater virtue than electoral victory. What it did not do was to preserve an ethos of democracy, i.e. that choice was the essence of an election. This election was almost certainly rigged (Bloomfield 2008). Nevertheless, the principle was carried forward by Thabo Mbeki at the 2008 Zimbabwean elections, although he had certainly pioneered a similar principle in earlier talks in Democratic Republic of Congo. What did all this mean for electoral observation?

There were many observer groups present, including those from the EU, and their report concluded that 'the 2007 General Elections in Kenya fell short of key international and regional standards for democratic elections' (EU Commission 2007). It used no stronger language, although much of its language continued this disapproving tone. The report was comprehensive, but it gives no evidence of contemplating available electoral data: 
1. past election results, projected forwards taking into account
a. boundary changes
b. demographic changes

2. opinion polling data, interrogated for location and demographic factors

3. variance of polling data with regard to urban locations and ethnic mix

4. early trends in counting adjusted for urban factors

5. final voting profile against each of the preceding four data-sets.

The observer groups would have, thereby, some sort of template against which to measure sudden shifts in voting pattern. Those sudden shifts would demand enquiry.

Rumour and anecdote refer to the fabled 'Israeli consultants', supposedly ex-Mossad, who apparently rig the results so that they are entirely in line with plausible variations against the template indicated above. Such rumours were abundant in the Zimbabwean elections a year after those in Kenya. Thus, 'rigged' elections are no longer won in a banal way with $90 \%$ of the vote cast for an incumbent, but with $50.1 \%$, and founded on a spread and pattern of votes gained that are both plausible and within margins of error of early opinion polls and forecasts. The algorithms for this are basic and may exist only in rumour; but observer groups should at least have the capacity to understand the possibilities and plausibilities of both honest and dishonest elections.

Africa-wide protocol now has polling figures posted at every polling station. If there are 3000 polling stations, there are 3000 sets of results. It is impossible to have observer teams at each. However, party agents with smart phone cameras can be at each station and photograph each set of results. Alternatively, party agents and election officials can agree the final result, i.e. a 'parallel vote tabulation' and an official result can be made identical by a bureaucratic process. Where there is neither uniform process nor reliable photographs, the central vote verification system becomes critical - and it is at this point that modern coordinated rigging must occur. Observer access to the verification procedures becomes critical, preferably armed with data that indicates what is plausible and what is not.

Intimidation, violence and fake ballots have not necessarily disappeared. Fake ballots lose their utility in the sense that a paper trail is left and the risk of discovery is greater the more widespread is their use. This also means that a large number of people would be involved and people talk. Intimidation is slowly becoming less often a tactic of first recourse as people affected can talk to observers and broadcast moving pictures of violence on social media. The cleanest rig is still one conducted centrally by a small number of highly-skilled people. But Zimbabwe's 2008 election combined mass intimidation with a slow-motion count that suggested manipulation. 


\section{ZIMBABWE 2008}

These elections were set against previous attempts by the MDC opposition leader to achieve electoral victory, with earlier failures set against accusations of rigging (Chan 2003; Chan 2011). The problem was that no one plausibly explained how the rigging was conducted. However, by 2008 the government of Robert Mugabe and his Zanu-PF government had clearly achieved economic failure. There was drastically reduced agricultural output and revenues because of farm seizures and, above all, hyper-inflation of gigantic proportions. Amazingly, the government failed to recognise its own unpopularity, so the first round of the elections was not as badly marred by violence and intimidation as was the case in an unexpected second round. Election day itself, in keeping with the now-established practice of 'a good show for observation', was peaceful and the electoral process was well conducted.

The build-up to polling day was in some ways soporific. It was as if ZanuPF was so confident of victory it wasn't really making an effort. A survey of its advertisements gives an indication: of the 21 different newspaper advertisements Zanu-PF published, only one, at the end of the campaign, listed their positive qualities. Nine were largely vituperative attacks on opposition leader, Morgan Tsvangirai. Three were attacks on the third presidential candidate, Simba Makoni. Three attacked international sanctions. Five dealt with electoral issues such as land and education. Almost all were shoddily designed, as were street posters and hoardings. However, in the last week there were well-designed, glossy hoardings of a besuited Robert Mugabe, shaking his fist, defending Zimbabwe against foreign ownership, set against a beautiful green and blue backdrop of Victoria Falls. But it was the Zambian side of the Falls (Chan 2011). Campaign research could not be described as a strong point.

Zanu-PF's own opinion polling indicated it would win with $57 \%$, with just 27\% for Tsvangirai and 14\% for Makoni, but the details of the polling methodology were never released. Nevertheless, all this added to a sense of Zanu-PF confidence on the eve of the elections.

As the first results were announced, and a trend began to emerge with Tsvangirai ahead of Mugabe by 2 to 1, the announcement of results slowed, then ceased. The direction of this trend had been prefigured after polls closed the previous day. The South African Broadcasting Corporation (SABC) estimated a $52 \%$ victory for Morgan Tsvangirai. My own estimate was 56\% for Tsvangirai (in Moore 2008). But I also had Mugabe receiving not even $40 \%$, as Makoni picked up sufficient votes to deny him that. Tsvangirai's MDC first claimed $60 \%$ but later moderated that to $50.3 \%$. Some years afterwards, Ibbo Mandaza, a Zimbabwean 
intellectual insider, insisted it was as much as $70 \% .{ }^{5}$ The basic thrust of all these estimates was a defeat for Robert Mugabe in the presidential vote and for his Zanu-PF party in the parliamentary vote.

The election concluded on the evening of 29 March 2008. Tallies for each polling station were posted outside the stations on the morning of $30 \mathrm{March}$. No further central announcements were made by the electoral commission from the afternoon of 30 March. Rumours of an Israeli 'consultancy team' arriving on 31 March, began circulating the afternoon of its supposed arrival. The derivative rumours then had the Zimbabwean military commanders demanding the 'arrangement' of a 52\% vote for Mugabe, and a combined $48 \%$ for Tsvangirai and Makoni. They otherwise threatened a coup on behalf of Mugabe. The 'consultants' were anxious, however, to deliver final results that were mathematically credible, and this is where the modern science of rigging had its genesis. The results were finally announced on 2 May, so credibility was a painstaking exercise. In the end Tsvangirai received less than $50 \%$ of the votes cast although he outpolled Mugabe, and a run-off was required.

These results could not be dismissed as merely incredible and the era of dictators winning sham elections by $90 \%$ were over.

- Polling station results that had been independently verified, e.g. by photographs on smart phones with date and time records, had by and large to stand.

- Those not accurately verified, e.g. if photographs were blurred because of poor camera function, could be adjusted.

- It was important in adjusting Mugabe's tally upwards not simply to adjust Tsvangirai's downwards; instead many votes were appropriated from Makoni's total, and Makoni had no national network to protest on his behalf.

- Parliamentary results and presidential results had to indicate a degree of symmetry, i.e. it was unlikely that a huge number of those who voted for the MDC had also voted for Mugabe. The decision to allow the MDC a very narrow parliamentary majority meant that the vote for Tsvangirai could not be disproportionately lower than his party's parliamentary vote.

- Voting patterns had to be in general keeping with results from earlier elections, although there is much suspicion those too had been rigged, transferring patterns to an election of different circumstances required a mathematical logic of its own.

5 Mandaza in a private conversation with the author in Harare. Mandaza was the expert commentator on national radio as the results began to be broadcast, then were suspended. 
- Finally, the 'adjustment' in the month-long count, in a normally efficient country, had to be conducted centrally, so the role of observers at the central verification count became of great importance. It was reported that an observer slept each night in the room with the assembled ballot boxes. But there were more 9132 polling stations, and each would have filled more than one ballot box for each of the presidential, parliamentary, senate, and local council elections contested at once. All those contests attracted 4406 candidates - so a single, surely sometimes sleeping, observer could not physically monitor them all; and seals broken during the night could be easily resealed authentically by resumption of the count each morning.

- Even so, the figures indicate that a 'scientific' rig was a monumental task, so a month was probably very good going - although the need for a month indicated that no ordinary count was being conducted.

The importance of observers, in 'robust presence' at all stages of the verification count conducted centrally, becomes a key lesson here. So too does the requirement for an additional layer of observation, i.e. an observable bureaucratically verified point of agreement between official polling station tallies and what are now called parallel vote tabulations (PVT). Software used in 2008 in Cambodia does not yet seem in use in Africa (COMFREL 2008). The PVT are tallies verified by party agents and accredited observers within each polling station, i.e. they verify results posted by the polling station staff having watched the count. The process of counting requires observation, but so does the moment of agreement between the official result and the PVT. This might seem a clumsy and gargantuan process, but it doesn't even require heavy-duty software. Computer links via encrypted systems with firewalls and multiple but correlated passwords should provide at least a highly indicative preliminary picture. In some countries with less spread of WiFi, e.g. Sudan in 2010, this becomes difficult, but is less so in Zimbabwe.

In the absence of such provisions, citizen groups have tried to devise electronic tools. An app, though not as scientifically-based as the one in Cambodia, was fielded as an independent tabulation-awareness tool in Gabon in 2016 (Muisyo 2016).

Distributing reliable phones should have been a priority as not all smart phone cameras were reliable in the Zimbabwe of 2008. Many pictures of polling station tallies were taken on Chinese clone phones. In the UK, the Liberal Democratic Party sent a shipment of such phones to Zimbabwe, but they failed to make it past South African customs in time. ${ }^{6}$ Observation should not be a closed-

6 LibDem spokesman, Ed Davey, Shadow Secretary of State for the Foreign and Commonwealth Office, to the author, discussion in the House of Commons after the Zimbabwean elections, 2008. 
shop exercise conducted within an accredited group. Observation needs to reach out to civil society at least, and that should include disseminating technology for observation and as a part or adjunct of a PVT process. Observation as it is now could soon be overtaken by citizen reportage and tabulation, using far more sophisticated tools than at present.

In the runoff of 2008, Zanu-PF resorted to old-fashioned bludgeoning techniques of great and crude violence. Morgan Tsvangirai withdrew. Mugabe swept to victory with a count that lasted a single day.

\section{ZIMBABWE 2013}

These elections marked the end of the power-sharing government mediated into existence by Thabo Mbeki after the furore that accompanied the 2008 elections, and the long months of delicate and sometimes brutal negotiations that extended into 2009. Morgan Tsvangirai accepted the invented position of prime minister, despite probably having won the presidency - had the count in 2008 been straight-forward and honest. But he did not prove a good prime minister (Chan 2008). At the same time, his opposition colleague, Tendai Biti, had been a most successful minister of finance, stabilising the economy which had collapsed under hyper-inflation. What this meant for voters was not necessarily an automatic endorsement of Biti's party, but a judgement as to what power configuration would best safeguard these hard-won gains. This was a key consideration of a particularly comprehensive pre-election poll of voters' intentions. The 2012 Freedom House survey by South African academic, Susan Booysen, was scanned for its headline figures but left largely uninterrogated by some political quarters in Zimbabwe.

In a survey of 1198 respondents and a margin of error of $2.8 \%$, those headline figures had $47 \%$ of the respondents declining to provide a voting intention. This was seized upon by Tsvangirai's MDC strategists as meaning $47 \%$ were undecided. However, the survey was limited to 63 rural and 37 urban areas, consistent with population distribution. It showed consistent falls in approval ratings for both the MDC and Morgan Tsvangirai across a range of carefully calibrated survey topics, including stabilisation of the economy. And it showed falls in approval ratings across the range of topics in all the MDC urban strongholds. In those same strongholds, Zanu-PF approval ratings rose. On the key topic of 'trust', MDC approval ratings dropped below those for Zanu-PF; on the topic of capability to bring change, Zanu-PF outpolled the MDC by 29 to $22 \%$.

Booysen's report indicated to strategists that there was much to fight for, and also provided a range of topics over which to wage an electoral fight. ZanuPF took the report far more seriously than the MDC and realised that, if rigging was to be employed, the report gave a template upon which final manipulated voting figures could be based and made to look credible. By this stage, Ban Ki- 
Moon's formulation, 'peaceful and credible', had entered the lexicon. Zimbabwe's neighbours had rounded on the country to avoid the naked violence of 2008's second round, so rigging had to be accomplished without reliance on obvious intimidation and strong-arming. Credibility became the key motif in preparations for and assessments of the contest. In short, elections were managed to convince observers of their credibility, not their probity. Elections had become complex stage-managed validations rather than exercises in choice. Choice has to be convincingly against the incumbent, to the extent that an incumbent win would not be credible.

As it turned out, the election was won by President Mugabe and his ZanuPF Party, certainly with irregularities in the electoral process - the voters' rolls begged various significant questions - but it would seem that the irregularities were designed to deny the opposition a constitutionally-blocking third of the parliamentary seats. Without any rigging, Zanu-PF could plausibly still have won by $52 \%$. Even so, the spread of the vote was such that had the MDC healed the splits with breakaway factions and not faced a split opposition vote, and had it mounted a youth registration drive to ensure a greater youth turnout, the result would have been much closer. As it was, Mugabe defeated Tsvangirai by 2110 434 to 1172349 votes; and Zanu-PF took 197 parliamentary seats to the MDC's 70 , with 3 seats taken by others.

Nonetheless, in line with key aspects of the MDC's post-election complaints, Mugabe would still have won even had 100000 mysteriously long-lived centenarians on the voters' roll, 305000 turned away for not being properly registered, and 207000 who required 'assistance' to cast their votes, all voted without exception for Tsvangirai (Chan \& Gallagher, 2017).

In an election with some 20000 domestic and international observers, and party agents at $96 \%$ of the polling stations, none could provide forensic evidence of how rigging would have changed the final result. The scale of victory could be deemed not fully credible, in terms of questions pertaining to the voters roll, but the fact of victory in itself could not be demonstrated to be implausible.

The question is whether or not there is a possible gradation from what is plausible to what is credible. Pre-election polling suggested the credibility of a Mugabe victory. The eventual size of that victory was the subject of questions to do with plausibility, but there was no coordinated effort to field a set of indices for plausibility.

\section{ZAMBIA 2016}

With a talent for exquisite euphemisms, UN Secretary-General, Ban Ki-Moon, called for these elections to be 'peaceful and orderly' - 'credible' was not at this stage mentioned nor 'free and fair'. 
Since 1991 there has been violence in Zambian elections with youthful party thugs mobilised to intimidate opposition candidates and prevent them from campaigning. Zambians have played down this aspect of their elections, partly because of the lingering doctrine from the Kenneth Kaunda era that Zambians were more peaceful than others, and also in the belief that violence in other countries is much worse (Chan 1992, pp. 188-192). In 2016 it seemed that both main parties let their youth off the leash more than ever before.

The other major aspect was that the nation's newspapers reported largely in favour of the incumbent president. The Post, the independent newspaper that supported the opposition, was forcibly shut down just before the elections, ostensibly on grounds of failing to pay its tax bills. In a land lacking the impact of electronic and social media in countries like Zimbabwe and South Africa, there was no balance of extremes in an otherwise lacklustre press.

Both these aspects faded in significance when it came to accusations and suspicions of rigging in the electoral count. That count took three days with a very slow start, a surge, and then another slowdown at a critical point. There seemed discrepancies between Electoral Commission of Zambia announcements and the parallel vote tabulations conducted by opposition party agents. Forms for reconciling these official and unofficial counts were not available at all stations.

The contest seemed all the keener because of new requirements that the winner needed over $50 \%$ of all votes cast, rather than a simple majority. Without $50 \%$ being achieved, there would have to be a runoff between the top two candidates. This meant an incumbent could always look forward to a second chance in a runoff. It also meant that any rigging had to deliver not only a majority of the votes, but enough to avoid a runoff. Both sides had forecasts with identical conclusions: that whoever won would do so by no more than $52 \%$.

Finally, the Electoral Commission announced a 50.35 victory for President Lungu. Immediately afterwards, the Commission's results website went down. When it came back up a day later, there was reasonable congruity between its count and that of the PVTs. The official figures said that Lungu had gained 1860877 votes and Hichilema 1760347 , with other candidates far down the field (Electoral Commission of Zambia 2016).

Suspicions were focused on the secrecy of the Commission's vote verification. Whereas polling station and constituency centre counts had been open to accredited observers and party agents, the EU Election Observation Commission regretted 'that its observers do not have access to the verification of results at the national results centre, despite formal requests' (EU 2016, p. 9). Suspicions were amplified when the announcement of results slowed down just as the major urban centres were coming in. It had been opposition strategy to take its normal strongholds by a large margin, but to capture sufficient of the urban vote in Lusaka 
and the northern cities of Ndola and Kitwe (Lungu's strongholds) to prevent the incumbent from realising the full benefit of his own heartland - a strategy that failed after a brief initial success. Kabwata constituency in Lusaka is a case in point. In what should have been Lungu territory, the melting-pot effect had Hichilema run him close. If this pattern had been more widely replicated in the cities, the outcome would have been different. But for all the suspicious circumstances outlined above, as well as media bias, unreasonable exploitation of incumbency, and violence, Hichilema announced he would petition the Constitutional Court to annul the outcome. This petition failed on procedural grounds.

\section{ZIMBABWE 2018}

The circumstances of this election revolved around the fall of Robert Mugabe and the death of opposition leader, Morgan Tsvangirai. Emerson Mnangagwa sought victory as a constitutional validation of his having assumed the presidency in the wake of a (virtual) military coup. To enhance this validation, but also as part of his campaign to win economic support for an increasingly impoverished country, he invited observers from the USA, the European Union, and above all the Commonwealth, seeking with victory also to re-enter the Commonwealth with its range of political and possible economic contacts.

There were repetitions of 2013 in suspicions surrounding the voters' roll, but there was by and large freedom to campaign outside the cities. The new opposition leader, Nelson Chamisa, had however alienated sections of his own MDC party by the way in which he had secured the leadership. Even without this, the MDC performance in parliament had been lacklustre since 2013, and pre-polling figures compiled by Western embassies suggested that, while Chamisa had much support in the presidential race, the MDC had much less support in the parliamentary race.

None of the observer groups fielded secretariats outside Harare although they did seek to deploy widely, especially just before and on election day. None brought in-house computer experts although a small number of Western embassies had added such personnel to their staffs.

Even so, it was clear that Chamisa engendered a late surge in support for himself, and this took Mnangagwa's party by surprise so that, in the final results, Mnangagwa very narrowly avoided having to contest a second round against Chamisa. This is not to say Chamisa would have won any second round, but coming so close did give the sense of open possibilities. The MDC trailed far behind, by contrast, in the parliamentary contest.

Despite a range of irregularities, starting from the voters' roll, observer groups found it difficult to deny plausibility to the point of credibility for the election. There had been largely free campaigning, so the fairness of the result 
would hinge on circumstances surrounding the count. The results of the count took time but the delay was not inordinate. It was enough, however, to spark public unrest and a minor protest broke out near the headquarters of the electoral commission. In full view of many observers, including foreign journalists and photographers, the army came storming in - all guns firing - to suppress this protest. Those observers not at the scene were shown moving pictures captured by journalists from distinguished newspapers. The sound of gunfire could be heard from all the main hotels where observers were staying.

The next day at the Bronte Hotel, where the Commonwealth and Carter Center observers were staying, Nelson Chamisa sought to give a press conference. Before it could get underway, the hotel was invaded by a truckload of armoured riot police, tear gas canisters at the ready. They pushed and manhandled often elderly observers and seemed oblivious that they were being filmed and internationally broadcast in real time by the foreign journalists.

The result was that the observers consolidated their doubts about the elections and added, from their own direct experience, that it had not been peaceful.

\section{TOWARDS A NEW SET OF OBSERVATION OUTCOMES}

The following observations are based on the discussion of the elections above together with the author's observation of elections and referenda since 1980.

Firstly, elections conducted in the immediate aftermath of war and great violence. The 1980 Uganda elections are an example of the difficulties that come from war-not just within the war-torn country itself, but from external pressures to broker, even gerrymander an electoral settlement that will offer some degree of stability. In such conditions, stability becomes a greater value than democracy.

Secondly, elections which have no intention of allowing an incumbent government to be replaced - even if great public protest is directed against the result, and an external mediator works towards a compromise or coalition government, with governmental places for those who were officially 'defeated', but who probably 'won'. In such conditions, inclusivity becomes a greater value than democracy.

These suggestions are for observer groups at elections where the surrender of power is possible, if reluctant; and the test of free and fair lies in the quality and forcefulness of this reluctance.

Observation cannot be a condensed affair, nor should it be contained only within the observer group but also in its links with other observer and civic groups. A 'condensed' observation, in my mind, is one which has taken less than a month on the ground. At the very least, an advance team of experts, or those 
briefed on the constitutional, electoral, and political affairs of the country should be in place as a reconnaissance unit a month before polling day. Most observer groups now contain such experts, but they are called upon to answer questions as they arise in the final phases of observation, and not to present to the observers their own latest observations gleaned from time in the country.

The reconnaissance team also needs to be energetic and mobile, traversing the country. At the 2010 Sudanese elections, while assigned to areas of South Sudan still enjoying forms of contention or war-readiness, we took a simple executive decision: if we saw an EU, AU, or Carter Center car, we weren't out far enough. We never saw an Arab League car. We went until there were no other observers for miles around - but then asked 'why?'

\section{To be Free and Fair}

In addition to on site presence before polling day, these would be the requirements for an observer group to declare elections 'free and fair':

1. A clear moratorium on violence by all organised contenders. This has to be sustained all the way through the counting process.

2. No hinderance on physical campaigning, and state security has been made available to all organised contenders for their major rallies.

3. All media has been free to report on the election, even if that means a moratorium on debt owed by any section of the media.

4. That media is comprehensive, i.e. it should include access to broadcasting including vernacular radio.

5. The incumbent government does not make use of incumbency during the campaign, e.g. by launching or opening huge public works as a campaigning strategy, or by utilising state funding for its own campaign while denying exactly such funding to organised challengers.

6. Polling day conforms to the now established protocols of access and facilitation and secrecy.

7. Procedures are in place at each polling station to agree official and PVT final figures and for these to be transmitted to electoral commissions in a recorded manner.

8. All electoral commission verification procedures are witnessed by observers.

9. The observers detect no untoward variations between sustained opinion polling before the elections, voting patterns in the previous election, voting patterns for parliamentary and presidential can- 
didates, and voting patterns in adjacent densely populated urban constituencies, without clear margins of error being explicated, or other decisive characteristics taken into account.

10. There is no interruption to the counting process, i.e. once started, it is continuous, observable and gives no pause for tampering or adjustment.

\section{To be Peaceful and Credible}

1. 'Peaceful' relates to the same condition, 1 and 2 above, pertaining to 'Free and Fair'.

2. Basically, 'Peaceful and Credible' relates to conditions, above, 3 to 6, about conditions of campaigning, but it is a judgement call as to their being not 'good' but 'good enough', i.e. campaigning met difficulties, especially for opposition candidates, but on a by-andlarge basis, campaigns were able to be nationally conducted and a clear opposition message could be put across.

3. However, the real test of 'credibility' lies in 7 to 10 , above, to do with counting, i.e. it was not seamless, not always continuous, and there were lacunae in opportunities for observation; but, by-and-large, margins of error allowed for a not fully perfect result to be regarded as 'credible'. The rationale behind 'margins of error' needs to be made clear by the observer group.

\section{To be Plausible but Problematic}

This judgement resides primarily in the tests for 7 to10, above, i.e. the margins of error are larger than satisfactory, larger than fully explicable - but are conditionally explicable - and it is for the observer group to make this explication clear and how it was utilised in its final judgement.

\section{To be Not Fully Plausible}

When the conditions outlined in 'conditionally explicable' deviate from full plausibility, i.e. the key inference here is of intervention of a sustained and planned and calculated manner in key stages of the counting and verification process.

\section{To be Implausible}

What happened in 2016 in Gabon provides a key example where, after a critical pause in the counting and announcement of results, the president was returned 
by a key constituency where turnout was $20 \%$ higher than national turnout, and voting in favour of the president was similarly higher than in any other part of the country. This delayed, sudden, decisive variation is grounds for implausibility.

\section{To be Unacceptable}

When both campaigning and counting were subject to so many observable interventions of an untoward nature that no credibility or plausibility attaches to the outcome. This should have been the verdict of observation of the 2008 elections over two rounds in Zimbabwe, despite efforts to render the final results of the first round in a sense 'plausible'.

The term 'not conforming to international standards', in regular use, should be amplified by the addition of one of these last three categories.

\section{CONCLUSION}

Election observation has become mired in the conduct of polling day itself and shortly thereafter, but observers have not always been available in the country to note a full swathe of campaign conduct. Above all, concentration on all aspects of counting, and testing of the count as outlined above, has not been sufficiently robust at all recent African elections. Insofar as African governments now prepare almost immaculate polling days - feats of organisation involving thousands of polling stations - election observation has accomplished something. Observation still needs to consider a more extended presence during campaigning. But, importantly, it must address its own key next stage, which involves the forensics of observing and testing the count. What does this mean? In summary it should involve testing the electoral commission's count as follows:

1. Against PVTs.

2. Against opinion polls, patterns from previous elections; results in adjacent constituencies; and the concerns of NGOs who also fielded observers.

3. Monitoring the transmission process as agreed local totals reach central points. How is this done? If manually, against what parallel electronic process?

4. The count at each stage should be tested against computer projections from when the last batch of results came in, calibrated against a range of different conditions, types of constituency, and electoral histories and patterns.

5. Testing the robustness of data assemblage in the central verification process and observing all aspects and moments of the verification. 
Given that specialist consultant firms are rumoured to adjust results in a credible, or at least plausible way, observers require the technological and forensic skills to play the 'adjusters', not merely naked 'riggers', at their own game. Whether or not these adjusters exist observer capacity to apply computerised forensic tests will at least delay the advent of any such manipulation in the future - or at least make their task much harder. In short, the protection of electoral democracy today and tomorrow requires sharp observation skills using contemporary technology.

There can be upwards of 20000 observers at African elections, although more than double that number were at the very large 2019 Democratic Republic of Congo elections. The bulk of these will be local civic action group observers. It seems a large number but, in an election of e.g. 5000 polling stations, it means an average attendance at each station of four observers at any one time; if they come from disparate groups, their observations may also be disparate, as there is no means to coordinate or harmonise verdicts. In any case, their attendance on election day will be to compile checklists of good polling station administration and conduct.

The number involved in observation is greater in many cases, as interested countries, e.g. those with large aid programmes to the country concerned, will have many volunteers from their own civic action, think tank, and advocacy groups from their own country. While not accredited as observers, they will accompany selected local observer groups and will report to their own embassy, where the political officers will certainly be number crunching the observed results. Thus, both the election and observation will be the subject of parallel observation and assessment not intended for publication, but for reportage to government offices back home. Official observer groups should have number crunching capacity themselves, especially those from large international organisations, such as the AU.

\section{CODA}

Is the continual observation of elections over many years in many countries dispiriting? My personal experience is that I no longer enjoy it and would rather not do it anymore. But, as a private observer, I have my own methodology and part of that is to observe election day in the slums of the great cities. I lived in Kliptown, the poorest part of Soweto, for the last two South African elections; I was in George, the poorest part of Lusaka for the 2016 Zambian elections. It is for the people who must live with the results of election after election that elections should be held in an honest, free and fair manner. A paper like this one, which outlines a gradation downwards of categories from 'free and fair', indicates a harsh realisation that the poor will not be able to vote their way out of wretchedness. 


\section{Acknowledgement}

An earlier version of this article appeared in Democracy in Africa, 28 January 2017.

\section{- REFERENCES}

Ban Ki Moon 2013, 'All Kenyans must work to ensure upcoming polls are peaceful and credible', UN News, <http://www.un.org/apps/news/story. asp?NewsID $=44243 \#$.VU5FGViko

Ban Ki Moon 2016, Lusaka Times 16 August, <https://www.lusakatimes. com/2016/08/16/un-secretary-general-congratulates-zambia-peacefulelections $/>$

Bloomfield, S 2008, <http: / www.independent.co.uk/news/world/africa/kibaki-stole-kenyan-election-through-vote-rigging-and-fraud-772349.html>.

Booysen, S 2012, Change and 'New' Politics in Zimbabwe, Freedom House, Harare. $<$ https://www.freedomhouse.org/ sites/default/ files/Change $\% 20$ and $\% 20$ New\%20Politics\%20in\%20Zimbabwe.pdf>.

Chan, S 1988, The Commonwealth in World Politics: A Study of International Action 1965 to 1985, Lester Crook, London.

Chan, S 1985, The Commonwealth Observer Group in Zimbabwe, Mambo, Gweru.

Chan, S 1992, Kaunda and Southern Africa: Image and Reality in Foreign Policy, I.B. Tauris, London.

Chan, S \& Gallagher, J 2017, Why Mugabe Won: The 2013 elections in Zimbabwe and their aftermath, Cambridge University Press, Cambridge.

Chan, $S$ 2008, 'The Tragedy of Tsvangirai', Prospect, August.

Chan, S \& Gallagher, J 2017, Why Mugabe Won: The 2013 elections in Zimbabwe and their aftermath, Cambridge University Press, Cambridge.

Cheeseman, N 2015, Democracy in Africa: Successes, Failures, and the Struggle for Political Reform, Cambridge University Press, Cambridge.

Committee for Free and Fair Elections in Cambodia (COMFREL) 2008, <http: / / www.comfrel.org/eng/components / com_mypublications / files / 16636312248089632008_COMFREL_PVT_Report.pdf>

Commonwealth Secretariat 1980, Southern Rhodesia elections, February, 1980: report of the Commonwealth Observer group on elections leading to independent Zimbabwe, Commonwealth Secretariat, London.

Electoral Commission of Zambia 2016, <https://elections.org.zm/news/ tag/2016-general-elections / >.

European Union Election Observation Mission 2017, Kenya: Executive summary $<$ http:/ / eeas.europa.eu/eueom/missions / 2007/kenya/index_en.htm>. 
European Union Election Observation Mission 2002, Sierra Leone presidential and parliamentary elections, 14th May 2002: final report.

European Union Election Observation Mission 2016, Zambia: Preliminary Statement, 'Generally well-administered and peaceful election day marred by systematic bias in state media and restrictions on the campaign, Lusaka, 13 August.

Kabeireho, J 2008, 'How UPC "rigged" the 1980 elections', Observer 10 December, <https: / / www.observer.ug/ component/ content/ article?id=1855:howupc-rigged-the-1980-elections $>$.

Kelley, KJ 2008, 'US-funded exit poll says Raila won elections', The Daily Nation, 10 July.

Moore, D 2008, 'An Academic's Journalism in the Zimbabwean Interregnum', Association of Concerned African Scholars Bulletin 79: Special issue on Zimbabwe crisis, Spring 2008, no. 79, <http://concernedafricascholars. org/bulletin/issue79/moore/>

Mugabe, F 2016 'Observers contradict themselves on 1980 poll', Daily Monitor <http: / / www.monitor.co.ug / Magazines / PeoplePower / Observerscontradict-themselves-on-1980-poll/ 689844-3104412-y82yeqz/index. $\mathrm{html}>$.

Mugabe, F 2016, 'Election should not have been held says former EC boss', Monitor, 2 January, <http://www.monitor.co.ug/News/Insight/1980-electionsformer-EC-boss / 688338-3018004-34y77qz/index.html>.

Muisyo, V 2016, 'Gabon: Civil society rolls out app to counter election rigging', Africanews 0608 2016, <http:/ / www.africanews.com/2016/08/06/gaboncivil-society-rolls-out-app-to-counter-election-rigging/ > .

Namusoke, E 2016, ‘Observing Uganda's 2016 Presidential Election', Institute of Commonwealth Studies, <https://commonwealth-opinion.blogs.sas. ac.uk/2016/observing-ugandas-2016-presidential-election/>.

Willis, J, Lynch, G \& Cheeseman, N 2017, 'A valid electoral exercise: Uganda's 1980 election and the rise of international election observation', Comparative Studies in Society and History, vol 59, no 1, pp. 211-238. 


\title{
ELECTORAL POLITICS AND POLITICAL TRANSITION IN POST-WAR ANGOLA \\ Progress, Problems and Prospects
}

\begin{abstract}
Albano Agostinho Troco
Albano Agostinho Troco is a PhD candidate, Department of Political Studies, University of the Witwatersrand, Johannesburg
\end{abstract}

\begin{abstract}
The southern African nation of Angola was included in the third wave of democratisation which began rolling over the African continent in the late 1980s. Structural political and economic reforms, including multiparty elections, were introduced in Angola as part of a peace settlement designed to set the country on a path to effective democratisation. However, the resumption of the armed conflict in the aftermath of the country's founding elections in 1992 blocked Angola's transition towards the consolidation of a multiparty democratic dispensation. The end of the civil war in 2002 renewed hopes for normal democratic development through a return to electoral politics. Building on the conception of elections as both instruments of democracy and tools of authoritarian rule, this article examines the progress, problems and prospects for democratisation brought about by the resumption of electoral politics in post-war Angola. The analysis of the evidence gathered from qualitative secondary sources suggests that, since the end of the war in 2002, Angola has seen the establishment of electoral hegemony. The MPLA has total dominance of not only the electoral process -its rules, their implementation and adjudication - but also of electoral results, allowing the winner to rule unchallenged. This has subsequently been used to engender other types of political domination, including constitutional and central government hegemony, thus ensuring regime entrenchment.
\end{abstract}

Keywords: post-war Angola, elections, electoral politics, electoral authoritarianism in Africa, democratisation 


\section{INTRODUCTION}

The late 1980s and early 1990s witnessed massive political changes in sub-Saharan Africa, as personal dictatorships, one-party states and military regimes began to fall under the pressure of an emerging trend towards pluralist politics and multiparty elections. The changes came about as a result of both endogenous factors, such as popular calls for democratic rule; and exogenous factors, particularly the collapse of the Soviet Union and the end of the Cold War, which were part of a global phenomenon dubbed 'the third wave of democratization' (Huntington 1991). As one country after another held its 'founding elections', these events were described as the beginning of great 'democratic experiments in Africa' (Bratton \& van de Walle 1997).

The optimism generated by the introduction, in some cases re-introduction of multiparty politics on the continent, was captured in the terminology used to describe the political changes taking place on the continent: 'political earthquake' (Mbaku \& Ihonvbere 1998, p.1), 'Africa's second independence' (Ake 2000) and 'tectonic movements in African politics' (Bratton et al. 2005, p.14). However, assessments of these developments reveal a continent that is home to diverse political configurations. These range from liberal democracies and veiled personal dictatorships to 'situations in which elements of democracy and liberal politics operate in contexts where neo-patrimonialism and authoritarian tendencies also remain' (van de Walle 2002, p.66). In particular, the expansion of multiparty elections has given rise to the emergence of dominant-party systems and the prevalence of electoral authoritarian regimes in the politics of contemporary Africa.

Angola was part of the third wave of democratisation that began to roll over sub-Saharan Africa in the late 1980s. Substantial political and economic reforms, including multiparty elections, were introduced in the country as part of a peace settlement designed to consolidate strife-free political competition and set the country on a path to democracy. However, the resumption of the civil war in the aftermath of Angola's founding elections in 1992 blocked the country's trajectory towards the consolidation of a democratic dispensation, leaving it in 'an ambiguous state of transition' (Hodges 2004, p. 47). ${ }^{1}$ The end of the armed conflict in 2002 renewed hopes for normal democratic development through a return to electoral politics.

This study examines the extent to which this expectation has been fulfilled, and the role of electoral politics in the political transition of post-war Angola, that is in the $21^{\text {st }}$ century. More specifically, the study explores the three general

1 Although the democratic reforms introduced in the months leading up to the 1992 elections were not reversed, there were severe restrictions placed on their application. 
elections that have been held in the country since the end of the civil war, namely the 2008, 2012 and 2017 electoral processes, so as to ascertain their impact on the development of the democratisation process in the country. The focus is on the progress, problems and prospects for this transition to a more democratic dispensation between 2008 and 2017. The study is informed by the textual analysis of data gathered from secondary sources, such as books, peer-reviewed articles, newspapers, legislation and reports, and builds on two major theoretical assumptions: Firstly, that elections can be used both as 'instruments of democracy' (Powell 2000) and as 'tools of authoritarian rule' (Schedler 2015). Secondly, that regime transitions are open-ended processes, leading to the emergence of a democratic dispensation or a renewed form of authoritarian rule (Carothers 2002).

The analysis starts with an examination of the ambiguous character of elections as both instruments and tools of democracy and moves to explore the progress Angola has made towards democratisation. This is followed by a reflection on the challenges to the democratic process, culminating with an analysis of the prospects for democratisation in post-war Angola.

\section{ELECTIONS AS BOTH INSTRUMENTS OF DEMOCRACY AND TOOLS OF AUTHORITARIAN RULE}

In commonplace language, the word elections refers to mechanisms designed to choose representatives to perform specific duties for a group through the act of voting. In the realm of politics, elections represent a means to determine the collective decision of the citizenry regarding who should govern. This view is encapsulated in the definition of elections as 'processes by which citizens choose a person to represent them in public office, or by which citizens accept or reject political propositions' (Scott 2007, p.123).

Although elections were not the preferred tool for selecting public officials in ancient Athens, the world's first known democracy, they have become the defining institutional element of democracy in contemporary societies. Through elections the essence of democracy, that is self-rule of the people, is actualised in contemporary times. This is because of the impracticalities of practicing direct democracy in today's densely populated and territorially large political communities where elections have emerged as the primary institutional mechanism for translating people's power to rule into government power through elected representatives.

Besides enabling the delegation of political representation, elections make fundamental contributions to the sustenance and consolidation of democratic governance. Firstly, elections confer legitimacy on the political system and government. In the contemporary world, where democracy is considered the 
only acceptable form of government, it is difficult for a government to claim to be democratic if it does not hold elections. This is also a strong argument for the legitimacy of any political system that is legitimate because it is democratic, and democratic because it holds elections' (Katz 1997, p.102). Secondly, electoral processes contribute to the institutionalisation of peaceful access to political power by allowing ordinary citizens to make themselves available for political office or to participate in the selection of political leaders. Thirdly, the regular occurrence of elections turns it into a practical mechanism to make government accountable to the people. Electoral processes provide voters with the opportunity to punish elected representatives should they fail to fulfil the aspirations of the citizenry, or to keep them in their positions if the electorate approve of their performance.

Fourthly, elections foster active popular involvement in public life. During campaign periods, alternative visions of society are put forward, with candidates trying to convince voters of their suitability and citizens trying to decide between different proposals. Furthermore, electoral campaigns inspire citizens to take a more active public role by listening to debates, expressing demands, proposing solutions to problems and standing for office. These culminate with voting, which is an act of direct participation in public decision-making. Lastly, elections give voters decision-making power over the policy decisions of government. This goal is accomplished by encouraging public officials to be responsive to the public and by giving citizens a direct role in government policy-making through direct participation in referenda and legislative initiatives (Medvic 2013, p.12).

However, elections must meet the criteria of freedom and fairness to pass as democratic. Elklit and Svensson (1997, p.40) clarify the meaning of these two constitutive qualities of democratic elections, noting that 'freedom entails the right and the opportunity to choose one thing over the other', while fairness 'involves both regularity (the unbiased application of rules) and reasonableness (the not-too-unequal distribution of relevant resources among competitors)'. Along the same lines, Levitsky and Way (2010, p.7) explain that elections are free 'in the sense that there is virtually no fraud or intimidation of voters' and fair 'in the sense that opposition parties campaign on relatively even footing: they are not subject to repression or harassment, and they are not systematically denied access to the media or other critical resources'. In brief, an election is free when voters can choose candidates, political parties and policies without any form of undue influence, coercion or intimidation; and fair when contenders are treated equally, and the electoral contest takes place on a level playing field, that is when everyone has the same chance of succeeding.

Without these conditions to guarantee the freedom and fairness of electoral processes, elections lack their democratic substance and content, leaving only their form, the procedure. When this happens, elections cease to be 'instruments 
of democracy' (Powell 2000) becoming instead 'tools of authoritarian rule' (Schedler 2015). This has been the case in many countries in post-Cold War Latin America, Eurasia and Africa where political elites have adopted multiparty electoral competition, while manipulating electoral processes in order to ensure political survival. This state of affairs places these countries in the broad category of electoral authoritarian regimes as 'the idea of democratic self-government is incompatible with electoral farces' (Schedler 2002, p.37).

\section{PROGRESS}

The Angolan polity has seen great changes since the end of the armed conflict in 2002. The most important of these changes is unquestionably the arrival of peace, which acts as a precondition for the development of any political community, and in the case of Angola has led to a resumption of the democratisation process. The following examples illustrate the progress that the country has made towards the development of a truly democratic political system. These include the organisation of three consecutive electoral processes, the promulgation of a brand-new constitution, and the schedule of the country's long-awaited first local elections for 2020.

Since the end of their civil war Angolans have been to the polls on three occasions, namely in 2008, 2012 and 2017. Several political parties participated in these elections, which confirmed the electoral domination of the ruling Popular Movement for the Liberation of Angola (MPLA). The 2017 electoral process is particularly important because of 'the politics of presidential succession' (Pearce et al. 2018). After almost four decades in power, President dos Santos decided not to stand again for re-election, thus paving the way for a new head of state, President João Lourenço.

Angola's post-war era has also seen the promulgation of a new constitution. Prior to the approval of the new constitution in 2010, a constitutional law (enacted in 1991 and revised in 1992) regulated all public and private affairs in the Angolan polity. The document had a provisional character, as at the time of its approval it had been expected that a new constitution would be negotiated by the legislature emerging from the country's first multiparty elections held in 1992. However, this did not happen due to the resumption of the civil war in the aftermath of the elections. Consequently, the approval of a new constitution in 2010 brought this protracted constitution-making process to a conclusion.

Despite the introduction of major reforms such as the abolition of direct presidential elections, the new constitution reaffirmed provisions found in previous constitutional documents. One such provision relates to the institutionalisation of the autarquias locais or elected local government bodies comprising an assembly 
with decision-making powers, a collegiate executive body and a president (arts. 217-222, CRA 2010). At present, Angola has no locally elected officials. All state officials at the local level (province, municipality and districts) are appointed by the central government. After successive delays, the first local elections in the history of the country are now scheduled for 2020.

\section{PROBLEMS}

This section investigates the main challenges to democratisation in post-war Angola in a critical examination of the major political transformations in the country since the end of the war. These comprise electoral politics, the constitutional reform process, and the institutionalisation of local elections.

\section{The Nature of Electoral Politics}

The advent of peace revived calls for a return to electoral politics in Angola. In particular, there was a need for renewed electoral mandate at the apex of the central institutions of the state, the National Assembly (parliament) and the Head of State, which had been suspended as a result of the war effort. After successive delays, Angola held its first legislative elections since the end of the civil war on 5-6 September 2008. These have been followed by two consecutive general elections held on 31 August 2012 and 23 August 2017, respectively.

The MPLA has been in power in Angola since the country's independence from Portugal on 11 November 1975. It has won the three electoral contests with overwhelming majorities of $81.6 \%$ of the votes in $2008,71.8 \%$ in 2012 and $61.1 \%$ in 2017. These outstanding results mean that the ruling party has successively won 191, 175 and 150 seats in a 220-seat parliament, investing it with a supermajority that allows the party to govern alone and implement any structural reform uncontested, including changing the country's constitution. In contrast, opposition parties as a whole have gained a mere 18.4, 28.2 and 38.9 percent of the votes in the 2008, 2012 and 2017 elections respectively (Matsimbe \& Domingos 2018). Although they have increased their share of parliamentary seats from 29 to 45 and then 70 seats in a 220-seat parliament, opposition parties remain minor players in the Angolan political system.

The abovementioned electoral results not only indicate the non-competitive nature of the Angolan political system but also the configuration of the party system, which has the characteristics of a dominant-party system and works as a de facto one-party state. Dominant-party systems are defined as states where multiparty politics are constitutionally and legally endorsed, but where in practice only one party dominates the political system to the exclusion of other political 
forces (Bogaards 2004). This type of political configuration tends to impact negatively on the overall performance expected from an established democratic state since they are not sufficiently separated from state institutions. In other words, in transitional settings, dominant-party systems tend to be hostile to meaningful democratisation because they often blur the lines between the state, the ruling party and government.

Although national and international observers have declared Angola's postwar elections to be overall free and fair, the electoral hegemony of the MPLA continues to derive from its dominant-party status. Control over state institutions and resources have often been used to manage electoral processes, shape the electoral playing field and ultimately deliver resounding victories. However, this does not in any way exclude the failures and weaknesses of opposition parties, which suffer from a series of structural and organisational problems.

For instance, there have been negative perceptions about the credibility of the voters' registration process and the integrity of the voters' roll. These tasks are carried out by government (through the Ministry of Territorial Administration) under the supervision of the National Electoral Commission (CNE). This institutional arrangement is particularly problematic in the case of Angola, which is dominated by a public administration that is still learning to practice the culture of bureaucratic neutrality. In the Angolan context, this arrangement means that despite being a contestant in the electoral game, the ruling party can manipulate the composition of the electorate through its control over the compilation of the voters' roll. This seems to have been the case in 2012 when almost two million voters were prevented from casting their votes. Official records showed that voters were registered to vote in polling stations located far away from where they lived, sometimes even a different municipality or province altogether. The government's explanation noted that the voters in question had not updated their registration (COE 2012, p.8). The opposition, and in particular the leader of the main opposition party, stated publicly that those voters had been the victims of 'a structured and well-planned program of manipulation of the voters' registration data orchestrated by the government'.2

The impartiality of the institution responsible for the administration of electoral procedures, the $\mathrm{CNE}$, is also questionable. According to the constitution, the CNE is an 'independent administrative body' (art. 107, CRA 2010). However, this administrative independence (meaning that the CNE is not incorporated in a ministry or other government department) does not extend to the way the entity operates. This is so because of the legal provisions for the appointment

2 See: http://www.club-k.net/index.php?option=com_content\&view=article\&id=12877:i ntegra-do-discurso-do-lider-da-unita-em-reacao-aos-resultados-das-eleicoes-de-31-deagosto\&catid=11\&Itemid=1072\&lang=pt [viewed 14 April 2018]. 
of its members, resulting in a partisan body strongly dominated by the ruling party. Accordingly, the CNE comprises seventeen commissioners eligible for up to two five-year terms and includes the president (a judge chosen and appointed by the Supreme Council of the Judiciary) together with sixteen commissioners nominated by political parties and party coalitions according to their electoral strength. After being nominated by the parties, commissioners are officially appointed in the National Assembly by an absolute majority of votes (art.143, Law 36/2011). The outcome of the elections determines the number of commissioners a party is entitled to nominate. The outcome of the 2008 elections resulted in the following allocation for the 2012 elections: nine commissioners for the MPLA, three for National Union for the Total Independence of Angola (UNITA), two for the Social Renewal Party (PRS), and one for the National Front for the Liberation of Angola (FNLA) and New Democracy-Electoral Union (ND-UE), respectively (art.209, Law 36/2011). The same configuration is replicated down to the CNE's provincial and municipal structures. The outcome of the 2012 elections ensured that the MPLA was entitled to appoint the same number of commissioners in 2017, which effectively ensures that the ruling party enjoys almost complete control over the electoral commission.

The partisan character of the CNE has turned the electoral administration body into a miniature replica of the National Assembly, where the ruling party dominates with the required majority to approve or block any decision it deems fit for its political agenda. This situation is particularly challenging since in the Angolan case, the electoral commission doubles as an electoral court, working as a first instance court in the settlement of electoral disputes.

Consequently, the electoral commission has often been at the centre of major election-related controversies in the country. For instance, during the 2008 elections, the CNE was accused of preventing the accreditation of national observers from independent civil society groups (HRW 2009, p.25). In the months leading up to the 2012 elections, the head of the CNE, a high-ranking MPLA official, was forced to resign after the Supreme Court found her re-appointment to be unlawful. However, successive attempts by opposition parties to invalidate the decisions she made during her contentious tenure (roughly three months before polling day) were unsuccessful. More recently, during the 2017 electoral process, opposition parties accused the CNE of hiring INDRA and SINFIC without following proper procedure. The process leading up to the selection of the two companies was shrouded in mystery, suggesting a previous agreement between the commission and the companies. The events took place in a context where INDRA and SINFIC stood accused of helping to rig previous elections and consequently were not trusted by opposition parties. In the end, the CNE's controversial decision prevailed and the two companies went on supplying the electoral logistics and computer programs for the elections. 
In post-war Angola, the electoral playing field is often skewed in favour of the ruling party, resulting in unfair competition. Having been in power for more than four decades, the MPLA has absolute control over state resources. During campaign periods, the public administration, vehicles, state media and other state resources are deployed at the service of the ruling party and there are massive unveilings of public works across the country. Government officials, acting as party officials, unveil these public works which are paraded as MPLA's achievements. Public servants are often forced to attend MPLA's rallies for fear of losing their jobs if they fail to comply. It was reported in the 2012 elections that there was widespread fear amongst public servants that they would lose their jobs if they voted for any party other than the MPLA (OPSA 2012, p.5).

This uneven playing field has also been made manifest in terms of access to finances. Although all parties cleared to run in the elections are entitled to an equal amount of public funding, the MPLA often dwarfs those sums. For instance, in the 2008 electoral process all parties received the equivalent of $\$ 1.2$ million from the government to fund their campaign. However, the cost of the ruling party's campaign was estimated at around \$300 million. Analysts have pointed out that the amount was probably the result of donations from Sonangol (the National Oil Company) and Endiama (the National Diamond Company), in clear violation of regulations preventing political parties from accepting donations from public companies and foreign entities (Roque 2009, p.142). In recent times, it has emerged that the ruling party's campaign in 2012 benefited from US $\$ 50$ million paid for by the Brazilian Construction Company Odebrecht in clear violation of the electoral law, which bans the acceptance of funds from foreign entities (art.80, Law 36/11). ${ }^{3}$

Media access is another area where the odds are tilted towards the ruling party because of the configuration of the media sector in Angola, which is controlled by the MPLA. State-run media outlets dominate the media sector - the National Television Broadcasting (TPA); the National Radio Broadcasting (RNA); and Journal de Angola (a daily newspaper). People close to the ruling party own most private media outlets, giving the illusion of media pluralism (Faria 2013). Most of the population is prevented from accessing alternative sources of information because of regulations that grant state monopoly over national radio and television broadcasting. Electoral legislation provides for equal media coverage during the official 30-day campaign period for reports on electoral activities (ten minutes on the national radio broadcaster and five minutes on television); but outside these allotted times the media tends to focus disproportionally on pro-ruling party and pro-government reporting.

3 UNITA acusa MPLA de receber financiamento externo nas eleições de 2012 em Angola: https: / / www.dn.pt/lusa/interior/ unita-acusa-mpla-de-receber-financiamento-externo-naseleicoes-de-2012-em-angola-8595831.html [viewed 18 April 2018]. 
Finally, there have been major controversies around vote counting, and opposition parties have repeatedly claimed that their representatives are excluded from the counting centres. As a result, the three electoral processes held in postwar Angola have been settled in court. The most widely reported case in the media took place during the 2017 electoral process when CNE commissioners nominated by opposition parties held a press conference to distance themselves from the provisional results. Subsequently, opposition parties, with the exception of the National Patriotic Alliance (APN), rejected the provisional results, claiming that the vote-counting process did not follow proper procedure. This led to the unfolding of a pattern observed in 2008 and 2012 where the MPLA-dominated CNE would dismiss the contestations and the Constitutional Court (the highest court of appeal in the settlement of electoral disputes) would uphold the decisions taken by the electoral commission.

It is thus evident that in the post-war period the MPLA has resorted to control over the state and its structures to attain electoral hegemony. This view is summed up in the assertion by Pearce et al. (2018, p.152), referring to the 2017 elections, that 'it is not as a party that the MPLA goes to the polls, but as a partystate'. Electoral outcomes are then used to engender other types of domination, such as approving a self-serving constitution (constitutional hegemony) and delay the implementation of elected local government bodies (central government hegemony). These strategies not only consolidate the power of the ruling elite in the short term but also ensure the party's continued control over the Angolan polity in the long run.

\section{The Atypical Constitution}

In the aftermath of the 2008 elections, the MPLA put the presidential and local elections on hold, conditional on the approval of a new constitution. In this regard, this study suggests that President Dos Santos and the ruling party built on the 2008 electoral victory in order to consolidate their hegemonic control over the Angolan political system through the constitution-making process concluded in 2010 - the MPLA by pre-empting the possibility of losing power through elections, and Dos Santos by cementing his personal power and position as the dominant figure in Angolan politics. This argument has theoretical support from the idea that in the current 'era of electoral authoritarianism' (Morse 2012) constitutional change is one of the many tactics that rulers use to retain and maintain power (D’Anieri 2013, p.6).

On 5 February 2010, President Dos Santos promulgated the Constitution of the Republic of Angola. This followed an approval of the document by the National Assembly two weeks earlier. The MPLA, PRS and the ND-UE voted 
in favour of the document, the FNLA abstained, while UNITA parliamentarians walked out of parliament in protest. According to Ms. Alda Sachiambo, leader of UNITA's parliamentary caucus at the time, 'January 21 will be remembered as a day of national mourning for Angolan democrats because it marks the consummation of a coup against democracy and the sovereignty of the Angolan people perpetrated by the MPLA, the enemy of the people' (O Publico, 21 January 2010).

More important, for the purposes of this paper, is the 'map of power' encapsulated in the new constitution. Accordingly, the Angolan constitution exemplifies the phenomenon of 'imperial presidency' as it endows the president of the republic with extensive executive powers in the absence of meaningful mechanisms checks and balances (Okoth-Ogendo 1991, p.13). For instance, the president of the Republic is the head of state, holder of executive power and the commander-in-chief of the armed forces (art. 108, CRA 2010). Ministers serve at the pleasure of the president assisting him in fulfilling his executive powers (art. 108, CRA 2010). Technically, there is no government but the president who is the holder of all executive powers (Titular do poder executive, in Portuguese).

In addition to the considerable legislative powers which the president shares with parliament, the president has the prerogative to appoint the presiding and deputy presiding judges of all the highest courts in the country (Constitutional, Supreme, Auditors and the Supreme Military Courts), to appoint and dismiss the attorney general, the deputy-attorney general and the military prosecutors of the Supreme Military Court (art. 119, CRA 2010). These provisions not only compromise the independence of the judiciary and the democratic principle of separation of powers, but give pre-eminence to executive power.

The Angolan constitution, however, is not the only constitution in the world that grants extensive powers to the president; in fact, many presidential systems make similar provisions. However, the peculiarity of the Angolan constitutional order, which runs counter to modern liberal constitutionalism, is the absence of a system of checks and balances to regulate the exercise of presidential power. For instance, the constitution does not provide for a parliamentary vote of no confidence in the president. It also prevents parliament from summoning ministers or other 'auxiliaries of the holder of executive power' without the president's consent (Constitutional Court Ruling 319/2013). This effectively results in a system with minimal or no executive accountability to parliament. Nonetheless, the president may resign for political reasons and should this happen, parliament is automatically dissolved and early elections are called (art. 128, CRA 2010).

Despite the large concentration of powers in the executive branch, the constitution does not provide for the direct election of the president. The constitution clearly states that, 'the individual heading the national list of the political party or coalition of political parties that receives most votes in the general elections shall 
be elected President of the Republic and Head of the Executive' (art.109.1, CRA 2010). This provision has at least three major implications: it fuses presidential and legislative elections, preventing voters from making different choices between a presidential candidate and parliamentary representation; it shields the top executive officer and his deputy from the direct judgment of the voters; and it prevents independent candidates from running for the presidency, thus forcing them to align themselves with a party or a coalition of parties cleared to run in the general elections.

This configuration of power has given rise to some interesting debates regarding the system of government outlined in the Angolan constitution. Although the Angolan system of government has officially been described as 'presidential-parliamentary' ${ }^{4}$, it is essentially sui generis because it does not fit within any of the classical categories (parliamentary, presidential and semi-presidential systems). Attempts at classifications by eminent Portuguesespeaking legal scholars have yielded various conclusions, including a 'hyperpresidential regime' (Vital Moreira cited in Pereira 2013, p.6), a case of 'extreme presidentialism' (Pestana 2011) and a 'simple representative government' (Miranda 2010). Alexandrino (2013, p.13) captures the Angolan reality with a concise clarification, that the system of government outlined in the Constitution of the Republic of Angola is a specifically Angolan system (that is, it is an atypical system), characterized by a de facto presidentialism and power personalization, within a multiparty framework with a hegemonic party'.

The adoption of a highly presidentialist constitution in Angola speaks to the persistence of the logic of 'personal rule' in Africa (Jackson \& Rosberg 1982; Hyden 2006, p. 95). In fact, the constitution has merely translated into law the political reality of President Dos Santos's pre-eminence in the Angolan political system, further consolidating his personal powers. This leads to questions about how President Dos Santos managed to attain such constitutionally sanctioned powers. The answer to this question seems to lie in the remarkably long tenure of his presidency and shrewd political manoeuvring during the extraordinary circumstance of a raging civil war.

To begin with, President Dos Santos was one of the longest-serving leaders in Africa. He had been in power for almost three decades when the constitution was adopted. This longevity provided him with enough temporal latitude to consolidate a parallel system of power, which functioned alongside centres of

4 This terminology is misleading. In the Angolan context, the system of government was termed 'presidential' in reference to the preeminence of the president in the structure of government (often (mis)-using the American case to illustrate the presidential nature of the system) and 'parliamentary' in relation to the mode of electing/selecting the head of state (indirectly in parliament with references being made to the South African case). 
power such as state institutions and the MPLA. The parallel system consisted of a large presidential bureaucracy comprising an office for civilian affairs and an office for military affairs. This administrative structure held a preeminent position in the definition of all major policies in the country. The engine of the parallel system was kept running by funds from Sonangol, the national oil company and the main source of Angola's state revenues. President dos Santos' control over Sonangol granted him direct access to petrodollars, which were used to reward and co-opt different groups and individuals within the state and society at large, including influential politicians, military personnel and family members (Soares de Oliveira 2015).

In addition, President Dos Santos' consolidated his personal powers against the backdrop of the civil war. In these exceptional circumstances, the centralisation of power in the presidency took place at the expense of the MPLA, the party over which Dos Santos had presided. For example, he remained in office despite the inconclusive nature of Angola's first presidential elections in 1992. Furthermore, government continued to function along presidential lines despite the constitutional provision for a semi-presidential system, which required the president and the prime minister to share executive powers. The relationship between these two entities has always been tense, reaching a peak after the president failed to appoint a prime minister in 1999. On that occasion, President Dos Santos decided to approach the Supreme Court to clarify the position of head of government. After the court found in his favour and recognised him as the head of government, the president abstained from filling the constitutionally sanctioned office of the prime minister, arrogating all the powers attached to that position. This made him de facto head of state and head of government.

The post-war period also elicited new political manoeuvres: in 2005, President Dos Santos approached the Supreme Court to pronounce on his eligibility to run for the presidency. This was in the context of the approval of the new Electoral Law, which established that the position of president of the Republic should be held only for two consecutive or three non-consecutive terms (art. 17/d, Law 06/05). The court ruled that the president had been exercising his duties in a context of constitutional abnormality, resulting from the non-conclusion of the presidential elections in 1992. Consequently, President Dos Santos was entitled to run for another two consecutive or three non-consecutive terms.

Initial plans to hold presidential elections in 2009 could not be carried out as the governing elite decided to postpone them subsequent to the approval of a new constitution. However, in the last stages of the constitutional reform process, President Dos Santos pushed for the indirect election of the president of the Republic. His proposal differed from the MPLA's constitutional project, 
which granted strong executive powers to the president, who had to be directly voted into office by the electorate while having the extensive executive powers restrained by a system of checks and balances. In reality, what was at stake was President Dos Santos' reduced capacity to attract votes in comparison to the strong national following of the MPLA. ${ }^{5}$

This has strengthened the argument that President Dos Santos was concerned about getting fewer votes than the MPLA, as that would have weakened his authority within both the ruling party and the state. As a result, President Dos Santos influenced the ruling party to make a volte-face on their constitutional proposal (submitted to the National Assembly) in support of his favoured constitutional proposal (Model C), which incorporated the indirect method of electing the head of state to be adopted in the new constitution.

In the end, this institutional arrangement constituted a win-win situation for both President Dos Santos and the ruling party in their strategy to retain power in Angola in the long run. In the short term, the fusion of presidential and legislative elections addressed the issue of President Dos Santos' lack of charisma and popularity with the voters. He would be elected on the MPLA's ticket as he was the president of the party and was entitled to occupy the top position on the party's list. In the long run, particularly in the event of President Dos Santos being unavailable to run for office, the system ensured that an MPLA-fielded candidate would win the presidency, which happened in the 2017 general elections when João Lourenço ascended to the presidential office.

\section{The Politics of Institutionalising Local Elections}

Although a new constitution has been enacted and three general elections held since the end of the civil war, no local government elections have yet been held. Looking at the zero sum nature of electoral politics in Angola, where the winner of the general elections (at national level) takes all (appointing all government officials from national down to the local level), this section of the study argues that the Angolan government's failure to implement the autarquias locais (elected local government bodies) seems to be part of the ruling party's strategy to preserve its hegemony over the Angolan political system through electoral containment.

At the heart of political and administrative decentralisation is the transfer of power from the central government to local units of power. This makes the call for decentralisation not only a reflection of the view that a decentralised government

5 President Dos Santos has never been elected into office by popular vote despite being in office for almost three decades at the time of the constitutional reform process. In his first attempt to get elected, he proved to be less popular than his party, scoring 49.5\% against the MPLA's $53.7 \%$ in the 1992 elections. 
brings government closer to the people, thus fostering accountability, but also the notion that local government improves democracy in its participatory form.

The literature on democratisation acknowledges its ambiguous nature by stressing the means by which local government fosters democratic vitality and the challenges associated with such endeavours. For instance, Larry Diamond (1999, p.122) points out that local government contributes to the development of democratic values and skills amongst citizens; increases accountability and responsiveness to local interests and concerns; improves the representative chances of marginalised groups; enhances checks and balances vis-à-vis the centre; and provides opportunities for opposition parties at the national level to exercise a modicum of power at the local level. In contrast, scholars have cautioned against viewing decentralisation as the panacea for developing democracy and good governance (Cheema 2005, p.121). In certain circumstances, decentralised governance may create authoritarian fiefdoms, aggravate regional inequalities, and even stimulate geographical or ethnic secessionist demands (Troco 2018).

Notwithstanding these virtues and pitfalls, Angola is one of the many African countries that have subscribed to the principles of political and administrative decentralisation. Constitutional documents enacted since the end of formal oneparty rule (even before, if one looks closely at the 1975 LCRA) have referred to the institutionalisation of autonomous local representative structures. The first democratic constitutional document makes references to the autarquias locais (or local government bodies) with elected representative structures and freedom to administer their communities (art.146, LCRA 1992). The new constitution reinforces these provisions by describing the autarquias locais as elected local government bodies comprising an assembly with decision-making powers, a collegiate executive body and a president (art. 217-222, CRA 2010).

Despite these constitutional provisions the truth of the matter is that no autarquias locais have yet been set up. As a result, the country has no locally elected officials; all state officials at the local level (province, municipality and districts) are appointed by the central government. This state of affairs begs the question about why government has failed to implement the constitutionally-sanctioned mandate to establish elected local governing bodies.

Although the government emphasises the security situation of the 1990s and the preparation of the 'right conditions' after the end of the war as the main factors preventing the institutionalisation of elected local government bodies, the ruling party does not have political incentives to decentralise power. Realistically, the current structure of sub-national government does not require the MPLA to share power with any political party at the local level, but this situation could change if the ruling party were to institutionalise locally elected government. 
Currently, the structure of local government in Angola comprises three strands: provincial, municipal and district levels. ${ }^{6}$ These different spheres enjoy little policy, budgetary or fiscal autonomy because of a rigid top-down relationship with the central government based in Luanda. In addition, the central government controls the appointment of all senior officials at sub-national level. Accordingly, the president of the Republic appoints the 18 provincial governors who are politically and institutionally accountable to him alone (art 201/3, CRA). Provincial governors (in consultation with the Ministry of Territorial Administration) appoint the 164 municipal administrators, who in turn appoint the 528 district administrators.

This situation has some serious political and administrative implications. Firstly, it has turned Angola into one of the most politically and administratively centralised states on the African continent. ${ }^{7}$ Secondly, it strengthens the zero-sum nature of national politics, where the party that wins the general elections gets to fill all state administrative offices with its cadres. Thirdly, it has turned local government into a highly politicised and party-oriented sphere of governance, dominated by the ruling party.

As mentioned above, the MPLA not only appoints all senior state officials at the local level; but these appointees quite often double their positions in government with the chairmanship of the party at the level of their state jurisdiction. For instance, provincial governors are often the leaders of the MPLA in their respective provinces. The same logic applies to municipal and district administrators. This configuration of sub-national government also shifts the role of local government from delivering services and welfare to the citizenry to a structure that advances the interests and concerns of the governing party. This problematic feature of sub-national government in Angola tends to heighten during electoral periods, as the ruling party deploys massive state resources at the service of the party, thus blurring the lines between party, government and state alluded to in the previous section.

Institutional democratic reforms have now reached the point of no return and the MPLA cannot formally renege on the commitment to implement elected local government structures; however, the party has approached the matter with extreme caution. The MPLA's actions and policies, informed by the principle of gradualism, are indicative of the party's strategies to implement the decentralisation process without losing actual political power. Article 242 of

6 The municipalities are administrative regions within provinces while districts are administrative regions within the municipalities.

7 Angola is the only country in southern Africa that has not institutionalised elected local government. Once the country manages to set up locally elected government bodies these will be restricted to the municipal level. The appointment of provincial premiers will continue to be a prerogative of central government. 
the constitution states that 'the effective institutionalisation of local authorities shall obey the principle of gradualism'. In the Angolan context, gradualism means, theoretically, that large reforms should not be implemented at once, but progressively, bit by bit. However, in practice, reforms are being implemented at a very slow pace under the strict control of the ruling party, which may explain why the government has continuously delayed local elections. In the immediate post-war period, local elections had been planned for 2011 (EUEOM 2008, p.42) and later for 2015. More recently, the Minister of Territorial Administration has announced that the institutionalisation of elected local government will start in selected municipalities in 2020 and spread to all municipalities by 2035 (O Pais, $22 / 05 / 2018$ ). In response to the government's proposal, opposition parties have been calling for the simultaneous implementation of elected local government in all municipalities. The crux of the problem seems to lie with the interpretation of the principle of gradualism. The ruling party understands it in territorial or geographical terms (gradualismo geográfico), while opposition parties interpret it in terms of progressive transference of responsibilities from the central government to the municipalities (gradualismo funcional). However, the careful management of the institutionalisation of autonomous local representative structures suggests a concerted effort by the ruling party to control the pace and direction of change in order to pre-empt possible threats to its hold on power.

\section{PROSPECTS}

The extant political order in Angola is still authoritarian, according to several indexes of democracy. For instance, the Freedom House Index, an annual freedom barometer that measures the levels of civil and political freedom in the world, has consistently placed Angola in the 'Not Free' category, a proxy for authoritarian states (Freedom House 2018). Similarly, the Economist Intelligence Unit's Index of democracy has consistently classified Angola as an authoritarian state (EIUI 2018). However, judging by how the ruling elite conditions the effective functioning of constitutional provisions for a multiparty democratic dispensation, particularly free and fair electoral competition, Angola is best defined as an electoral authoritarian state of a hegemonic type.

Both quantitative and qualitative empirical studies have established that elections tend to have a liberalising effect in competitive electoral authoritarian regimes (Howard \& Roessler 2009; Brownlee 2009). This is because competitive regimes have meaningful 'arenas of contestations', such as the electoral, legislative, judiciary and the media through which opposition forces may periodically challenge, weaken, and occasionally, even defeat autocratic incumbents (Levitsky \& Way 2010, p.7). The same cannot be said of hegemonic electoral authoritarian 
regimes. These regimes tend to be stable as the incumbent controls all the relevant sites of state power, including the electoral arena, its actors and outcomes. They remain stable as long as elections remain non-competitive. In the words of a prominent academic in the field: 'elections are a mode of transition in competitive, but not hegemonic authoritarian regimes' (Brownlee 2009, p.144).

From this perspective, prospects for democratisation in post-war Angola are not promising. Although the MPLA has lost parliamentary seats in every election since 2008, this has not translated in an effective loss of power and since the country's accession to independent statehood, the ruling party has entrenched its domination over the Angolan state and society. The party still controls the presidency; it has more than the required number of seats in parliament to change or approve any piece of legislation it wishes; and also has a monopoly over government policy-formulation, implementation and decision-making in general. In these circumstances and in the absence of a political (or even a social) revolution, meaningful democratic reforms in the country will take place only if the MPLA undertakes a reform of its modus operandi.

In addition, the ruling party espouses certain practices and principles that are not conducive to democracy. For instance, the MPLA's actions and policies are informed by the principle of gradualism, meaning that large reforms are implemented at very slow and controlled pace so as not to weaken the party's hold on power, illustrated by the politics of implementing elected local government discussed above. In addition, the party has a long tradition of single-candidate contests for the presidency with candidates winning with astonishing majorities. In 2016, President dos Santos was re-elected head of the party with 96.6 percent of the votes. ${ }^{8}$ Two years later, his successor, President João Lourenço was elected with 98.59 percent of the votes (Jornal de Angola, 9 September 2018). This is perceived as a deficit of democratic traditions in the ruling party, as no political leader in contemporary liberal parties runs unopposed and wins with such majorities.

The MPLA still practices democratic centralism, an organisational principle borrowed from the Communist Party of the Soviet Union. It combines the discussion of policies and election of executive officials at all levels with the acceptance and implementation of decisions made by hierarchically superior decision-making bodies. This results in a strong top-down approach, excessive centralisation of power and suppression of internal dissent. In recent times, this was observed in the selection of the party's presidential candidate, a decision made by the higher echelons of the party (President Dos Santos and the Political Bureau) without the participation of rank and file party members. It also became

8 More at: https://www.dw.com/pt-002/josé-eduardo-dos-santos-reeleito-presidente-dompla/a-19492171 [viewed 6 September 2018]. 
evident during the debates on the perils of bicefalia (the existence of two centres of power, namely the party and the state) that arose when President João Lourenço took up the position of head of state, while President Dos Santos remained head of the ruling party.

There are, however, signs of hope now that President João Lourenço has taken over the helm of both the state and the ruling party and has initiated a series of reforms in these two spheres of the Angolan polity. There is a strong sense of optimism and renewed hope for a more open society and a more accountable government. All these developments are taking place against the backdrop of an emerging narrative that speaks of the re-birth of the Angolan state.

\section{CONCLUSION}

This study explores the relationship between electoral politics and political transition with particular reference to the Angolan experience in the aftermath of its civil war. Building on the theoretical assumptions that elections can be used both as instruments of democracy (Powell 2000) and as tools of authoritarian rule (Schedler 2015), the article focused on the progress, problems and prospects for democratisation that the resumption of electoral politics has had on the political trajectory of the country since the end of the armed conflict in 2002.

The analysis of evidence gathered from secondary data sources supports the view that post-war Angola has registered political changes pointing to a return to democratic normalcy. These include the organisation of three consecutive electoral cycles, a presidential succession, the promulgation of a brand-new constitution, and the announcement of the date for the country's local elections. However, a critical examination of these events shows how these developments have been used to ensure continued MPLA dominance over the Angolan political system. In other words, the ruling party uses its control over the state and state structures to manufacture electoral hegemony. This in turn is subsequently used to engender other types of political domination, such as approving a self-serving constitution (constitutional hegemony) and delay the implementation of elected local government bodies (central government hegemony).

Despite these challenges, Angolans are currently living in a climate of renewed hope brought about by the election of a new president. Since taking over from President Dos Santos, President João Lourenço has initiated a series of reforms, including a strong anti-corruption rhetoric. This has led to a narrative that speaks of the consolidation of Angola's democratic process, a process that is still unfolding at the time of writing. 


\section{Acknowledgement}

The financial assistance of the National Institute for the Humanities and Social Sciences-Council for the Development of Social Science Research in Africa (NIHSS-CODESRIA), the Social Science Research Council (SSRC) and the NRF/ British Academy Research Chair in Political Theory towards this research is hereby acknowledged. Opinions expressed and conclusions arrived at are those of the author and are not necessarily to be attributed to the NIHSS-CODESRIA, SSRC and the NRF/British Academy Research Chair.

\section{REFERENCES}

Alexandrino, JM 2013, O Novo Constitucionalismo Angolano, Instituto de Ciências Jurídico-Políticas da Faculdade de Direito da Universidade de Lisboa. Available at $<$ www.icjp.pt $>$ [10 April 2014].

Ake, C 2000, The Feasibility of Democracy in Africa, Codesria, Dakar.

Angola 2010, Constitution of the Republic of Angola, [Constituent Assembly, Luanda]. Angola 1992, Constitutional Law of the Republic of Angola, [National Assembly, Luanda].

Bogaards, M 2004, 'Counting parties and identifying dominant party systems in Africa', European Journal of Political Research, vol. 43, pp. 173-197.

Bratton, M\& van deWalle, N1997, Democratic Experiments in Africa: Regime Transitions in Comparative Perspective, Cambridge University Press, Cambridge.

Brownlee, J 2009, ‘Harbinger of Democracy: Competitive Elections before the End of Authoritarianism', in Lindberg, S (ed), Democratization by Elections, Johns Hopkins University Press, Baltimore.

Carothers, T 2002, 'The End of the Transition Paradigm', Journal of Democracy, vol.13, no.1. pp. 5-21.

Cheema, S 2005, Building democratic institutions, Kumarian Press, Bloomfield.

COE 2012, Relatório Final de Observação das Eleições Gerais de 2012, Available at: $<$ https://www.ndi.org/sites/default/files/COE\%20Final\%20Elections\%20 Report_COE\%202012_PORT.pdf> [12 January 2017].

D'Anieri, P 2013, 'Electoral tactics and autocratization', Comparative Democratization, vol.11, no. 2. pp. 1-6.

Diamond, L 1999, Developing Democracy: Toward Consolidation, Johns Hopkins University Press, Baltimore.

Economist Intelligence Unit 2018, World Democracy Report, <https://www.eiu.com/ topic/democracy-index.>.

Elklit, J \& Svensson, P 1997, 'What makes elections free and fair', Journal of Democracy, vol.8, no.3, pp. 51-65.

EUEOM (2008). Angola Final Report: Parliamentary Elections 5 September 2008. 
Available at: http://www.eods.eu/library/fr_eueom_angola_08_en.pdf. [5 February 2016].

Faria, CJ 2013, The Post-war Angola: Public Sphere, Political regime and Democracy, Cambridge Scholars Publishing, Newcastle.

Freedom House 2018, Angola, https://freedomhouse.org/report/freedom-world2018-table-country-scores.

Howard, M \& Roessler, G 2009. 'Post-cold War Political Regimes: When do Elections Matter?', In Lindberg, S. (ed). Democratization by Elections: A New Mode of Transition, Johns Hopkins University Press, Baltimore, pp.101-125.

HRW 2009, Democracy or Monopoly?: Angola's Reluctant Return to Elections, Human Rights Watch, New York.

Huntington, S 1991, The Third Wave: Democratization in the Late Twentieth Century, University of Oklahoma Press, Oklahoma.

Hyden, G 2006, African Politics in Comparative Perspective, Cambridge University Press, Cambridge.

Jackson, R \& Rosberg, CG 1982, Personal Rule in Black Africa: Prince, Autocrat, Prophet, Tyrant, University of California Press, Berkeley.

Katz, R 1997, Democracy and elections, Oxford University Press, Oxford.

Levitsky, S \& Way, L 2010, Competitive Authoritarianism: Hybrid Regimes after the Cold War, Cambridge University Press, Cambridge.

Matsimbe, Z \& Domingos, N 2018, 'Angola's 2017 Elections and the Start of the Post-Dos Santos Era', Journal of African Elections, vol.17, no 1, pp. 1-24.

Mbaku, JM \& Ihonvbere, JO (eds) 1998, Multiparty Democracy and Political Change: Constraints to Democratization in Africa, Ashgate, Suffolk.

Medvic, SK 2013, Campaigns and Elections: Players and Processes, Routledge, New York.

Morse, Y 2012, 'The Era of Electoral Authoritarianism', World Politics, vol. 64, no. 1, pp. 161-198.

Okoth-Ogendo, HWO 1991, ‘Constitutions Without Constitutionalism: Reflections on an African Political Paradox', in Shivji, I (ed), State and Constitutionalism: An African Debate on Democracy, Sapes, Harare.

O Pais. No. 1120. Tuesday 22/05/2018 [Angolan Newspaper].

Pearce, J et al. 2018, 'Briefing: Angola's Elections and the Politics of Presidential Succession', African Affairs, vol. 117, no. 466, pp. 146-160.

Pereira, G 2013, 'O Desenho Constitucional e a Presidencializacao do Sistema de Governo', Observatorio Politico, Working Paper \#22. Available at: <http:// www.observatoriopolitico.pt/wp-content/uploads/2013/02/WP_22_ GP.pdf> [10 March 2018].C

Pestana, N 2011, Sistema "parlamentar-presidencial" ou presidencialismo extremo?, Chr. Michelsen Institute, Bergen. 
Powell, GB 2000, Elections as Instruments of Democracy, Yale University Press, New Haven.

Roque, PC 2009, 'Angola's façade democracy', Journal of Democracy, vol. 20. no.4. pp. 137-150.

Sachiambo, A 2010, Constituição: a razão do povo e a tirania da maioria. 21 january 2010. Available at: <https://www.publico.pt/2010/01/21/jornal/constituicao-arazao-do-povo-e-a-tirania-da-maioria-18630641> [15 April 2018].

Schedler, A 2015, The Politics of Uncertainty: Sustaining and Subverting Electoral Authoritarianism, Oxford University Press, Oxford.

Schedler, A 2002, 'The Menus of Manipulation', Journal of Democracy, vol.13, no.2, pp.36-50.

Scott, J 2007, 'Elections' in Sabato, LJ and Ernst, HR (eds), Encyclopedia of American Political Parties and Elections, Facts on File, Princeton.

Soares de Oliveira, R 2015, Magnificent and Beggar Land: Angola Since the Civil War, Oxford University Press, Oxford.

Troco, AA 2018, 'Determinants of Successful Secessions in Post-colonial Africa: The Case of South Sudan', Brazilian Journal of African Studies, vol.3. no. 6, pp.55-74.

Van de Walle, N 2002, 'Africa's Range of Regimes', Journal of Democracy, vol. 13, no. 2, pp. 60-80. 


\section{BIOMETRIC ELECTION TECHNOLOGY, VOTER EXPERIENCE AND TURNOUT IN GHANA}

\section{Samuel Adams and William Asante}

Samuel Adams is Professor and Dean in the School of Public Service and Governance, Ghana Institute of Management and Public Administration, Accra

William Asante is a PhD Candidate in the School of Research and Graduate Studies, Ghana Institute of Management and Public Administration, Accra

\section{ABSTRACT}

This study investigates the experiences of voters with election technologies such as the biometric system for voter registration and verification (BVRV), as well as whether such technologies affected both turnout and trust in Ghana's 2012 and 2016 elections. The paper also explores whether the introduction of BVRVs increased or decreased levels of voter trust in the Electoral Commission (EC) and election outcomes. Using both primary and secondary data, the study found that the introduction of BVRV in election management in Ghana influenced the turnout for both the educated and the uneducated. While most of the former were eager to experience this novel approach, the same could not be said of the latter, less educated group. The study noted that state institutions do not take population diversity into consideration when introducing technological interventions. They take it for granted that citizens have the same capability, resulting in the marginalisation and neglect of a large section of the populace; this lack of trust in turn has a negative effect on voter turnout. The study recommends that such inequities in society should be taken into consideration when implementing interventions like BVRV in election management, specifically in Ghana but also in other African countries with similar socioeconomic and political conditions.

Keywords: election technologies, voter turnout, Ghana, voter experience

\section{INTRODUCTION}

Elections are an indispensable and foundational feature of modern democracy. They empower the people to select their chosen candidates to steer the affairs of 
a state or country. Democratic elections require a state that is able, on the basis of pre-existing records or through an ad hoc procedure, to compile a reliable voters' list; and also implies that voters are able to identify themselves to the polling station staff, usually by showing voter cards or national identity documents (IDs). This important process often eludes developing countries as they demonstrate persistent difficulties in registering voters and establishing their identities. These difficulties emanate from the fact that no trustworthy system of national identification exists (Akpan \& Adagba 2018). For these reasons there is a rising trend towards modernising voter registration systems as part of electoral reform in most developing countries (Rosenberg \& Chen 2009).

In Ghana, election reform is not a recent phenomenon but has been part of the electoral process since the commencement of the Fourth Republic in 1992. Ghana's election management body (EMB) known as the Electoral Commission (EC) has initiated steps to build confidence in the electorate after the faulty 1992 elections that resulted in the boycott of the parliamentary elections by the opposition parties (Boafo-Arthur 1995; Ayee 1997). The 1992 election is generally acknowledged as faulty because voter identification was haphazard and left to the discretion of election officials (Asante 2008), which made it difficult to detect impersonation and double voting. However, prior to the 1966 elections the EC began to streamline the voter registration process by introducing photo ID cards for voters in the ten regional capitals and ten selected rural constituencies. The rest of the population were then issued thumb-printed ID cards due to funding constraints (Asante 2008). Prior to the 2000 and 2004 elections photo ID cards had been issued; but the unique feature in 2004 was that aside from the provision of a photo ID card, voters had their photographs embossed against their biographical details on the main register. This helped to reduce impersonation and double voting, and was continued in subsequent elections, though not without controversy, until 2012 when the biometric system for voter registration and verification (BVRV) was introduced. Measures were however introduced to make the biometric reform operational, leading to the replacement of the existing Public Elections Regulations otherwise referred to as Constitutional Instrument (C. I.)15 which had governed public elections since 1996. The new law C.I.75 gave legal effect to the introduction of the biometric system, resulting in the popular mantra by the EC 'No Verification No Voting' (NVNV). Despite the promising nature of the BVRV in Ghana's elections, one key challenge has been the EC officers' lack of consistency in applying the NVNV law. This led the major opposition party, the New Patriotic Party (NPP) to contest the outcome of the 2012 elections in court.

Since December 2018 Ghana's ten geographical regions have been augmented to sixteen; each region is also divided into metropolitan, municipal and 
district assemblies (MMDAs) in order to bring the government closer to the people and to facilitate service delivery by the central and local governments (Bening 2012). Constituencies are geographical divisions solely for the election of the representatives to the national legislature (see Article 47 of Ghana's 1992 Constitution). The distinction between urban and rural area is based predominantly on population size; an urban area has a population of 5000 or more whereas a rural area has a population of less than 5000 (Ghana Statistical Service 2014).

Electoral reforms may be an improved response to the desires and expectations of the electorates and occur when change is intended to foster and enhance impartiality, inclusiveness, transparency, integrity or accuracy of the electoral process (International IDEA 2006). These reforms have been outlined by authors such as Frempong 2008; Gyekye-Jandoh 2013; Debrah 2015; and Botchway and Kwarteng 2018. However, they have largely focussed on a cursory list of various reform initiatives in Ghanaian elections which supported the notion that reforms are a result of elite initiation, bargaining and consensus.

The introduction of biometric technology (BT) for identification and verification in Ghana's elections has also received attention in the extant literature (Golden, Kramon \& Fosu 2014; Boateng \& Akaba 2015; Dorpenyo 2016; Effah \& Debrah 2018); but these studies do not directly discuss the experiences of voters with BT in the 2012 and 2016 elections. For instance, Effah and Debrah (2018) examined the failure of Ghana's first attempt to use BT for voter identification and verification in its 2012 general elections. Employing activity theory as an analytical lens and interpretive case study for the methodology, these authors found that the effectiveness of biometric technology to provide reliable identification does not depend solely on its technical qualities but also on real-time connectivity between registration centres and an electronic national register.

Dorpenyo's (2016) study on the introduction of BT in Ghana's 2012 elections focussed on the role of technical communicators in technology adoption, centering his argument on the technical documents that accompany the biometric device. Also, Boateng and Akaba (2015) use Ghana's 2012 election to explore the difficulties and benefits of introducing BT in elections. Their study identified the slowing down of the voting process, inadequate understanding of the biometric system and breakdown of biometric verification devices as some of the difficulties. The benefits included substantial prevention of double voting and voting without relevant IDs. EC staff could use their discretion and allow voters to vote when they did not have the required ID, providing there were two or more witnesses to support their claim. This system was however open to abuse as EC officials were often intimidated by politicians who exploited this option. BT was designed to curb this malpractice. 
Golden et al. (2014) investigate patterns of biometric identification machine breakdowns in Ghana's 2012 elections and found that machine malfunction facilitated election fraud, including overvoting and ballot stuffing, especially where election observers were not present.

This paper departs from the previous studies mentioned above by investigating the experiences of voters with BT during the 2012 and 2016 elections. Specifically, the study's purpose is firstly, to identify whether the introduction of the BVRV prevented or encouraged the electorates to vote in 2012 and 2016; and secondly, to assess whether the introduction of the BVRV in Ghana's elections has increased or decreased the level of electorate trust in the EC and election outcomes. Using a qualitative case study approach, the outcome of this study is expected to highlight the social justice implications for election management in a developing country. The study argues in favour of a more humanitarian and participatory approach in implementing BVRV technology, highlighting the plight of the disadvantaged in the implementation process and suggesting remedies for similar programs in future.

The study reviews relevant literature on election technologies and election management, election technologies, and voter turnout, followed by a description of the research methodology, and study's findings. Finally, the conclusion offers pointers for policy practitioners and technical communicators in the future.

\section{ELECTION TECHNOLOGIES AND ELECTION MANAGEMENT}

Many countries such as Australia, Brazil, Canada, Philippines, and the United States of America (US) use various forms of computer technology in national elections (Card \& Moretti 2007; Boateng \& Akaba 2015). This is referred to as computerised democracy, one in which part of the electoral process is based on information technology (Boateng \& Akaba 2015). For the most part this application of technology is part of an attempt to redress electoral anomalies such as voting fraud, rigging, and impersonation. For instance, the difficulty of counting the ballots in Florida during the 2000 presidential election in the US drew the nation's attention to voting technology. Backed by funding from a new federal law, the Help America Vote Act of 2002, many US states have responded by installing touch-screen voting machines (Card \& Moretti 2007) aimed at ensuring greater transparency, trust and openness in governance and democracy.

In the same vein biometric identification systems are widely used for voter registration in developing countries. The International Institute for Democracy and Electoral Assistance (IDEA) observed that in 2014, 38 low and middle-income countries used biometrics to register voters and the number continues to rise (IDEA 2014). Specifically, different kinds of biometric infrastructure have been used in Zambia, Nigeria, Uganda, Mongolia, Fiji, Bangladesh, Ghana, Mali, Kenya, 
Cameroon, Sierra Leone, Mozambique, Zambia, Malawi, Rwanda, Senegal and Mauritania (IDEA 2017; Nwangwu 2015).

In a study focused on sub-Saharan Africa, Gelb and Diofasi (2016, p. 2) observed that biometric elections have been generously supported by donors. Their study focussed on the costs and benefits of applying BT in elections, particularly the potential of the technology to reduce the probability of seriously disputed elections that escalate into violence. The authors identified that BT may reduce the likelihood of serious post-election violence and as such is a worthwhile investment. Nonetheless, they identified two weaknesses of BT: first, using sophisticated technology does not necessarily increase the credibility or the fairness of elections and can even undermine it. The second concern is that costly one-off electoral registrations may divert attention and funding away from supporting civil registration and financially sustainable national identification systems that should provide the basis for voters' rolls.

Olurode (2017) acknowledges that elections in Nigeria are a matter of life and death because of their zero-sum game. The stakes are so high that electoral malpractices are common; when election technology, specifically electronic card readers were introduced in 2015, they prevented electoral manipulations and fraud. Olurode further opines that this technology paved the way for more credible and competitive elections in Nigeria. Akpan and Adagba (2018) share similar views and add that technology such as Information Communication Technology (ICT) can assist in the management of the electoral process so as to curb electoral malpractice.

In Ghana, Golden et al. (2014) investigate patterns of biometric identification machine breakdowns in the 2012 national elections. The authors observe that in a polling station with a randomly assigned election observer, machines were about $50 \%$ less likely to experience breakdown than in polling stations without observers. They again found that machine malfunction in turn facilitated election fraud including overvoting and ballot stuffing, especially where election observers were not present. These results corroborate the argument that partisan competition may promote election fraud in fledgling democracies. They further demonstrate that technological solutions are valuable but insufficient in solving political problems when political interests have the incentive and ability to manipulate the technology.

Effah and Debrah (2018) analyse why BVRV failed in Ghana's 2012 elections. They found that for BVRV to be effective in delivering credible elections accepted by all stakeholders, it should not depend solely on the technology but on how rapidly registration centres are able to connect with the electronic national register. More importantly, Boateng and Akaba (2015), Effah and Debrah (2018) and Dorpenyo (2016) concur that the application of BT in Ghana's 2012 elections 
was a failure; however, their opinions vary on how they identify this failure. Whereas Boateng and Akaba conducted a postmortem to identify BVRV's benefits and drawbacks, Dorpenyo looked at the implementation of BT and the role of technical communicators. This study contributes to existing knowledge by considering the implementation of BVRV in the 2012 and 2016 elections from the voter perspective and agrees with the above authors that Ghana's 2012 elections were faulty. However, it goes a step further to suggest that the 2016 elections were a major improvement, hence its outcome was accepted by all stakeholders.

The above discussions reveal that no single BT is expected to effectively meet the requirement of precision, cost, privacy concerns, legal complexities and pragmatism (Jackson 2009; Uludag et al. 2004). Magnet (2011) concurs, claiming that the biometric system is subject to major errors that include false acceptance rate (i.e. of an unauthorised user), false rejection rate (incorrect rejection) and the failure to enroll (machine error). The data gathered and the extant literature attest to the fact that though biometric technology has not always performed optimally it has been crucial in minimising double voting, impersonation, fraud and rigging, in election management.

A clear distinction exists between voter registration and verification regarding BT adoption in Ghana. Voter registration was phase 1 of the BVRV which began with identity checks, followed by the capture of biographical data, fingerprints and photograph of each voter. Verification followed on election day when voters were verified before being allowed to vote (Effah \& Debrah 2018).

\section{ELECTION TECHNOLOGIES AND VOTER TURNOUT}

Earlier studies to demonstrate factors or variables having causal effect on turnout include, but are not limited to the assumption that voters turn out when they realise that their vote might decide the elections, and also because of a feeling of civic responsibility (Riker \& Ordeshook 1968). In addition, rational wealthmaximising behaviour by the electorate may also lead to high voter turnout (Barzel \& Silberberg 1973; Filer \& Kenny 1980). A study by Knack (1994) tested the assumption that unpleasant weather conditions (rain) on election day reduces turnout; however, the result showed that rain does not significantly reduce the probability of voting. Farber (2009) sought to investigate whether making election day a national holiday increases voter turnout; the findings however revealed that an election holiday on its own does not necessarily increase voter turnout. Other studies on voter turnout consider the relationship between the closeness of elections and voter turnout (Matsusaka 1993; Shachar \& Nalebuff 1999), and the effect of legal changes such as that of the US Constitution on voter participation, specifically the $24^{\text {th }}$ Amendment (cancellation of the poll tax) and 
26th Amendment (lowering the voting age from 21 to 18 years) (Ashenfelter \& Kelley 1975; Filer, Kenny \& Morton 1991). However, the effect of election technologies on voter turnout (Roseman \& Stephenson 2005) is an area that has not received much attention in the literature. One of the objectives in this study is to add to the existing knowledge by investigating whether the introduction of BT in Ghana's 2012 and 2016 elections in anyway influenced turnout among the study's sampled voters.

The study by Roseman and Stephenson (2005) is one of the earlier attempts to investigate whether technology influences voter turnout. The authors revealed that after the Florida election fiasco of 2000, there was a strong emphasis on replacing voting equipment perceived as inferior (e.g. punch card ballots) with more technologically advanced methods. Some voters, especially the elderly, were apprehensive about computerised voting, which led to a low turnout of elderly voters. However, this situation is probably temporary as ongoing education and experience will help the elderly to adapt to the technology. Allers and Kooreman (2009) corroborate the work of Roseman and Stephenson in some respects, in that electronic voting had a small positive effect on voter turnout in Dutch elections initially but this cannot be guaranteed in the future.

Mugica (2015) observes that in automated elections, voters from all age groups consistently report that it is easier to vote electronically than with pen and paper. In addition, touchscreens facilitate voter turnout for the illiterate who can simply touch the picture of their candidate's face or the colour of their party with a finger. As a result, voters with disabilities are lobbying governments for computer-based systems which will allow them to vote without assistance.

\section{METHODOLOGY}

This study uses qualitative research design which emphasises textual analysis in social research (Bryman 2012). The purpose of qualitative research is to understand or explain behaviour and beliefs, identify processes and understand the context of people's experiences (Hennink, Hutter \& Bailey 2011).

According to Creswell (2007), different approaches for qualitative research include phenomenology, narrative, grounded theory, case study and ethnography. The case study is deemed appropriate for this study as it provides detailed, indepth collection of data involving different sources of information. Ghana is chosen as the case study to investigate voter experience with BT during their 2012 and 2016 elections. It is a lower middle-income country where urban areas have a higher literacy rate than rural areas and where elections are seen as a zero-sum game. This is also the case in Nigeria, and we are of the view that any country with similar conditions to those in Ghana could benefit from this study. 


\section{Data Collection and Analysis}

The study relied on semi-structured interviews as the primary means of field data collection. These interviews were conducted in two of the swing regions of Ghana, Greater Accra and Central. Swing regions in this context are those that are not committed to voting for a particular party or candidate. In each of these regions, one rural and one urban constituency were purposively selected. In the Greater Accra region (GAR), the Korle Klottey Constituency was selected to represent the urban constituency, and the Shai Osudoku Constituency to represent the rural constituency. In the Central Region (CR), the Cape Coast North Constituency was selected to represent the urban constituency and Senya West the rural constituency. In each of the urban and rural constituencies in the two regions, eight categories of interviewees were sampled and interviewed (see Table 1 below).

Table 1: Demographics of Respondents

\begin{tabular}{|c|c|c|c|c|c|}
\hline \multicolumn{3}{|c|}{ Rural } & \multicolumn{3}{c|}{ Urban } \\
\hline $\begin{array}{c}\text { Educated } \\
\text { Voters }\end{array}$ & $\begin{array}{c}\text { Uneducated } \\
\text { Voters }\end{array}$ & EC Officials & $\begin{array}{c}\text { Educated } \\
\text { Voters }\end{array}$ & $\begin{array}{c}\text { Uneducated } \\
\text { Voters }\end{array}$ & EC Officials \\
\hline 8 & 8 & 1 & 8 & 8 & 1 \\
\hline
\end{tabular}

Source: Author's compilation 2018

The use of 'educated' here refers to informants who have completed senior high school and above, whereas the term 'uneducated' is used for interviewees with no education or who have dropped out from basic (primary) education.

Two EC officials were also selected and interviewed, one from the Shai Osudoku District (Greater Accra Region) and the other from the Cape Coast Metropolitan District (Central Region). One EC official represented the Urban District (Cape Coast Metropolitan) whereas the other represented the rural (Shai Osudoku). In total 34 interviewees took part in the study. The selection of informants took into consideration their age, voting experience in the last two elections (2012 and 2016) and citizenship (whether informants were Ghanaians). All interviewees were assured that the information they gave was strictly confidential and for academic purposes only. Before the interviews, the study's objective was clearly explained to the interviewees after which they were asked to sign the consent form indicating their willingness to continue. Each interview lasted between 35 and 60 minutes and took place at venues of their choice, mostly their own homes and public places such as bars and restaurants. 
Secondary data was obtained from nationwide surveys by Afrobarometer and a team of researchers from the Ghana Institute of Management and Public Administration (GIMPA). The Afrobarometer Round 6 survey used in this study was conducted in Ghana by the Center for Democratic Development (CDD-Ghana). The survey is sourced from a nationally representative sample of adult citizens with all respondents randomly selected. Face-to-face interviews were conducted in the language of the respondent's choice. Standard questionnaires were used and allowed for comparisons across countries and over time. A sample size was chosen of 2400 with a margin of error of $\pm 2 \%$ at a $95 \%$ confidence level. Fieldwork for Round 6 in Ghana was conducted between May and June 2014.

The 2017 survey from GIMPA was also designed as a representative nationwide sample survey on voting behaviour with a sample size of 3200 voters on the 2016 general elections in Ghana at a confidence level of 95\% and a confidence interval of two. The survey respondents were drawn from 95 out of 275 constituencies in the administrative regions. In each region, at least onethird of the total constituencies were selected using simple random procedure. The sample of 95 constituencies represents $38.8 \%$ of the total 275 constituencies. In terms of the distribution of the survey questionnaires, a total of 3200 were allocated based on the region's proportionate share of the national results of the total votes cast in the 2016 general elections. Thus, the Ashanti region had the highest percentage (22\%) while Upper West had the lowest percentage (3\%). In all, 3160 questionnaires were returned representing a 98.8\% response rate.

Subsequently, the household was the primary sampling unit and respondents were those individuals who had voted during the 2016 election. The Household Selection Kish Grid was used to select households based on a specific interval of three and five for rural and urban areas respectively. The respondent Kish grid was further used to select one respondent from each household where there were more qualified respondents. To ensure gender balance, the research assistants were tasked to repeat the process until the 1580 respondents had an equal number of females and males. The study also randomly selected an equal number of 1580 respondents from rural and urban constituencies. Tables 2 to 5 show a section of the survey respondents' biodata.

Table 2: Age of Respondents

\begin{tabular}{|c|c|c|}
\hline Responses & Frequency & Percent \\
\hline NR & 9 & 0.28 \\
\hline $18-30$ & 929 & 29.40 \\
\hline $31-40$ & 1087 & 34.40 \\
\hline
\end{tabular}




\begin{tabular}{|c|r|r|}
\hline $41-50$ & 615 & 19.46 \\
\hline $51-60$ & 375 & 11.87 \\
\hline $60+$ & 145 & 4.59 \\
\hline Total & $\mathbf{3 1 6 0}$ & $\mathbf{1 0 0 . 0 0}$ \\
\hline
\end{tabular}

Source: Survey Data, 2017.

Table 3: Gender of Respondents

\begin{tabular}{|l|c|c|}
\hline Responses & Frequency & Percent \\
\hline Male & 1580 & 50.00 \\
\hline Female & 1580 & 50.00 \\
\hline Total & $\mathbf{3 1 6 0}$ & $\mathbf{1 0 0 . 0 0}$ \\
\hline
\end{tabular}

Source: Survey Data, 2017.

Table 4: Location of Constituency

\begin{tabular}{|l|c|c|}
\hline Responses & Frequency & Percent \\
\hline Urban & 1580 & 50.00 \\
\hline Rural & 1580 & 50.00 \\
\hline Total & $\mathbf{3 1 6 0}$ & $\mathbf{1 0 0 . 0 0}$ \\
\hline
\end{tabular}

Source: Survey Data, 2017.

Table 5: Level of Education

\begin{tabular}{|l|c|c|}
\hline Responses & Frequency & Percent \\
\hline NR & 24 & 0.76 \\
\hline No Formal Education & 336 & 10.63 \\
\hline Primary Education & 151 & 4.78 \\
\hline JSS & 540 & 17.09 \\
\hline SSS & 540 & 17.09 \\
\hline Teacher Training/Polytech & 231 & 7.31 \\
\hline Tertiary & 1338 & 42.34 \\
\hline Total & $\mathbf{3 1 6 0}$ & $\mathbf{1 0 0 . 0 0}$ \\
\hline
\end{tabular}

Source: Survey Data, 2017. 
Analysis of the primary data used the qualitative content analysis technique, which according to Hsieh and Shannon $(2005$, p. 1278) is a '... method for the subjective interpretation of the content of text data through the systematic classification process of coding and identifying themes or patterns'. After collecting the data, it was transcribed and then a narrative was derived from the transcription. Interview notes were coded in which similar codes were clustered into themes representing the objectives of the study. The data from the secondary sources [representative nationwide surveys] were analysed using the descriptive statistical method with the help of the SPSS version 23 software package to develop frequency distribution tables and line graphs.

\section{FINDINGS}

The following section analyses the findings based on pre-selected themes derived from the objectives: BVRV technology and voter experience and turnout; perceptions of trust in BVRV technology; and perceptions of trust in the EC.

\section{BVRV Technology and Voter Experience and Turnout}

The study's investigation into whether BVRV prevented or encouraged the electorate from voting in the 2012 and 2016 elections had various responses after interactions with key informants at research sites.

A female interviewee in the 25-35 age group, with tertiary education (teacher training school) in the Cape Coast North Constituency in the Central Region pointed out that:

I think the introduction of the BVRV encouraged me to vote in the 2012 elections because I was very anxious to know how it really works ... I think the BVRV did not encourage me to vote in the 2016 elections because after my experience with 2012, it wasn't the BVRV that encouraged me rather it is because it was my right to vote.

A male public servant from Senya West recounted that:

In 2012, it was quite an experience, the process was very easy and the time spent was minimal, even though there were challenges. For the 2016 elections, everything was ok.

Another male in the 35-45 age group with tertiary education from the Korle Klottey Constituency, described his experience: 
During the 2012 elections, I personally did not have any problems, I had read a lot about the BVRV on the internet and in the newspapers...

Most of the key interviewees, and in particular the better-educated and technologically savvy voters, shared similar views. This suggests that they were curious to have first-hand unique experience of this technology. This is consistent with the findings of Roseman and Stephenson (2005) that the introduction of new technology influences voter turnout. On the same trajectory the assertion of the interviewee above that she voted in 2016 because it was her right to do so, supports the findings of Riker and Ordeshook (1968) that voters are likely to vote because they feel some civic responsibility.

A male interviewee with tertiary (university) education in the 35 to 45 -year group, from the Korle Klottey Constituency, Greater Accra mentioned that;

I think the introduction of the BVRV encouraged me to vote in the 2012 elections. I thought 2012 election will be one of the most credible elections in the country because of the BVRV but people managed to manipulate the election results especially the presidential. I was not pleased with the outcome.

This supports the argument that no single biometric is expected to meet the requirement of completely eliminating fraud and manipulation (Jackson 2009; Uludag et al. 2004), cementing the argument that the occurrence of errors with BVRV is likely. Magnet (2011) notes that the biometric system is subject to three forms of errors i.e. false acceptance, false rejection and failure to enroll.

The same informant went further to express his experience with the BVRV technology in the 2016 elections:

I think the introduction of the BVRV encouraged me to vote in the 2016 elections. Before 2016 election, a lot of education about the BVRV was held for all stakeholders and they understood the dynamics of the BVRV. This gave me 100\% confidence that the 2016 election will be more credible than the previous one (2012).

In addition, a male in the Senya West constituency with educational background up to university level commented:

On a scale of first to fifth, I rank the introduction of the BVRV as the fourth push factor that made me vote in the 2012 elections, on the other hand, I rank the introduction of the BVRV technology as the third push 
factor that made me vote in the 2016 elections. This is because 2012 was a good attempt with the BVRV technology but 2016 was better, less complaints.

In contrast with the above experiences, another male informant in the 35 to 45-year group, educated up to senior high school and from the Shai Osudoku constituency commented:

I do not think the introduction of the BVRV encouraged me to vote in the 2012 elections. I did not vote because of the introduction of the BVRV, rather because it is my right to vote ... I do not think the introduction of the BVRV encouraged me to vote in the 2016 elections, it didn't in anyway encouraged me to vote.

This confirms the issue of civic responsibility as described by Riker and Ordeshook (1968).

A male aged between 45 and 55 years with no educational background, from the Korle Klottey Constituency in Greater Accra, asserted that:

I was very nervous when I first heard of the introduction of the BVRV technology in our elections in 2012. I complained bitterly because I did not know anything about it and how the experience will be like. Initially I thought it was a strategy to rig the elections. I didn't know it was to strengthen the election process. I was saved by my son who is more educated and knowledgeable about the process.

A similar experience was recounted by a key informant, a woman in the 55 to 65-year group with no educational background, in the Senya West Constituency. She expressed disappointment with how she felt left out, asserting that:

I was frightened when I heard on radio that now before you vote, you need to be checked by a computer before you can vote. I was discouraged totally to vote. I did not go out to vote in the 2012 elections but in 2016 my granddaughter encouraged me, and assisted me to the polling station.

An interviewee from Shai Osudoku with no educational background and between the ages of 55 and 65 , recounted that:

Immediately I heard this on radio, I said to myself, this politicians are at it again to make life miserable for some of us...my nephew had 
experienced this same computer when he finished the Junior High School, he was placed at a school in Tamale (northern part of Ghana) even though he did not choose that school; so seriously I wasn't enthused about the policy at all and so I didn't vote in 2012.

Another interviewee with no educational background from Cape Coast North Constituency, described her experience thus:

In the first election when the biometric machine was used (referring to the 2012 elections); I mustered courage to vote after I had been convinced by one of my neighbors that it was a simple technology, however, putting my finger on the machine to verify me was frightening.

These statements clearly indicate that while some of the informants benefitted from the introduction of BVRV technology, others, particularly the uneducated, felt disadvantaged and needed assistance. One notable point is that both the GAR and CR have a high proportion of people who had attended or were attending school in both urban and rural areas: GAR 90.9\% urban, $81 \%$ rural; CR $83.8 \%$ urban, $81 \%$ rural (Ghana Statistical Service 2013). This promising statistic suggests that any effort to educate the electorates on BVRV would have been widespread and easily understood. Aside from this, older Ghanaians have lower literacy rates than younger ones (Ghana Statistical Service 2013). This was also reflected in the sampled constituencies as most of the uneducated interviewees are in the older age bracket. Uneducated and/or aged informants were frequently at a disadvantage and unfortunately institutions like the EC and National Commission for Civic Education (NCCE) failed to make them feel part of the election process, in particular BVRV technology. Fear of the unknown discouraged informants from exercising their constitutionally mandated right to vote. This is consistent with the argument of Slack and Wise (2005) that 'who or what someone is' affects technology use because technologies are developed to meet user needs.

Thus, when individuals who are expected to benefit from technology are side-lined in terms of access to appropriate information on technology usage, then the purpose of acquiring that technology has not been met. Confirming this view Winner (1989) also noted that technologies are not merely aids to human activity but are powerful forces reshaping that activity and its meaning. In similar vein, the argument is that had the disadvantaged been better educated they would have found BVRV simple, which would have encouraged voter turnout. The observation by Mugica (2015) strengthens the above argument that technology, if appropriately used, could increase the turnout of voters with disabilities, the uneducated, poor and destitute, thus encouraging inclusivity in the democratic process. 


\section{Perceptions of Trust in the EC and Election Outcome}

The issue of whether the introduction of BVRV has affected voter trust in the EC and election outcomes needs to be assessed in terms of the general trend of trust in the EC from 2002 to 2014, based on Afrobarometer data (see Figures 1 and 2 below). Two trust trends have been identified. The first trend as illustrated by Figure 1 looks at the percentage of respondents that have expressed little or no trust for the EC since 2002. The line graph reveals that from $2002,41 \%$ of respondents did not trust or had little trust in the EC, but this fell in 2005 to $21 \%$, possibly because of innovations introduced in the 2004 elections such as embossing the photographs of voters against their biographical details in the main register. Since 2005, the percentage of respondents who had little or no trust in the EC has continued to rise steadily to 59\% in 2014 (see Figure 1 below). Figure 2 also shows that in 2005, respondents expressed a high level of trust for the EC (75\%), but since then there has been a downward trend to $37 \%$ in 2014 . This low percentage rate may be due to EC inefficiencies in conducting the 2012 elections, with major stakeholders disagreeing on the results thus allowing the courts to intervene.

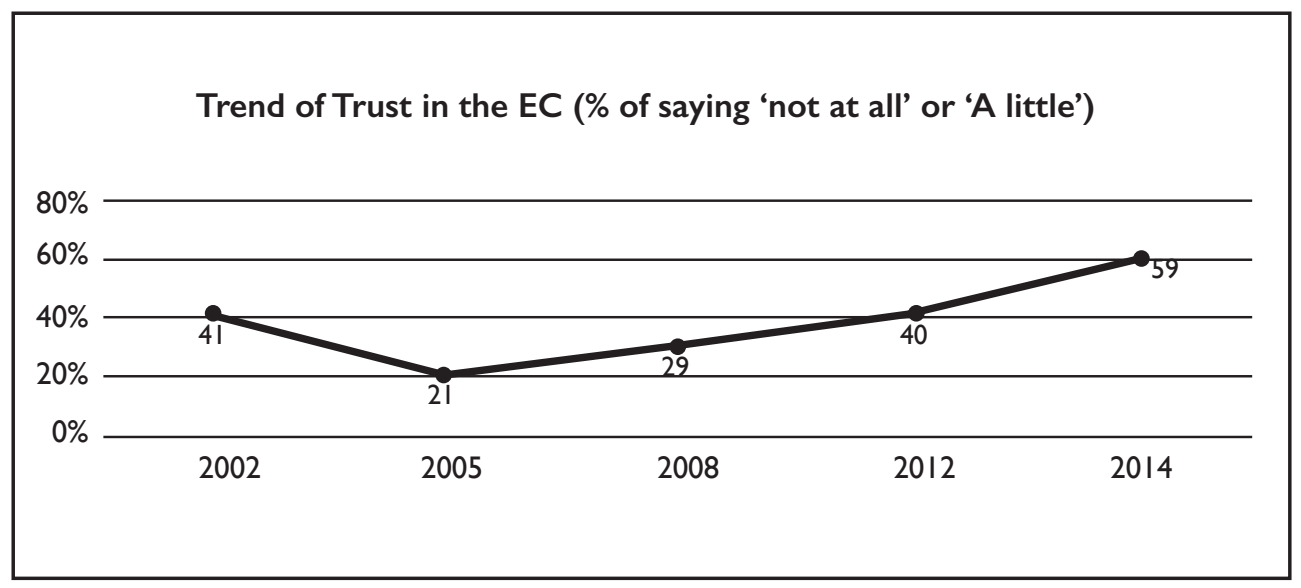

Source: Afrobarometer (2016)

Figure 1: Trend of Trust in the EC 


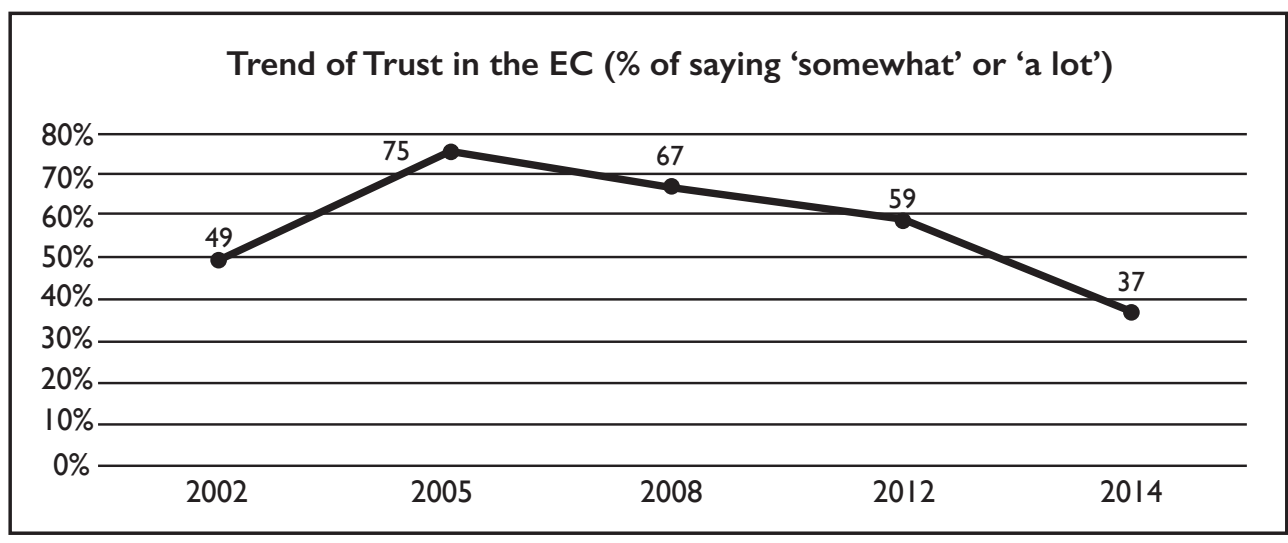

Source: Afrobarometer (2016)

Figure 2: Trend of Trust in the EC

The level of trust in the EC illustrated above shows that from 2005 onwards the percentage of respondents who had little or no trust in the EC kept increasing, while those who expressed somewhat or a lot of trust kept reducing. This may be as a result of the many questions that remained unanswered in the minds of the electorate. The key issue was the reliability of the voters' roll.

The GIMPA Survey also gauges the level of trust for the EC after the 2016 elections. Table 6 shows that $47 \%$ of respondents stated that they have huge trust in the EC, 30\% indicated that to some extent the EC could be trusted, $17 \%$ mentioned that they trusted the EC a little, while only $4 \%$ of the respondents indicated no trust at all for the EC. This is an improvement on the percentages in Figures 1 and 2, showing that those who did not trust the EC kept decreasing and those who trusted the EC kept increasing from 2005 onwards, suggesting that the EC gradually gained the confidence of the electorate after the 2016 elections. This is because major stakeholders agreed on the outcome of the elections, with both domestic and international election observers describing it as free and fair - unlike the contested election results in 2012 (Effah \& Debrah 2018; Boateng \& Akaba, 2015). Despite the adoption of the BVRV for the 2012 and 2016 elections, the electorate remains divided on the issue of trust. For example, one educated urban dweller in the Korle Klottey Constituency remarked:

I do not have confidence [trust] in the EC to conduct credible elections. This is because even with the introduction of the BVRV there have been incidents of electoral fraud. I see the EC as being politically influenced. 
This view was supported by a female interviewee (with no educational background) in the Shai Osudoku Constituency:

I do not have confidence [trust] in the EC to conduct credible elections because it is influenced by government and as such has no credibility. Imagine how the EC delayed in the final declaration of the results (referring to election 2016) even after all the media houses had collated about $95 \%$ of the results from the 275 Constituencies.

On the other hand, in the same Greater Accra Region a male interviewee educated to the tertiary level at the Korle Klottey Constituency mentioned that:

I have confidence in the EC to conduct credible elections; this is because political parties representatives and the media are given the opportunity to enter the ECs strong room to monitor the results of the elections...The introduction of the BVRV has increased my confidence in the EC; this is because the introduction of the BVRV has eradicated the practice of one person voting more than one.

Similarly, a secondary school leaver in the Shai Osudoku Constituency states that:

The introduction of the BVRV has not reduced my confidence in the EC. It has rather increased my confidence in the EC especially in the final results (referring to election 2016). It shows the true reflection of what happened at the various polling stations.

These responses depict the dynamics of what should happen in a typical swing region. That is to say, opinions should be diverse and based on unique experiences and access to information. Swing region Greater Accra demonstrates this in its voting pattern by alternating between the two major political parties in Ghana, the New Patriotic Party (NPP) and National Democratic Congress (NDC). The NDC has won four of the seven presidential elections in the Fourth Republic (1992, 1996, 2008 and 2012), with NPP winning the remaining three (2000, 2004 and 2016). The CR depicts a similar picture (Frempong 2015). From the foregoing, it appears that whenever a party wins these regions (GAR and CR), the presidential candidate of that party wins the overall national election. It must however be mentioned that although the GAR appears to be a swing region, some of the constituencies do not. A typical case is that of Shai Osudoku which consistently voted for the NDC from 1992 to 2016. To have interviewees in the Shai Constituency showing 
diverse opinions on the management of elections alongside experiences with the BVRV at a time when their favourite political party was in power (NDC), depicts the growing maturity of the Ghanaian voter. They are stating their opinions without being influenced by the broader context in which they find themselves. This further suggests that opinions on election management are not always linked to partisan politics or the context in which the respondent finds him- or herself.

Furthermore, some of the interviewees who criticised EC performance in its election management role, argued that it was dancing to the tune of the incumbent NDC regime. This may have been because the regime's communicators defended the efforts of the EC at every opportunity; but also because of over-reliance by the EC on government funding and the appointment of the EC chair by the president prior to the 2016 elections. Most citizens saw these as an incentive for the government to manipulate the $\mathrm{EC}$, hence leading to the allegation that the undue delay prior to the declaration of the 2016 results was intended to rig the elections in favour of the incumbent NDC government.

Table 6: Trust in the EC

\begin{tabular}{|l|c|c|}
\hline Responses & Frequency & Percent \\
\hline A lot & 1486 & 47.31 \\
\hline Somewhat & 936 & 29.80 \\
\hline A little & 532 & 16.94 \\
\hline Not at all & 128 & 4.08 \\
\hline Don't know & 59 & 1.88 \\
\hline Total & $\mathbf{3 1 4 1}$ & $\mathbf{1 0 0 . 0 0}$ \\
\hline
\end{tabular}

Source: Survey Data, 2017.

\section{Perceptions of Trust of BVRV Technology}

One of the major reasons for the introduction of BVRV was to inspire trust in the voters' roll. Respondents were thus assessed on their level of trust in the voters' roll after their experience with the BVRV in the 2012 and 2016 elections. The result was that $46 \%$ indicated that they trusted the voters register a lot, whereas $45 \%$ responded that they did not to have much trust in the voters' roll (Table 7). This clearly supports the findings that respondents' trust in the EC and voters' roll has not improved as much as expected. Respondents would have been expected to have a very high level of trust in the register and the EC after the adoption of the BVRV technology in 2016 (see Tables 6 and 7), but this was not so. 
Table 7: Trust in the Voters' Roll

\begin{tabular}{|l|c|c|}
\hline Responses & Frequency & Percent \\
\hline A lot & 1440 & 45.71 \\
\hline Somewhat & 879 & 27.90 \\
\hline A little & 531 & 16.89 \\
\hline Not at all & 168 & 5.33 \\
\hline Don't know & 132 & 4.19 \\
\hline Total & $\mathbf{3 1 5 0}$ & $\mathbf{1 0 0 . 0 0}$ \\
\hline
\end{tabular}

Source: Survey Data, 2017.

Another important issue was the assessment of respondents' perceptions of trust in the BVRV to detect electoral fraud. Table 8 indicates that $57 \%$ of the respondents replied that they have a lot of trust in BVRV technology to detect fraud, $26 \%$ stated that they trust the BVRV technology only somewhat, and only $14 \%$ of the respondents stated that they have just a little trust in the BVRV to detect fraud. That the level of trust of respondents in the BVRV technology is much higher (over $50 \%$ ) is possibly because of improved operations, as described by one educated male informant from the Korle Klottey Constituency in the Greater Accra Region:

I saw an improvement of the BVRV technology operations in the 2016 elections, the hullabaloo associated with the BVRV technology during the election 2012 which was subsequently sent to court was greatly improved in 2016. I must say the litigation process did a lot of good for election management in Ghana.

Another informant, an educated female in the Senya West Constituency, commented:

Well, the introduction of the BVRV system had some challenges at my polling station but I was confident about it that it will improve ... By 2016 during the election period, I realized the BVRV System had improved and reduced stress a little bit.

The experiences of these informants clearly indicate that their first experience with the BVRV technology was not good but incremental improvements were registered in their second experience. This suggests that the EC took into consideration the fallouts from the 2012 elections and most especially the reforms that the Supreme Court of Ghana recommended after the maiden presidential election petition 
(Asante \& Asare 2017). One of the EC officials from the Cape Coast Metropolitan District acknowledged that 'the post-2012 court case was a major contributory factor leading to the improvement in the 2016 elections. The reason being that the EC wanted to prevent another disputed election[s]'. Thus, it appears that voter trust in the EC and election outcome is gradually improving.

Table 8: Trust in the Biometric Verification System to Minimise Fraud

\begin{tabular}{|l|c|c|}
\hline Responses & Frequency & Percent \\
\hline A lot & 1788 & 56.96 \\
\hline Somewhat & 807 & 25.71 \\
\hline A little & 446 & 14.21 \\
\hline Not at all & 61 & 1.94 \\
\hline Don't know & 37 & 1.18 \\
\hline Total & $\mathbf{3 1 3 9}$ & $\mathbf{1 0 0 . 0 0}$ \\
\hline
\end{tabular}

Source: Survey Data, 2017.

\section{CONCLUSION}

This study set out to investigate first, whether the introduction of the BVRV prevented or encouraged the electorate to vote in the 2012 and 2016 elections; and second, whether the introduction of the BVRV has increased or decreased the level of trust by the electorate in the EC and election outcomes. In addressing the first objective, key informants pointed out that the BVRV encouraged them to vote because they were curious to experience new technology for the first time. This point of view emanated from most of the urban, highly educated and technology proficient informants. On the other hand, the less educated, mostly aged rural dwellers and those not exposed to technology, were apprehensive about the introduction of BVRV. Such individuals had family members rather than state institutions assisting them in how to use BVRV technology. Overall, while some of the key informants were comfortable with the BVRV, others were at a disadvantage and needed assistance. The uneducated, aged and in particular the rural informants were not encouraged initially whereas the educated - even those in rural constituencies - were encouraged to vote. They were undeterred by the new technology but curious to experience it.

Regarding the second objective, the findings indicate that a moderately high number of respondents stated that after the 2016 experience they trust the EC in conducting elections. Figures 1 and 2 also reveal that from 2002 to 2014 an increased number of respondents indicated no trust in the EC, whereas those with 
a lot of trust in the EC decreased around the same period. This decrease in trust might be as a result of the disputes emanating from the 2012 elections and the seemingly favourable posture demonstrated by the EC towards the incumbent NDC government prior to both the 2012 and 2016 elections.

The experiences of voters with BVRV technology were mixed; some interviewees indicated that the BVRV increased their confidence in the EC while others stated that it reduced their confidence in the EC concerning election management. Most of the informants pointed out that their first experience with BVRV technology was not so good; however, their second experience was an improvement. Based on the experiences of these informants, the elections of 2016 were an improvement over those of 2012. Thus, despite its challenges, the introduction of the BVRV is gradually building trust in the EC. One EC official acknowledged that the court case after 2012 was a major contributory factor leading to this improvement.

The above findings lead to some recommendations for policy makers, researchers and students of elections. With Ghana's top-down mode of BVRV implementation, it was unsurprising that the election outcome was contested in court after the 2012 elections. The elite were at the forefront of the implementation process, forcing technology on a helpless populace. There was inadequate time for public education, and professional technical communicators who could have created a more culturally inclusive outreach to aid public education and advocacy were ignored in the process.

Again, the pilot study for the test of the biometric device did not take into consideration population diversity and as a result some were excluded and the citizenry were not able to own the process. Most of the disadvantaged voters needed help from family members to keep up with the technology's implementation, or risk being marginalised and finding their right to vote curtailed.

Finally, and as acknowledged elsewhere (Banks 2005), it is not enough to provide technology to users but individuals in a particular community need to develop an understanding of 'the benefits and problems of any technology well enough to be able to critique, resist, and avoid them when necessary as well as using them when necessary' (p. 42). This can only be achieved through appropriate education, and here election experts play a crucial role in helping design education strategies so that users can understand the technology and tap into its full benefit.

From the evidence in this study, it is apparent that the EC and other stakeholders need to encourage wider consultations and broader community participation when new technologies are introduced for election management and for future elections. Ghana's diverse population, inequalities and different capabilities should be factored into implementing new and existing election technologies in order for the electorate to take ownership of the election process. 


\section{----- REFERENCES}

Afrobarometer 2016, 'Trust and Corruption in Public Institutions: Ghanaian Opinions', Available at www.afrobarometer.org.

Akpan, NE \& Adagba, SO 2018, 'Information Technology: A Contemporary Tool to Combat Electoral Fraud in Nigeria', International Journal of Social Sciences and Humanities Reviews, vol. 8, no. 1, pp. 78-87.

Asante, W \& Asare, BE 2017, 'Ghana's 2012 Election Petition and Its Outcome: A Giant Leap Towards Democratic Consolidation', in BE Asare \& AKD Frempong (eds), Selected Issues in Ghana's Democracy Vol. 1, Digibooks Ghana Ltd., Tema.

Asante, W 2008, Election Management and Democratic Growth: The Case of the Electoral Commission of Ghana, BA Dissertation, University of Ghana, Accra.

Ashenfelter, O \& Kelley, S Jr. 1975, 'Determinants of participation in Presidential elections', Journal of Law and Economics, vol. 18, pp. 695-733.

Ayee, JRA 1997, 'Election Management and Democratic Consolidation: The Case of Electoral Commission of Ghana', in JRA Ayee (ed), The 1996 General Elections and Democratic Consolidation, Department of Political Science, Accra.

Banks, AJ 2005, Race, rhetoric, and technology: Searching for higher ground, Routledge.

Barzel, Y \& Silberberg, E 1973, 'Is the act of voting rational?', Public Choice, vol. 16, pp. 51-58.

Bening, RB 2012, 'The Creation of Districts and Constituencies in Ghana: Some Pertinent Issues in the Current Dispensation', Ghana Journal of Geography, vol. 4, pp. 1-17.

Boafo-Arthur, K 1995, 'Managing Inter-Party Conflict in Ghanaian Politics: Lessons from the National Democratic Congress and the New Patriotic Party (NPP) Dialogue', in M Oquaye (ed), Democracy and Conflict Resolution in Ghana, Gold-Type Publications Limited, Accra.

Boateng, KA \& Akaba, M 2015, 'Computerising the Voting Process: On the Difficulties and Benefits of Biometric Verification Elections', Lecture Notes on Software Engineering, vol. 3, no. 1, pp. 67-72.

Botchway, TP \& Kwarteng, AH 2018, 'Electoral Reforms and Democratic Consolidation in Ghana: An Analysis of the Role of the Electoral Commission in the Fourth Republic (1992-2016)', Asian Research Journal of Arts \& Social Sciences, vol. 5, no. 3, pp. 1-12.

Bryman, A 2012, Social Research Methods, Oxford University Press, Oxford.

Card, D \& Moretti, E 2007, 'Does voting technology affect election outcomes? Touch-screen voting and the 2004 Presidential election', Review of Economics and Statistics, vol. 89, no. 4, pp. 660-673.

Creswell, JW 2007, Qualitative Inquiry and Research Design: Choosing Among Five Approaches, $2^{\text {nd }}$ ed, Sage Publications Inc., Thousand Oaks. 
Debrah, E 2015, 'Reforming Ghana's Electoral Process: Lessons and the Way Forward', Journal of Politics and Law, vol. 8, no. 1, pp. 1-13.

Dorpenyo, IK 2016, Unblackboxing Technology Through the Rhetoric of Technical Communication: Biometric Technology and Ghana's 2012 Elections, PhD Dissertation, Michigan Technological University, Michigan.

Effah, J \& Debrah, E 2018, 'Biometric technology for voter identification: The experience in Ghana', The Information Society, vol. 34, no. 2, 104-113. DOI:10.1080 /01972243.2017.1414720

Farber, SH 2009, 'Increasing Voter Turnout: Is Democracy Day the Answer?', CEPS Working Paper, no. 181, pp. 1-19.

Filer, JE \& Kenny, LW 1980, 'Voter turnout and the benefits of voting', Public Choice, vol. 35, pp. 575-585.

Filer, JE, Kenny, LW \& Morton, R 1991, 'Voting laws, educational policies, and minority turnout', Journal of Law and Economics, vol. 34, pp. 371-394.

Frempong, AKD 2008, 'Innovations in Electoral Politics in Ghana's Fourth Republic: An Analysis', in C Raventos, (ed), Democratic Innovation in the South: Participation and Representation in Asia, Africa and Latin America, CLASCO Books, Buenos Aires.

Frempong, AKD 2015, 'Elections in Ghana (1951 - 2012)', Life @ 60 Publishers, Accra. Ghana Statistical Service 2013, 2010 Population and Housing Census: National Analytical Report, Government of Ghana, Accra.

GhanaStatisticalService2014,2010Populationand Housing Census Report:Urbanization in Ghana, Available at<www.statsghana.gov.gh/docfiles/2010phc/Mono/ Urbanisation in Ghana.pdf > [ 16 May 2018]

Gelb, A \& Diofasi, A 2016, 'Biometric Elections in Poor Countries: Wasteful or a Worthwhile Investment?' Working Paper 435, Center for Global Development, Available at $<$ www.cgdev.org $>$ (6 May 2018).

Golden, M, Kramon, E \& Ofosu, G 2014, Electoral Fraud and Biometric Identification Machine Failure in a Competitive Democracy, Paper Presented at the Annual Meeting of the American Political Science Association, August 28-31, Washington, DC.

Gyekye-Jandoh, MAA 2013, 'Electoral reform and gradual democratization in Africa: The case of Ghana', African Journal of Social Sciences, pp. 74-92.

Hennink, M, Hutter, I \& Bailey, A 2011, Qualitative Research Methods, Sage Publications Ltd., Los Angeles/London.

Hobbis, SK \& Hobbis, G 2017, 'Voter Integrity, Trust and the Promise of Digital Technologies: Biometric Voter Registration in Solomon Islands', Anthropological Forum, vol. 27, no. 2, pp. 114-134, DOI: 10.1080/00664677.2017.1324287

Hsieh, H-F \& Shannon, SE 2005, 'Three Approaches to Qualitative Content Analysis', Qualitative Health Research, vol. 15, no. 9, pp. 1277-1288. 
IDEA 2006, 'Reforming Electoral Processes', in IIDEA, Electoral Management Design: The International IDEA Handbook, International Institute, Stockholm, Sweden.

International IDEA 2017, Introducing Biometric Technology in Elections, International Institute for Democracy and Electoral Assistance, Stockholm.

Jackson, LA 2009, 'Biometric Technology: The future of assurance and authentication in the lodging industry', International Journal of Contemporary Hospitality Management, vol. 21, pp. 892-905.

Knack, S 1994, 'Does rain help the Republicans? Theory and evidence on turnout and the vote', Public Choice, vol. 79, pp. 187-209.

Magnet, S 2011, When biometrics fail: Gender, race, and the technology of identity, Duke University Press, Durham, North Carolina.

Matsusaka, J 1993, 'Election closeness and voter turnout: Evidence from California ballot propositions', Public Choice, vol. 76, pp. 313-334.

Mugica, A 2015, 'The Case for Election Technology', European View, vol. 14, pp. 111-19.

Nwangwu, C 2015, Biometric Voting Technology and the 2015 General Elections in Nigeria, Paper Presented at Two-Day National Conference on 'The 2015 General Elections in Nigeria: The Real Issues' organized by The Electoral Institute 27th and 28th July.

Olurode, L 2017, 'Technology and Election Conundrum: A Case Study of Nigeria' Sociology and Anthropology, vol. 5, no. 10, pp. 799-811.

Riker, W \& Ordeshook, PC 1968, 'A Theory of the Calculus of Voting', American Political Science Review, vol. 62, no. 1, pp. 25-42.

Roseman, Jr., GH \& Stephenson, EF 2005, 'The Effect of Voting Technology on Voter Turnout: Do Computers Scare the Elderly?', Public Choice, vol. 123, pp. 39-47.

Rosenberg, JS \& Chen, M 2009, Expanding Democracy: Voter Registration around the World, Brennan Center for Justice at New York University School of Law, Available at <http://brennan.3cdn.net/3234b49c4234d92bf3_3km6i2ifu. pdf $>$ [10 May 2015].

Shachar, R \& Nalebuff, B 1999, 'Follow the leader: Theory and evidence on political participation', American Economic Review, vol. 89, pp. 525-547.

Slack, JD \& Wise, JM 2005, Culture+ technology: A primer, Peter Lang Publishing Group, Bern.

Uludag, U, Pankanti, S, Prabhakhar, S \& Jain, AK 2004, 'Biometric Cryptosystems: Issues and Challenges', Proceedings of the IEEE, vol. 92, pp. 948-960.

Winner, L 1989, The Whale and the Reactor: A Search for Limits in an Age of High Technology, University of Chicago Press, Chicago. 


\title{
THE LIMITS OF PEACE JOURNALISM Media Reportage of Kenya's 2017 General Elections
}

\section{Joseph Olusegun Adebayo and Blessing Makwambeni}

\author{
Joseph Olusegun Adebayo is a postdoctoral research fellow, \\ Journalism and Media Studies Department, Cape Peninsula University of \\ Technology, Cape Town
Blessing Makwambeni is a Senior Lecturer, Research \& Postgraduate Coordinator, Media Department Public Relations Programme, Cape Peninsula University of Technology, Cape Town

\begin{abstract}
In 2008, Kenya hovered on the brink of a war arising from the political violence that followed the general elections. In reportage akin to that of the infamous Rwandan genocide of 1994, the Kenyan media pitched the country's different ethnoreligious groups against each other. The result was a wanton loss of lives and property, as well as a highly volatile socio-political climate. By 2013 when the country was about to conduct another general election, apprehension ran high amongst the populace. However, in what seemed like a sharp deviation from what had happened in 2008, media reportage of the election was more conflict-sensitive. Although there were pockets of irregularities, the 2013 election recorded less violence and the media was lauded as a key reason for that. In the 2017 election, the media was once again at the centre of public discourse, this time accused of sacrificing democracy in the cause of peace. Public observers accused the media of downplaying and/ or underreporting irregularities and outright election rigging for fear of a possible outbreak of violence. The argument by many journalists and media practitioners was that the media practised peace journalism. By analysing selected articles from Kenya's mainstream media, this article examines peace journalism in its many complexities and contextual dynamics, in order to clarify the thin line between peace journalism and advocacy.
\end{abstract}

Keywords: elections, framing, media, media framing, peace journalism, election reportage. 


\section{BACKGROUND}

Kenya has a vibrant media sector which is often regarded as one of Africa's most vociferous (Adebayo 2016). From the early colonial days when the British started newspapers such as the Taveta Chronicle, established in 1895 by Rev. Robert Stegal of the Church Missionary Society, and the founding of the Leader by the British East African Company in 1899, the media has played an active role in setting the agenda for public discourse. The Kenyan media has served varying functions: it has been both a means to maintain the status quo by legitimising the rights of the colonial government, and in later days a tool for social rebirth, the promotion of human rights, and the provision of forums for public debate (Ojwang 2009).

One area where the Kenyan media has been particularly active is in the electoral process. In the last decade the country has had three elections, with the media playing a pivotal role in all, most notably in 2007 when Kenya experienced one of the worst explosions of post-election violence since independence. The conflict that ensued after the election results were announced was due in part to the ethnic, religious and tribal nature of Kenyan politics, as well as to uncontrolled media reportage (Youngblood 2018). Ojwang (2009, p.24) posits that the violence was precipitated by heightened expectations, exaggerated pre-election opinion polls and media reports of alleged rigging. In the run-up to the 2007 general election, the Kenyan public depended heavily on the media for information regarding the electoral process and candidates involved. To the media's credit, it provided live updates at the national vote-tallying centre, and set the tempo of public interest as a national conflict unfolded amid finger-pointing and grandstanding by political party loyalists.

According to Stremlau, Blanchard, Gabobe, and Ahmed (2009, p.18), the Kenyan media wittingly or unwittingly incited the public to violence, with attendant and avoidable loss of lives and property. Radio broadcasts shortly after the election contributed in no small measure to fuelling the post-election violence that rocked the country. Stremlau et al. observed that the major culprits were the vernacular radio stations, which broadcast in Luo, Kikuyu, Kalenjin, and other local languages. These stations overtly broadcast hate messages similar to those transmitted during the 1994 genocide in Rwanda. The mainstream English media in Kenya seemed determined to remain unbiased as its messages were largely objective, while the vernacular stations fuelled the embers of hatred and division (Stremlau et al., 2009).

Thus, in the lead-up to the 2013 general elections in Kenya there was considerable public apprehension as many were unsure about whether this election would also be violent. Given that the media was partly blamed for the violence that marred the 2008 elections, many wondered what role the media 
would play this time. Laker and Wanzala $(2012$, p.7) aver that training and retraining programmes were conducted for journalists in Kenya in a bid to forestall a recurrence of the violence that had engulfed the country in 2007. For example, the Peace Journalism Foundation (PJF), an East African-based peace media NGO with the aim of creating a peaceful society through the media, conducted training for Kenyan journalists in the runoff to the elections. Similarly, several other organisations such as the International Media Support Group conducted training for Kenyan journalists with the aim of ensuring that they were safe during elections and that they were able to provide balanced and fair reportage by using a conflict-sensitive style of journalism (Laker \& Wanzala, 2012).

While the 2013 general election in Kenya was in no way perfect, it was a marked improvement on the violent 2007 election. The media played a more responsible role in 2013 by mobilising and sensitising the public towards peace and nonviolence.

Kenya's next election was in 2017 and like the elections of 2008 and 2013, the media played an active role before, during and after the electoral process. The election was widely considered to be one of the most contentious, not only in Kenya but also across the African continent. Although eight candidates, including three independent aspirants, vied for the presidency, it was clearly a contest between incumbent President Uhuru Kenyatta of the Jubilee Party of Kenya and Mr Raila Odinga of the National Super Alliance. The media's role in the election once more highlighted the contestations regarding peace journalism's propensity to unwittingly slide into advocacy. Renowned peace journalist Steven Youngblood describes the inclination of some journalists to (un)wittingly slide into advocacy and misrepresent peace journalism thus:

Nowhere in the theories of peace journalism elaborated by its founders, Dr Johan Galtung, Dr Jake Lynch, and Annabel McGoldrick, and nowhere in my new university textbook Peace Journalism Principles and Practices, does anyone say that peace journalists should ignore the unpleasant and potentially volatile news. 'Tension and protests' are newsworthy, and must be covered. Election rigging is news, and cannot be ignored by real journalists. Peace journalism does not question if these stories should be reported but instead asks how journalists should cover this news. Do we report responsibly and in a manner that does not incite violence, or in ways that fuel the fire and exacerbate an already tense situation?

(Youngblood 2018, p. 441)

According to Youngblood (ibid.), if the media in Kenya or elsewhere ignore or minimise news at the excuse of promoting peace, then they are not practising 
peace journalism - or any real journalism for that matter. This article argues that although there were dissensions raised regarding the Kenyan media's reportage of the 2017 elections (some of them very valid), this reportage consisted mainly of peace journalism in intention and principle. This study concurs with Youngblood and contends that, if in a bid to promote peace we foster injustice, we have actually done more disservice to society. The study further draws lessons that accrue from the Kenyan experience for other African countries planning to hold elections in the near future.

\section{THE PEACE JOURNALISM MODEL}

In the 1970s renowned Austrian scholar Johan Galtung first coined the term 'peace journalism' (PJ). According to Lynch and McGoldrick (2005, p.5), peace journalism is the deliberate selection and reportage of stories in ways that create opportunities for society to consider and value non-violent responses to conflict. Peace journalism uses the insights of conflict analysis and transformation to update concepts of balance, fairness, and accuracy in reporting; and provides a new route map tracing the connections between journalists, their sources, the stories they cover and the consequences of their journalism. In the process PJ builds an awareness of nonviolence and creativity in the practical job of everyday reporting and editing.

Hyde-Clarke (2011, p. 43) contends that one main feature of peace journalism is its ability to frame stories in ways that provide society with enough information with which to respond non-violently to conflict or conflict situations. She also affirms that peace journalism is not only relevant in conflict situations; it can also find relevance in attempts at maintaining peace in society by providing varied viewpoints that will help a large section of the citizenry make informed decisions about issues that concern them. This places enormous responsibilities on the media as society's watchdogs (Hyde-Clarke 2011, p.43).

Bratic, Ross, and Kang-Graham (2008, p.13) aver that peace journalism was born out of the need to correct the negative consequences associated with traditional (standard) journalism. They posit that the practice of traditional journalism is more likely to foster violent conflict than encourage peace because it does not present society with alternatives that encourage peace. This follows from the fact that news media have often been used to promote wars and conflicts. For example, the news media was accused of both helping the Allies further their goals in World War II, and (in Germany) overtly persuading the German masses into believing that Jews were a lesser race (Stout 2011, p.9). In addition, Nazi Germany employed undisguised propaganda to maintain the loyalty of Germans. In much the same way as the horrific genocide perpetrated by the Third 
Reich was encouraged by this prejudice, the media played a significant role in the ethnic conflicts that engulfed Rwanda and the former Yugoslavia by demonising the 'other' - Jew, Tutsis or Bosnian Muslims. Journalists played crucial roles in the promotion of violence in these countries (Thompson 2007).

The media can also play an important role in positively shaping society. Hachten $(2005$, p.24) states that the persistent reporting by the international media about pariah states such as South Africa under apartheid helped facilitate political change. Such reporting formed world opinions, which in turn led to actions by concerned nations. Persistent American and European press reports of the civil war in Bosnia and the growing evidence of genocide by Bosnian Serbs undoubtedly pushed the Clinton administration and NATO to intervene and impose a military truce, which ultimately led to peace in that troubled nation. Hackett (2010, p.118) argues that shifting and expanding the sphere of conflict reportage beyond the immediate conflict environment to larger venues, and thereby providing insight into possible causes, instigators and solutions, is one of the notable achievements of peace journalism.

However, this model is not without its criticisms; even its name evokes contention. For example, Loyn (2007, p.2) contends that the biggest problem with peace journalism is where it puts the reporter. He asserts that the primary duty of a reporter is to be an observer and not a participant in a conflict situation, or indeed, any issue of social relevance. According to Loyn, the reporter is not there to make peace or to take sides in a dispute, but to address and explain the complexity of a messy world and construct a narrative.

Similarly, Hanitzsch (2007, p.5) argues that the idea behind peace journalism is often based on an individualistic and voluntarist illusion which suggests that journalists only need to change their attitudes and behaviour in order to produce coverage that will embrace the tenets of peace journalism. He further contends that there are many structural constraints such as inadequate personnel, availability of sources, access to the scene and information in general, which shape and limit the work of journalists. Therefore, he affirms, it would be imprudent to suggest that the conduct of peace journalism is solely a matter of individual scope.

In defence of this model, Lynch and McGoldrick (2005) maintain that peace journalism is often misunderstood as 'advocating for peace'. Rather, they aver, it is a journalism model concerned with giving peace a chance in the national and international debate, by ensuring that nonviolent responses to conflict get a fair hearing. Similarly, Peleg (2007, p.3) faults Loyn's position that reporters should maintain objectivity by acting as detached observers and not players in the social sphere. He remarks that it is callous, inconceivable and insensitive for journalists to remain aloof and disconnected in the face of social injustice and tyranny. He is of the opinion that it is near-impossible to report on disasters such as the Rwandan 
genocide, the war in the DRC, and the ravaging scourge of HIV/AIDS without empathy and a distinct emotional slant.

Peleg also disagrees with Hanitzsch's (2007, p.5) position that peace journalism overemphasises voluntarism and individualism, ignoring the sustaining background, organisational logic and economic pressures that accompany day-to-day journalistic duties. Individual reporters, according to Hanitzsch, work alongside a group of other peace-minded people or groups to ensure peace, as they cannot possibly work alone or in a vacuum. According to Peleg (2007, p.4), peace journalism aims at individuals as agents of change and not as the solo crusaders proposed by Hanitzsch. The aim is to create a critical mass of individuals with innovative mindsets working towards the adoption of journalism, thereby rendering the tenets of peace journalism commonplace and not simply a passing fad.

A major criticism of peace journalism is that it inhibits journalists from practising fair and objective reporting. Fairness and objectivity are the universally accepted tenets of the journalism profession (Lee, 2010). Without objectivity, journalism loses respect. However, objectivity without sensitive reportage can often be the bane of journalism. As Lee (2010, p. 363) points out, objectivity is possibly one of the biggest obstacles to journalists playing a more responsible and beneficial role in public life. Objectivity, by emphasising facts and manifest events, devalues ideas, fragments experience and makes complex social phenomena more difficult to understand. Hackett (2010, p.180) notes that there are certain positive connotations associated with the term objectivity, such as fairness and the pursuit of truth without favour. He argues, however, that objectivity is not fixed but is relative, because whether or not objectivity is a desirable and achievable goal for reporting in a democratic society is debatable.

While objectivity should be entrenched as a fundamental aspect of journalism, it is vital nonetheless to note that news said to be objective can, in fact, fuel violence. Lynch and McGoldrick (2005, p. 209) identify the following ways in which news said to be objective fuels violence:

- News that overtly favours official sources

- News that is obviously biased in favour of events over the process

- News that favours dualism in reporting conflicts.

\section{METHOD}

For this study, the researcher analysed selected election-related news stories in two leading Kenyan newspapers, as per the 2015 GeoPoll data on newspaper and magazine readership in Kenya. According to the report, Daily 
Nation and Standard are the top newspapers by audience size and share, beating their competitors by a large margin. The report shows that Daily Nation had an average readership of approximately 4379400 per day, and Standard had an average of 2223500 per day. This means that nationwide, Daily Nation has a $40 \%$ share while Standard has a $20 \%$ share. Lower down, Taifa Leo has a $10 \%$ share, and People Daily has an $8 \%$ share (Elliott 2015).

Table 1 Daily Nation vs Standard readership in Kenya

\begin{tabular}{|l|c|c|c|}
\hline Newspaper & $\begin{array}{c}\text { Readers per day } \\
\text { (approximate) }\end{array}$ & $\begin{array}{c}\text { Average share } \\
\mathbf{( \% )}\end{array}$ & $\begin{array}{c}\text { Share among youth } \\
\mathbf{( \% )}\end{array}$ \\
\hline Daily Nation & 4379400 & 40 & 32 \\
\hline Standard & 2223500 & 20 & 19 \\
\hline
\end{tabular}

Source: Geopoll survey 2015

Suffice to add that the focus of the researcher's analysis was online newspapers; broadcast media outfits (radio and television) were not analysed. The reason for the choice of newspapers over broadcast media is due to the continued influence that traditional newspapers have in setting agenda for members of the public. As can be observed from Table 1 above, while the prevalence of social media and blogs have surged as sources of news, traditional newspapers still have a prominent place in news dissemination. In fact, studies by Jo (2005) and Anderson (2007) have shown that newspapers are generally perceived as more credible sources of news than online sources (social media). As Just et al. (1996, p. 31) aver, 'If a citizen wanted information about the substance of policies, newspapers were clearly the medium of choice'.

\section{TIME FRAME}

Kenya's general elections to elect the president, members of Parliament and devolved governments took place on 8 August 2017. Thus, the researcher focused the analysis on the period between January and August 2017, and also shortly after the election, from September to December 2017.

\section{FINDINGS}

What Peace Journalism is not: Lessons from the 2017 Kenyan Elections

Since contestations about what peace journalism is have not reconciled divergent and sometimes antagonistic opinions, a discussion of what peace journalism is not 
may provide a better understanding of the model. Nowhere in recent times have the tenets of peace journalism been questioned as much as in the 2017 Kenyan elections. Through analysis of selected newspaper stories that emanated from the country before, during and after the elections, this study aims to illustrate the limits of peace journalism.

\section{Peace Journalism is not a Conscious Disparaging of Journalistic Objectivity}

A major criticism of peace journalism is that it inhibits journalists from practising fair and objective reporting (Hanitzsch 2007; Loyn 2007). Critics argue that fairness and objectivity are the universally accepted tenets of professional journalism and many believe that without objectivity journalism loses its respect. However, objectivity without sensitive reportage can also be the bane of journalism. As Lee (2010) points out, objectivity is possibly one of the major obstacles to journalists playing a more responsible and beneficial role in public life. By emphasising facts and overt events, objectivity may devalue ideas, fragment experience and make complex social phenomena more difficult to understand. There are certain positive connotations associated with the term objectivity, such as fairness and the pursuit of truth without favour. However, objectivity is not a fixed position; it is relative because whether or not objectivity is a desirable and attainable goal for reporting in a democratic society remains debatable (Lee 2010).

In the wake of the prolonged and highly contested 2017 presidential election in Kenya, there have been intense debates within the media and sociopolitical circles about the role(s) the media played in the elections (Gathara 2017; Youngblood 2017). These debates have revolved around whether the media lived up to public expectations by reporting the entire election process accurately in an in-depth and fair manner that offered adequate space to the contesting parties, especially the fierce competition between the two major political formations, Raila Odinga's National Super Alliance (NASA) and the Jubilee Party led by Uhuru Kenyatta. The debate is whether the media served the broader national good, identifying and prioritising key national issues and presenting, analysing and projecting them in a manner that helps in the country's democratic transformation and in conflict resolution.

Shortly after the results of the 2017 general elections in Kenya were released, Raila Odinga, leader of the opposition party NASA, rejected and challenged the results. This led to a boycott of the repeat elections of October 2017 ordered by Kenya's courts. Mr Odinga cited several irregularities as reasons for his and his party's positions, including media bias, which was evident in deliberate misinformation, downplaying violent attacks on his supporters, and underreportage of his party's activities. He subsequently threatened to establish a 
'people's assembly' to carry out protests and boycotts, while seeking changes to the Constitution. In a column in the Washington Post on 11 August 2017, renowned Kenyan journalist, activist and cartoonist Patrick Gathara recalled that in the run-up to the election, there was great public resistance to 'preaching peace' as a means of pre-empting violence in the event that the election was disrupted (Gathara 2017). Gathara claimed that the media's bid to preach peace had the obverse effect and created the fear of possible anarchy in the minds of Kenyans. Wittingly or unwittingly they (the media) had made a deal with the government to report in ways that framed the election as free and fair (Gathara 2017).

While not discounting Gathara's views, given that media messages often hold varying meanings to different audiences depending on how the messages are framed, it is nonetheless important to point out that the media's watchdog role also includes providing early warnings for possible conflict situations. The sampled newspapers did just that. For example, The Daily Nation of 10 June 2017 had the following heading for its leading story: 'Insulating the 2017 election against violent extremism' (Kagwanja 2017). The article, which examined a report in 2017 by the International Crisis Group (ICG) called for vigilance from all Kenyans, and especially the security forces. The paper further remarked:

...What is patently clear, however, is that a necessary pathway to peace and to defeating the forces of extremism is to anchor democracy on a professionally robust, adequately financed and well-coordinated and equipped security sector...This is the most decisive lesson Kenya learnt from the 1991-2014 decades when protracted democratic transitions greatly weakened the coordination, control and mechanisms of its security forces... The government should invest in training and equipping the police in non-violent methods that de-escalate crises and counter extremism without violating human rights.

(Daily Nation, 10 June 2017)

When newspapers provide early warnings and calls for peace, it would be unfair to regard these as preaching peace. A crucial example of the importance of the media's early warning responsibility is the Rwandan genocide. In the lead up to what is today regarded as one of the most gruesome events of the 20th century, Dowden (2007) remarks that the media failed to report on the festering relationships and brewing animosity between Rwanda's ethnic groups.

Rwanda simply was not important enough. To British editors, it was a small country far away in a continent that rarely hit the headlines. The words Hutu and Tutsi sounded funny, hardly names that an ambitious news editor or desk officer would want to draw to the attention of a 
busy boss and claim that they were of immediate and vital importance. Within a few days of the plane crash, [which marked the start of the genocide] the Times ran several articles about what it obviously considered an angle to interest its readers: the fate of the Rwandan gorillas.

(Dowden 2007, p. 251)

While peace journalism seeks to promote public knowledge and understanding of alternatives to violence as means of resolving differences, it nonetheless does not mean that the public should not be made aware of the whole story in news items. Withholding or hiding stories lest these instigate public violence is in itself a form of violence. Deliberate misinformation or concealment of information is violent because ignorance can breed deadlier forms of violence.

In similar vein, shortly after the election the Standard newspaper presented a balanced analysis of some of the factors that led to the annulment of the 2017 Kenyan election. On 20 September 2017, the newspaper published a story titled: 'Reasons why presidential election was declared invalid, court gives full verdict'. Although the story was largely a summary of the Supreme Court's verdict on the disputed election, the newspaper provided a detailed analysis of this verdict. The claims by both the incumbent, President Uhuru Kenyatta, and his main opponent, Mr Raila Odinga were presented. The newspaper also highlighted the shortcomings of the Independent Electoral and Boundaries Commission (IEBC), stating that the body failed to act on the violation of law and misuse of public resources by Uhuru Kenyatta during campaigns. The newspaper gave voices to the major actors, and apportioned blame where necessary. This balanced presentation of varying viewpoints with adequate context and background to social issues represents the ideal of what peace journalism should be.

\section{Peace Journalism is not 'Good News' Journalism}

There is a general belief that news is not news until it is bad. When the then BBC newsreader Martin Lewis suggested in 1993 that television news coverage should move away from bad news and 'its remorseless emphasis on disaster, conflict and failure' (Independent 26 April 1993) to more good news stories, particularly on television but also in newspapers, he was derided by his colleagues and, according to him, was even threatened with dismissal by his employers. Recounting his experience years later, Lewis remarked:

...My job was on the line. I thought - 'Here is an organization respected around the world, the bastion of democratic debate and argument 
and assumes the right - quite properly - to analyse and criticise every other sector in society, but they won't tolerate a public discussion about [how] they operate their own news business and indeed the news business itself.

Lewis's experience would be different today as many news organisations have begun to consider tilting their reportage towards 'good' news over 'bad' news. DigiDay, an online trade magazine that creates content, services, and community fostering change in media and communication, reports that Huffington Post's Good News has increased its traffic 85 percent over the last year and gets twice the social referrals of other Huffington Post content (Sahil 2016). Given the growth of social media and its increasing importance as a tool for business growth and development, one can safely state that good news is good business for the Huffington Post. Other publishers of positive news aver that countering traditional media's penchant for bad news is not only good for societal well-being; it also helps to catalyse potential solutions to the problems of society (Sahil 2016). However, it is important to state that good journalism is not peace journalism; and the sampled Kenyan newspapers aptly made this distinction in their reportage.

Many critics of the Kenyan media reportage of the 2017 Kenyan general elections, like Gathara, contend that the Kenya media painted a façade of normality by ignoring or under-reporting citizens' protests and frustrations in order not to disturb the peace. Some also argue that most of Kenya's media saw the reportage of peaceful marches and public protests as bad news that might paint the nation in bad light in the international community, and might also initiate violence. According to Ouma (2018), the Kenyan mainstream media blacked out the clashes between state security agencies and sections of opposition supporters who were demonstrating against the disputed presidential results. Ouma further argued that the local mainstream media attempted to paint an image of a country that had moved on from the electoral conflict, and instead they focussed on other trivialities (Ouma, 2018).

Claims that the Kenyan media 'blacked out' certain stories which they believed might incite violence are not completely true, judging by the news stories that were analysed. For example, the story by Onyango in the Daily Nation of 9 October 2017 entitled ' 37 died in post-poll chaos - KNCHR report', gave a detailed report of the violence that ensued shortly after the general elections. The newspaper did not only present numbers, it humanised its story by providing the exact place where the violence and resultant deaths occurred:

The deaths were recorded in Kawangware, Mathare, Kibera, Lucky Summer, Baba Dogo and Huruma in Nairobi County; Kondele, 
Manyatta, Nyamasaria, Nyalenda in Kisumu County; Siaya town and Ugunja in Siaya County; Rangwe in Homa Bay County, Tana River and Elgeyo-Marakwet counties. 27 people were killed in Nairobi, Kisumu (3), Tana River (3), Siaya (2) and one each in Homa Bay and ElgeyoMarakwet counties.

(Daily Nation, 9 October 2017)

The newspaper also reported the ages of the dead and that seven minors had died, three girls and four boys. The paper went a step further by naming the toddler who lost her life to the violence as Samantha Pendo of Kisumu's Nyenda slum. Not only did the newspaper not blacklist stories of violence, it presented these in a way that humanised those affected. This is an important tenet of the peace journalism model, that is of humanising stories, and giving voice to the voiceless (Lynch \& McGoldrick 2005).

\section{Peace Journalism is not Advocacy}

At the core of peace journalism's belief is the tenet that any aware member of the society would be able to make informed decisions on the best possible ways to resolve an issue (Lynch \& McGoldrick 2005). Such awareness includes the various actors involved in a given conflict or conflict situation, the possible unseen influencers, the people who benefit and those who stand to lose from a conflict, men and women who are working for peaceful resolution of the conflict, as well as creating awareness of the possible nonviolent conflict resolution options available to all parties involved in the conflict. This involves not just reporting good news, or under-reporting bad news; it involves conscious engagement by the journalist in ways that give them the opportunity to understand contexts and backgrounds. These in turn would ultimately help by providing detailed coverage or reportage of events that present society with balanced information of all sides and all angles.

However, Loyn (2007), one of peace journalism's fiercest critics, maintains that his discontent with peace journalism stems from where it puts the reporter. He argues that by demanding engagement from the reporter, peace journalism fails to recognise or accept that there is no such thing as a transparent observer; the implied contract with the audience is that the standpoint of the reporter is at least an attempt to be an observer. He remarks that:

Reporting news is about addressing the complications of a messy, visceral world and constructing a narrative, telling stories, not 'searching under stones'. This may involve shining a light on some dark places, where the peace/solution-oriented seeker for conflict 
resolution would want to 'frame' the situation in a different way. But if people are out to kill each other then, as journalists, we are not there to stop them.

This study agrees with Loyn's position that in an attempt to practice peace journalism, many practitioners may (un)wittingly apply a prescriptive set of rules that actually excludes the engagements that peace journalism claims to promote.

Journalists in Kenya, like their counterparts in most part of the continent, face daunting tasks when it comes to discharging their duties. Some even argue that credit should be given to any journalist who reports at all, given the dangerous conditions they operate in. For example, a report by Article 19, an organisation committed to helping people (including journalists) express themselves freely and engage in public life without fear of discrimination, shows that journalists who covered Kenya's 2017 general elections worked in an exceptionally challenging environment. Many faced direct attacks and arrests, were denied access to certain areas, and received different forms of threats, even more so after the August elections and in the run-up to the October repeat presidential polls.

While it is commendable that the media in Kenya took intentional and deliberate steps to consciously report in ways that sought to foster peace and nonviolence during the 2017 elections, it is nonetheless important to note that deliberately avoiding or underreporting news reports or events, as argued by Gathara (2007), negated their efforts. News should be served to the public as a buffet. According to Kempf (2007), if peace journalism is understood in the right way, it is not the opposite of good journalism, but its prerequisite.

\section{CONCLUSION}

The aim of the article was not to defend Kenyan media's reportage of the 2017 elections, neither was it an approval for another peace journalism success story. The study sought to provide balance, through an analysis of examples from Kenya's mainstream media, to the ongoing debate on the role played by the Kenyan media in the 2017 election. Critics argue that the media sacrificed professionality for peace, and that the media 'went to bed' with the government (Gathara, 2017).

While the arguments that the media underreported the election may in some respects be true, it is however unfair to generalise this as the story of media reportage of Kenya's 2017 elections. The Kenyan media has played active roles in most elections in the country, and has been either praised or condemned for its role. It is safe to say that the media in Kenya is gradually beginning to develop a peace journalism approach that is unique to the Kenyan sociocultural and sociopolitical milieu. There will inevitably be contentions with the media's approach. Firstly, 
accusations of media complicity or 'sell out' will depend largely on who is making the allegation, and on his or her political leanings. Due to the propensity of most Kenyans (and indeed in most parts of Africa) to view politicians and/or political parties from an ethnoreligious perspective, it is often easy to accuse the media of bias when stories do not favour their course.

The media in Africa is constantly under pressure from both the populace and the government. This is even more evident today as elections have increased on the continent because, as Cheeseman and Klass (2018) argue, authoritarian leaders have devised new strategies of rigging elections in ways that are harder for members of the public to see, to the extent that even the media wittingly or unwittingly ascribe legitimacy to often flawed electoral systems. Cheeseman and Klass assert that:

How is it possible that the flourishing of elections has coincided with a decade of democratic decline? The answer is that dictators, despots, and counterfeit democrats have figured out how to rig elections and get away with it. An increasing number of authoritarian leaders are contesting multiparty elections, but are unwilling to put their fate in the hands of voters; in other words, more elections are being held, but more elections are also being rigged.

(Cheeseman and Klass, 2018, p. 3)

Unfortunately, many journalists have ended up as pawns in their hands and have aided the fostering of illegality, which has the potential to snowball into direct violence (Adebayo, 2018). Critics of peace journalism like Loyn (2007, p.2) contend that the biggest problem with the model is where it puts the reporter. He asserts that the primary duty of a reporter is to be an observer and not a participant in a conflict situation, or indeed, any issue of social relevance. According to Loyn, the reporter is not there to make peace but to address the complications of a messy world and construct a narrative, not to search for connotations. In other words, Loyn argues that journalists should report social issues such as elections without necessarily meddling in externalities such as peacemaking. In his words: 'It cannot be the function of journalism to mediate between conflict parties, to sit down at a negotiating table with them and moderate their disputes.'

Loyn's position resonates with those of Hanitzsch (2007) who avers that the peace journalism movement wittingly or unwittingly assumes that the media is all-powerful and that its effects are always causal and linear. He argues that this overestimates the power of journalism and understates the impact of interpersonal communication. According to Hanitzsch, this view connects readily with an anachronistic conceptualisation of the audience as a mass, as an 
aggregate composed of dispersed individuals whose characteristics are of only modest consequence for the understanding of mass communication. He argues that if such conceptualisation of the audience as a mass coincides with the demand for a (socially) responsible journalism, fatal misjudgements are difficult to avoid.

Although the researchers do not agree with the views of Loyn and Hanitzsch, they nonetheless reinforce the need for balance in the practice of peace journalism, and the need to understand its limits. Journalists practising peace journalism run the risk of unwittingly becoming advocates. As Youngblood (2018) asserts, none of the tenets of peace journalism suggests that news should be ignored or sugarcoated. He argues that considering the consequences of one's reporting does not mean setting aside or downplaying unpleasant or potentially inflammatory news. What it does mean is that peace journalists should take care to frame and word the story in such a way that, at a minimum, it does not exacerbate the situation. Journalists should not hold back certain facts, but they should not sensationalise them either. These facts should be presented alongside voices that offer nonviolent solutions.

\section{--_-- REFERENCES}

Adebayo, OJ 2018, 'The Impact of Peace Journalism Training on Journalists' Reportage of the 2015 Elections in Nigeria: An Action Research Case Study', Communicatio, South African Journal for Communication Theory and Research, vol.42, no 3, pp. 361-377.

Anderson, E 2007, Media usage of Journalism students of the University of MissouriColumbia, MA Thesis, University of Missouri-Columbia.

Article 19 2008, Kenya: Violations of Media Freedom, May 201-April 2018.

Asamba, M 2017, 'Reasons why presidential election was declared invalid, court gives full verdict', Standard [online]. Available: www.standardmedia.co.ke/ article / 2001255107 / reasons-why-presidential-election-was-declaredinvalid-court-gives-full-verdict [Accessed 13 June 2019].

Bratic, V, Ross, S \& Kang-Graham, H 2008, 'Bosnia's Open Broadcast Network: A brief but illustrative foray into peace journalism practice', Global media journal, vol. 7, no. 13, pp. 1-22.

Cheeseman, N \& Klass, B 2018, How to Rig an Election, Yale University Press, New Haven.

Dowden, R 2007, 'The media's failure: a reflection on the Rwanda genocide', in The media and the Rwanda genocide, ed. Alan Thompson, Pluto Press, London.

Elliot, R 2015, 'Data on Newspaper, Magazine Readership in Kenya', GeoPoll (online), Available: https://www.geopoll.com/blog/data-on-newspapermagazine-readership-in-kenya/ [Accessed: 05 June 2019]. 
Fisher, C 2016, 'The Advocacy Continuum: Towards a theory of Advocacy in Journalism', Journalism, vol. 17, no. 6, pp. 711-726.

Gathara, P2017, 'Kenya's elections show how themedia has sold its soul', Washington Post, August 11, 2017. Available: https://www.washingtonpost.com/ news / global-opinions/wp/2017/08/11/kenyas-elections-show-how-themedia-has-sold-its-soul/?noredirect=on\&utm_term $=$. a81805694ee6

Hackett, R 2010, 'Journalism for peace and justice: towards a comparative analysis of media paradigms', Studies in Social Science, vol. 4, no. 2, pp. 179-198.

Hachten, W 2005, The troubles of journalism, Lawrence Erlbaum Associates, New Jersey.

Hanitzsch, T 2007, 'Situating peace journalism in journalism practice: a critical appraisal', Conflict and communication online, vol. 6, no. 2, pp. 1-9.

Hyde-Clarke, N 2011, 'Political posturing and the need for peace journalism in South Africa: the case of Julius Malema', Communication online, vol. 37, no 1, pp. 41-55.

Jo, S 2005, 'The Effect of Online Media Credibility on Trust Relationships', Journal of Website Promotion, vol. 1, no 2, pp. 57-78.

Just, M, Crigler, A, Alger, D, Cook, T, Kern, M, \& West, D 1996, Crosstalk: Citizens, candidates, and the media in a presidential campaign, University of Chicago Press, Chicago, IL.

Kagwanja, P 2017, 'Insulating the 2017 election against violent extremism', The Daily Nation Newspaper [online]. Available: www.nation.co.ke/oped/ opinion/ Insulating-the-2017-election-against-violent-extremism/4408083965154-ufutp1/index.html [Accessed 11 June 2019].

Kempf, W 2007, 'Peace Journalism: A Tightrope walk between Advocacy Journalism and Constructive Conflict Coverage', Conflict $\mathcal{E}$ communication online, vol. 6, no 2, pp. 1-9. Available: http://www.cco.regener-online. de/2007_2/pdf/kempf.pdf

Laker, G \& Wanzala, O 2012, 'Kenya journalists learn to speak, write peace', The peace journalist (online), vol. 1, no. 2, pp.1-24. Available: www.park.edu/ peacecenter (Accessed: 12th April 2019).

Lee, S 2010, 'Peace journalism: principles and structural limitations in the news coverage of three conflicts', Mass communication and society, vol. 13, pp. 361384.

Loyn, D 2007, 'Good journalism or peace journalism? Counterplea by David Loyn', Conflict \& communication online, vol. 6, no. 2, pp. 1-6.

Lynch, J 2007, 'Peace journalism and its discontents', Conflict $\mathcal{E}$ communication online, vol. 6, no. 2, pp. 1-13.

McGoldrick, A 2006, 'War journalism and objectivity', Conflict and communication online, vol. 5, no. 2, pp. 1-7. Available: http://www.cco.regener-online. de/2006_2/pdf/mcgoldrick.pdf 
Ojwang, B 2009, 'The Semantics of Peace and the Role of the Print Media in the 2007-2008 Post-Election Violence in Kenya', Africa Media Review, vol. 17, no. 1, pp. 23-50.

Onyango, L 2017, '37 died in post-poll chaos-KNCHR Report', Daily Nation [online], Available: https: / / www.nation.co.ke/news/Death-toll-of-Kenyapost-election-violence-2017/1056-4131688-w6fc91/index.html [Accessed 12 June 2019].

Ouma, S 2018, 'Reporting for Democracy or Convenience? The Kenyan Media and the 2017 Elections', The Round Table, vol. 107, no. 2, pp. 173-188.

Peleg, S 2007, 'In defence of peace journalism: a rejoinder', Communication online (online), vol. 6, no. 2, pp. 1-9. Available: http:/ / www.park.edu/mobile/ center-for-peace-journalism/documents/resouces (Accessed: 16 April 2019).

Sahil, P 2016. 'Huffington Post finds feel good videos perform best on Facebook', March 23, 2016. Available: https:// digiday.com/media/huffington-postfinds-solution-oriented-videos-outperform-others-facebook /

Stout, M 2011, The effectiveness of Nazi propaganda during World War II (Online). MA Thesis, Eastern Michigan University. Available: http://commons.emich. edu/theses [Accessed: 3rd March 2019].

Stremlau, N, Blanchard, M, Gabobe, Y \& Ahmed, F 2009, The Role of the Media in the Upcoming Somaliland Elections: Lessons from Kenya (online). Oxford University Press, Oxford.

Thompson, A 2007, The media and the Rwandan genocide, Pluto Press, London.

Youngblood, S 2018, 'Kenyan Media Test Peace Journalism Principles', Peace Review: A Journal of Social Justice, vol. 29, pp. 440-442. 


\title{
ELECTORAL VIOLENCE IN KENYA 2007-2008 The Role of Vernacular Radio
}

\author{
Philip Onguny \\ Philip Onguny is Assistant Professor of Conflict Studies \\ Saint Paul University, Ottawa
}

\begin{abstract}
This article examines how the shifts in vernacular radio narratives influenced intergroup relations during the 2007-08 electoral violence in Kenya. Using media as an analytical framework, together with original in-depth interview data collected over four months of fieldwork in 2010, the article explores how vernacular radio listeners in Kisumu, Eldoret, and Nyeri interpreted the 2007-08 electoral violence prior to, during, and after the event. It argues that the framing of electoral stakes and subsequent violence by vernacular radio stations is mainly between differentiated and concerted frames, depending on the stage at which the violence manifests itself. Differentiated frames reinforce divisive and/or rebellious attitudes, and are likely to increase intergroup competition and further violence along ethnic lines. Concerted framing underpins the perceived areas of common interest believed to transcend disparate group allegiances, and this establishes the possibility of intergroup dialogue and collaborative attitudes. These findings also highlight the central role of ethno-linguistic proximity and ethno-regional polity as potential drivers of vernacular radio frames, particularly in situations of electoral violence.
\end{abstract}

Keywords: Kenya, media, framing, vernacular radio, ethnic conflicts, peacebuilding

\section{INTRODUCTION}

Kenya has recently witnessed a significant shift in its media landscape, in particular with the rapid growth of vernacular radio. While this increase may be applauded as one of the many efforts the country has made to reinforce political accountability and democratic liberties (Cottrell \& Ghai 2007), accommodating ethnic differences and interests remains a daunting task for media organisations. 
There are at least forty-two different ethno-linguistic groups in Kenya. Most are confined within specific regions such as Nyanza (Luo majority), Central (Kikuyu majority) and Rift Valley province (Kalenjin majority), all of which have recently been broken down into 47 counties. Further, the competitive nature of electoral processes in Kenya and recent proliferation of vernacular radio have served to strengthen ethno-political categorisation at the expense of national self-determination (Somerville 2009; Jamal \& Deane 2008).

Although the current media landscape may be seen in a positive light, the relationship between the state and media outlets has always been uncertain (Odhiambo 2002). According to Throup and Hornsby (1998), the changes that accompanied political revolutions in the 1990s served to encourage the growth of independent media even though the government attempted to control media content through impromptu media bills and regulations. These practices saw a gradual institutionalisation of critical media. However, as Wanyande (1995) points out, the winds of change did not stop the government from disciplining the media whenever it failed to toe the line. Electoral cycles and their aftermath have increased government's attempt to control media narratives on the grounds of curbing hate messages. In addition to the brown envelopes taken by some journalists and editors to kill certain stories (Helander 2010; Lohner, Banjac \& Neverla 2016), these actions have raised questions with regard to the linkages between media content and political agendas. Further, some studies have shown that the state has found a new way of influencing media content through advertisements in exchange for friendly coverage (Ogola 2011).

Media ownership is another factor that questions the links between media content and political interests. For instance, Royal Media Services, owned by businessman Samuel K. Macharia, controls most of the radio market in Kenya with fourteen different radio stations, most of which broadcast in local languages.

It is therefore not uncommon for politics and corporate interests to infiltrate electoral processes through media ownership. A number of vernacular radio stations were accused of fanning the intergroup polarisation believed to have sparked the 2007-08 electoral violence (Jamal \& Deane 2008). Accommodating intergroup interests during electoral processes became a major challenge for ethnic media, particularly vernacular radio. This may explain why the Kenyan government has, in the past, imposed a temporary ban on all live media under the umbrella of public safety (Zuckerman 2009; Somerville 2009; Jamal \& Deane 2008). A similar pattern was witnessed in 2018, when the government threatened to shut down media houses that planned a live broadcast of the mock swearingin of opposition leader Raila Odinga as the people's president (Waweru 2018).

While it is yet to be determined whether vernacular radio narratives did play an active part in influencing the 2007-08 electoral violence, studies have 
shown that media discourse significantly influences the public's attitudinal changes, particularly in political processes (Gower \& An 2009; Entman 2010; Zuckerman 2009). Previous patterns of ethno-political violence in Africa also support this assumption. Rwanda's widely cited genocide was partly blamed on Radio Television Libre des Mille Collines (RTLM) and the magazine Kangura for allegedly spreading hate messages that led to intergroup killings (Thomson 2007). The 1993 political violence in Burundi is also believed to have been influenced by media narratives circulated through Témoin-Nyabusorongo (Kaburahe 2004). The Democratic Republic of Congo's La Voix du Patriote was perceived as one of the catalysts for the ongoing civil war (Frère 2009). The confirmation of charges by the International Criminal Court (ICC) against Joshua Sang, one of Kenya's talk-show vernacular radio journalists, added to this growing concern. Although he was acquitted of all charges, Mr. Sang had been accused of broadcasting 'anti-Kikuyu rhetoric when Kalenjins who were largely in support of the Orange Democratic Movement party lost the election in 2007' (Chepkoech 2015).

These cases suggest that media discourse consists of controlled narratives with calculated outcomes (Barker \& Knight, 2000). The question is why electoral competitions often shift from electoral discourse to embrace ethnicity. This question is largely ignored. Little attention has been paid to the conditions that encourage vernacular radio listeners to participate in electoral violence despite numerous studies that have shown the role of radio in incentivising violence. Extant literature on the topic often emphasises ethno-political stigmatisation and how it affects the politics of democratisation (Frere 2009; Tomaselli \& Muller, 2001). While it is true that such categorisation may lead to the escalation or deescalation of violence, the frame-building process and how it influences intergroup attitudinal shifts during electoral violence remains largely unexplored.

Against this backdrop, the central question this study addresses is: How do vernacular radio stations accommodate and/or negotiate intergroup relations during periods of electoral violence, and why do electoral processes shift from electoral discussion to embrace ethnicity? To achieve this, this article draws on framing as an analytical scaffold and the 2007-08 election violence as a case study. It also uses original in-depth interviews conducted over a four-month period in three disparate ethno-linguistic regions in Kenya. It argues that the shifts (in vernacular radio frames) from electoral discourse to negative ethnicity is partly due to the systematic categorisation of ethnic groups into competitive ethnopolitical pacts. Ethno-linguistic affinity thus serves as a vehicle by which group interests are produced, negotiated, and consumed or contested. This negotiation and/or accommodation of intergroup relations is understood here in terms of concerted and differentiated vernacular radio frames. 


\section{CONCEPTUAL CLARIFICATIONS AND THEORETICAL FRAMEWORK}

Ethnicity is used here to highlight a 'decision people make to depict themselves or others symbolically as the bearers of certain cultural identity' (Cohen 1994, p. 119). According to Jenkins (2004), ethnicity is closely intertwined with selfhood (how you see yourself) and personhood (how others see you). Osaghae (1999) argues that these form the larger structure explaining intergroup relations in both conflict and collaboration. The term conflict is understood in this article as 'a situation in which two or more actors, who interact with each other, pursue incompatible goals, are aware of this incompatibility, and claim to be justified in the pursuit of their particular course of action' (Wolff 2004, p. 8). In this regard, goal incompatibility may generate wide-ranging sentiments such as discontent, aggression and assimilation.

The term vernacular radio is used for radio stations that broadcast in languages spoken by specific ethno-linguistic groups living in a multi-ethnic society where the politics of cultural hybridism is seemingly weakened by inter-ethnic interests and/or claims of ethnic essentialism. Vernacular radio stations often broadcast in non-official languages, although some societies are gradually recognising local dialects as official languages. This is the case in South Africa, where there have been eleven official spoken languages since 1994 (Lekgoathi 2012). The main particularity of vernacular radios is that they are likely to appropriate, customise and slant news for the specific groups they serve (Neyazi 2010).

Finally, the concept of framing is used to underpin the structures that help interpret perceived reality. Thus, media framing highlights the processes and structures of interpretation proposed through news storylines to reinforce a particular meaning with regard to the public perception of an occurrence (Gower \& An 2009). In this way, framing is essentially a matter of negotiation and salience.

The framing process thus provides the theoretical basis for the article. Early definitions of framing are often associated with Goffman's (1974) work, highlighting the cognitive structures that assist individual interpretation of perceived reality and/or social phenomena. According to Goffman, daily life experience not only structures our perceptions of social order, it organises and ritualises the representation of self in what he called 'staged performances'. In essence, Goffman's argument is that framing is a twofold process which, on the one hand, portrays self as a construct hinged on selective representations of reality, and on the other, mirrors individual interactions with the immediate environment. Frames, in this regard, reflect both the conscious state of mind (because individuals somehow manipulate situational norms to present their self in a controlled manner) and the unconscious (since a normalised social order limits the individual capacity to freely represent the self). 
Since Goffman's conception of framing is a continuous process of making sense, it has been widely appropriated in academic literature with varying definitions, depending on the field of study. For instance, communication scholars such as Entman (1993, p. 52) consider framing as a process whereby people identify 'some aspects of a perceived reality and make them more salient in a communicating text, in such a way as to promote a particular problem definition, causal interpretation, moral evaluation, and/or treatment recommendation'. More recently, scholars such as Matthes (2012) and D'Angelo (2011) have argued for an integrative approach to framing, suggesting that news frames not only disseminate persuasive angles of news interpretation, they also provide reasons why such frames are of great importance.

Scholars such as D'Angelo (2011) see framing as a dual concept whereby researchers bring together various angles of news analyses so they fit into a given conceptual frame of analysis. Thus, to understand the complexity of framing as a process, it is necessary to examine the selective processes that accompany the production and dissemination of news content (Matthes 2012; Entman 2010). Other communication scholars have also associated framing with priming and agenda-setting to emphasise the selective processes that alter audience perception and world views (Weaver 2007; Shah et al. 2009). At the core of these views is the assumption that media professionals 'construct the symbolic representations of society that members of the public use to make sense of events and issues' (Bronstein 2005, p. 785). Factors such as technological progress, journalistic orientation, financial pressure and corporate interest, are some of the conditions believed to influence media frames (Entman 2010).

Framing is also prevalent in mediation and negotiation literature, where it underscores the cognitive bargaining processes in which disputants weigh their gains or losses. Schweitzer, DeChurch and Gibson (2005, p. 2124) remind us that 'competitively framed negotiators tend to perceive their dispute as one in which one party gains at the other's expense, [while] cooperatively framed negotiators tend to perceive their dispute as an opportunity to create an integrative agreement that benefits both parties'. Understood as such, framing is fundamentally a communicative and integrative process poised on rhetorical structures and their degrees of congruence. This is predicated on the assumption that media representations are, above all, controlled narratives geared towards influencing public opinion, depending on their representational aptitudes (Lecheler \& de Vreese 2012).

From these perspectives, framing broadly represents a schema of interpretation socially constructed through news story lines to influence audience perception of a phenomenon (Tewksbury \& Scheufele 2009; Avraham \& First 2010). The argument is that social identity, including ethnic identity, is constructed on 
the group or collective frame of reference. This self-categorisation process is fluid and shifts depending on circumstances as was evident, for example, in the intense media coverage of the War on Terror (Simons 2008; Altheide 2009). The cultures of proximity often create a sense of solidarity and/or symbolic community based on perceived threats, interests, and expected outcomes (Kolmer \& Semetko 2009).

This brief overview of the framing perspective points to the duality inherent in vernacular radio coverage of competitive events such as elections in Africa, which often become ethnic. On the one hand is the need to understand the intricate relationship between framing as a persuasive discourse involving the strategic intentions of disputants; and on the other, framing is a communicative process exemplifying interpretive orientations (Kaufman \& Smith 1999). As an interpretative tool, framing can serve as a mental map allowing individuals to make sense of situations based on their own world views and lived experiences. This underscores the hegemonic power associated with media frames in political processes (El-Nawawy \& Powers 2010). As Entman (2010, p. 389) reminds us, 'slanted framing results from the interaction of real-world developments, cultural norms, and journalistic decision rules with the sometimes proficient and other times maladroit efforts of competing elites to manage the news'. It is along these lines that framing was adopted in this study as an analytical framework.

\section{METHODOLOGY AND CHOICE OF RESEARCH SITES}

The study draws primarily on in-depth interviews during four months of fieldwork in Kenya conducted in 2010 in three ethno-linguistic locations: Kisumu, Nyeri and Eldoret, selected for the following reasons:

Kisumu was targeted because the Luo, Kenya's third major ethnic group, are the dominant ethnic group. It is also close to Bondo, home to Raila Odinga, the former Prime Minister of Kenya and presidential candidate in the contentious 2007-08 elections as well as in 2013 and, unsuccessfully, in 2017. More importantly, Kisumu was among the worst affected areas during the 2007-08 post-election violence. It has often been regarded as a base for the country's opposition politics since the acrimonious political split between Jomo Kenyatta, Kenya's first president, and the then-vice-president, Jaramogi Oginga Odinga (father of Raila Odinga), in 1966.

Eldoret was selected because it is home to the Kalenjin, Kenya's fourth largest ethnic group. Eldoret is close to Kabarnet, home to the former head of state, Daniel T. Arap Moi, whose regime lasted for more than two decades (19782002). Eldoret was also one of the hot spots during the 2007-08 electoral violence, where individuals were burned alive inside the Kenya Assemblies of God Church building in Kiambaa (Rice 2008). Furthermore, William Ruto, then Eldoret North's member of parliament and subsequently deputy president, had been indicted 
by the International Criminal Court (ICC) for alleged crimes against humanity committed during the 2007-08 conflicts. Uhuru Kenyatta was similarly accused but was acquitted when the charges were dropped, became president in 2013 and was re-elected in 2018.

The third area, Nyeri, was considered a suitable research site because it is located in the former Central Province, mainly inhabited by the Kikuyu, Kenya's largest ethnic group according to the 2009 census. Nyeri is also close to Othaya, home to former president Mwai Kibaki whose controversial re-election sparked the 2007-08 electoral violence. In addition, the first president of Kenya, Jomo Kenyatta, and the fourth president, Uhuru Kenyatta, hail from Gatundu, also in the former Central Province.

Overall, the choice of these research sites was motivated by the dominant ethnic languages spoken, historical contingencies, and the impact that the 200708 election violence had on ethno-linguistic populations in these locations, as reported by Human Rights Watch (2009). One of the limitations facing the study was that it relied on reported accounts of vernacular radio listeners in the target ethno-linguistic locations as a means to identify the dominant views that may have been advanced before, during, and after the 2007-08 electoral violence. This is because radio recordings were not accessible for analysis, as there were parallel ICC-led investigations taking place during the time of the fieldwork (June-September 2010). Several broadcasters were unwilling to provide access to their recordings.

Further, since the study targeted specific ethno-linguistic regions (and related vernacular radios), it did not generalise its findings. The results presented are therefore meant to offer the possibility of studying other regions to determine whether or not similar patterns of frames may emerge during electoral violence. The study also relied on a total of 45 respondents, 15 in-depth interviews per location across different demographics. Recruitment criteria included the completion of primary education and a comprehensive knowledge of English, to avoid translated materials that might not reflect respondents' opinions. Finally, target respondents needed to reflect the study's target groups: Luo, Kalenjin and Kikuyu. Frame clusters were then generated from these interviews to determine the dominant clusters of frames in the three locations of study.

\section{RESULTS}

The results indicate an erratic pattern regarding the accommodation and negotiation of intergroup relations in the period leading to the 2007-08 conflicts which were dependent on the stage at which the violence unfolded. Prior to active violence, intergroup relations were negotiated along past historical contingencies. During the active violence, the narratives of cross-victimisation and 
group survival appeared to be particularly salient. Following the period of active violence, the negotiation of intergroup relations took the form of civic ideals cutting across group allegiances.

\section{Pre-conflict Phase}

Considering the overall attitude towards the elections, the interviews suggest that the negotiation of intergroup relations centred on past historical contingencies. Most of these were linked to the colonial legacy that had led to the disintegration of local groups in an effort to create administrative boundaries, without paying attention to traditional bonds that held the groups together. In concrete terms the interviews revealed that land ownership, political representation, and group economic emancipation were key markers of intergroup relations, depending on how they were negotiated and disseminated to radio listeners.

For instance, the thorny issue of resettlement schemes following Kenya's independence from Britain in 1963 was emphasised by Kikuyu and Kalenjin radio stations to characterise intergroup relationships prior to the elections. At the core of these characterisations were the Majimbo (Swahili for devolutionism or regionalism) constitutional debates, salient in both Nyeri and Eldoret. While the interview with Kikuyu-language radio listeners emphasised the narratives of eviction as being the most dominant angle of news coverage, Kalenjin radio listeners pointed out that narratives of invasion (by the supposed Kikuyu 'foreign settlers') were accentuated. Luo-language radio listeners, on the other hand, indicated that intergroup relations were essentialised as a problem of political representation and the alleged betrayal by the Kibaki government following its election in 2002. This is how one of the respondents from Kisumu summarised these discussions:

... There was a sense of betrayal from the Kikuyu once Kibaki became the president in 2002. When Odinga campaigned so hard for him in 2002, Kikuyu and Luos were best friends. Once they [Kikuyu] got what they wanted, they decided to turn their backs from the very people who voted for them and disregarded the reforms that Odinga and other politicians campaigned for... . It was normal for the Luo voters to be reminded about what had happened in 2002 so that they are not fooled again.

(interview with a Luo radio listener, Kisumu, July 10, 2010).

Despite the differences in framing, Luo and Kalenjin radio listeners indicated that the narratives adopted by their respective radio stations demonised the Kibaki- 
led Party of National Unity (PNU). This strengthened the perception that the Kikuyu were the primary beneficiaries of the Kibaki government, and that it was necessary to fight for equity between groups. On the other hand, the interviews indicate that stations broadcasting in the Kikuyu language may have portrayed the Odinga-led Orange Democratic Movement (ODM) as an ethnically-minded party, and that its party leader could not be trusted with the country's leadership, presumably because of his dictator-like tendencies.

While the pre-conflict stage was characterised by dispersed frames with respect to electoral stakes, there were varying explanations of intergroup polarisation in the period leading to the 2007-08 election violence. Table 1 below indicates the dominant frames adopted by vernacular radio prior to the 2007-08 election violence.

Table 1: Dominant frames prior to active violence

\begin{tabular}{|l|c|c|c|}
\hline \multirow{2}{*}{ Framing category } & \multicolumn{3}{|c|}{$\begin{array}{c}\text { Dominant frames relating to intergroup polarisation } \\
\text { prior to the 2007-08 violence }\end{array}$} \\
\cline { 2 - 4 } & $\begin{array}{c}\text { Kisumu } \\
(\mathbf{n = 1 5 )}\end{array}$ & $\begin{array}{c}\text { Eldoret } \\
(\mathbf{n = 1 5 )}\end{array}$ & $\begin{array}{c}\text { Nyeri } \\
(\mathbf{n = 1 5})\end{array}$ \\
\hline Ethno-regional marginalisation & 13 & 9 & 6 \\
\hline Unfair land ownership & 10 & 15 & 5 \\
\hline Land ressettlement scores & 7 & 6 & 15 \\
\hline Dissent over a Luo presidency & 14 & 10 & 2 \\
\hline $\begin{array}{l}\text { Dissent over Kikuyu economic } \\
\text { successes }\end{array}$ & 3 & 5 & 13 \\
\hline
\end{tabular}

\section{Dominant frames during active violence}

Active violence was sparked by the announcement of presidential results giving outgoing president Kibaki a second term. During this period interviews showed that vernacular radio may have shifted its narratives from historically-situated grievances to a discourse of intergroup cross-victimisation and finger-pointing. Here, vernacular radio seemed to have strengthened the perception that certain groups were victims of hate, mistreatment, unfairness and political opportunism, which may have reinforced sentiments of attack, counter-attack, and self-defence strategies.

In concrete terms, active violence frames emanating from Kisumu and Eldoret negatively represented the Kikuyu, often linking them to the incumbent government believed to have stolen the elections. The heavy deployment of the police force in Kisumu and Eldoret was presented as the government's move to 
contain dissent from the Luo and Kalenjin groups, initially perceived as ODM's core supporters. In the process, vote-rigging, intolerance and government oppression seemed to be the main reasons provided as justification for election violence. One respondent in Eldoret had this to say about the cause of violence against PNU affiliates:

All the opinion polls gave Raila a strong lead over Kibaki, even during the actual tallying of the votes. A day before the official results, there was confusion all over, with contradictory messages coming from different journalists. At one point, we hear that Raila had been declared the winner, the next minute we hear that it is actually Kibaki who took it. This is what sparked anger and violence against the PNU party and their Kikuyu members. Everyone went to vote in peace, and they started playing around with people's will.... You don't expect us to keep quiet and let go our hard-earned victory. It is like stepping on a snake expecting it not to bite back.

(interview with a Kalenjin radio listener, Eldoret, August 7, 2010)

Kikuyu radio listeners, on the other hand, reported that most Kikuyu-language radio stations discredited such claims and emphasised the alleged planned attack on the Kikuyu communities by the Luo and Kalenjin groups. According to the interviews, self-defence and the need for ethnic survival may have been the outcome of these contested narratives, which may explain why discussions around Mungiki gangs also became prevalent (see Rasmussen 2010, pp. 301-319).

Although vote-rigging was also a central feature of Kikuyu language radio programmes, these claims were mainly framed in a manner that represented the Kikuyu as the primary targets of planned attacks, and that vote-rigging was used by the Luo and Kalenjin sponsors of violence to consolidate support for their planned attacks. The interviews pointed to the possibility of some politicians using vernacular radio to instil sentiments of separation rather than intergroup cohesion. As one respondent from Nyeri reported:

Some of these radios [vernacular] are mouthpieces for local politicians who used them to spread hate while advancing their personal interests .... Many Kikuyus were targeted and killed for political reasons, and some [radios] openly called for the eviction of our communities yet these people have lived there [Rift Valley] for decades. Where do they expect them to go? When you are attacked you have to defend yourself. I don't see the problem with the radios telling our people 
to watch out for the attacks. Whether Mungiki was involved in the attacks or not, the point is, these were planned attacks against the Kikuyus, and we had the right to protect.

(interview with a Kikuyu radio listener, Nyeri, September 6, 2010)

Vernacular radio frames during the period of active violence suggested that other groups were either untrustworthy, hateful, vengeful or intolerant. The discourse of power struggles has become the core frame used by most of the radio stations to characterise intergroup relations. Violence was thus justified in terms of selfdefence and group survival. Table 2 displays the main categories of frames that emerged when target radio listeners were asked to describe the reasons provided for the shift from electoral dispute to inter-ethnic violence.

Table 2: Dominant frames during the active violence stage

\begin{tabular}{|l|c|c|c|}
\hline \multirow{2}{*}{ Framing category } & \multicolumn{3}{|c|}{$\begin{array}{c}\text { Dominant frames relating to intergroup } \\
\text { violence in 2007/08 }\end{array}$} \\
\cline { 2 - 4 } & $\begin{array}{c}\text { Kisumu } \\
(\mathbf{n = 1 5 )}\end{array}$ & $\begin{array}{c}\text { Eldoret } \\
(\mathbf{n = 1 5 )}\end{array}$ & $\begin{array}{c}\text { Nyeri } \\
\text { (n=15) }\end{array}$ \\
\hline Vote-rigging & 15 & 13 & 10 \\
\hline Planned attacks & 3 & 2 & 15 \\
\hline Government mischief & 14 & 11 & 4 \\
\hline Land and territorial insecurity & 6 & 15 & 14 \\
\hline Power struggles and political opportunism & 15 & 15 & 15 \\
\hline
\end{tabular}

\section{Dominant Frames after Active Violence}

Official figures provided by the independent inquiry commission, commonly known as the Waki Commission, indicated that violence claimed the lives of 1100 people and displaced more than 700000 others. Subsequently, target radio listeners reported that vernacular radio changed its narratives. This time peace negotiations led by Kofi Annan and the urgency to reunite ethnic factions have been the message endorsed by several vernacular radio stations. Rather than focusing on historically-grounded grievances and cross-victimisation, radio programmes emphasised peace talks underway between Kibaki and Odinga, the two main rival political party leaders. Instead of emphasising disparate ethnic interests, these programmes strengthened the perception of collective or communal interests that cut across intergroup allegiances. Intergroup relations were now negotiated in terms of civic ideals rather than the perceived gains and/ or losses of individual groups. 
The interviews also revealed that various radio stations heightened the perception of a joint nation-building process, often reminding audiences of their collective pride in national achievements within the international arena such as tourism and world marathons. Such elements bring a sense of collective pride and unity. Post conflict, i.e. after the stage of active violence, power-sharing, nation-building, democratic governance and intergroup reconciliation became key angles of news analysis. These all reinforced the notion of collective ideals, while at the same time, consoling the victims of election violence. For instance, a respondent from Nyeri stated:

[...] The radios were very important because people were calling to console one another and offer their support to those who were displaced from their homes in various parts of the Rift Valley. Although many people had lost their lives at this point, people came to realise that violence was not the best way to resolve political differences. The innocent are always the ones who have to pay a higher.

(interview with a Kikuyu radio listener, Nyeri, September 10, 2010)

In concrete terms, vernacular radio stations shifted their narratives from a discourse indicating the association of individual groups with specific political parties, to one emphasising the power-sharing deal advocated by Kofi Annan and his mediation team. This reinforced the perception that key political leaders were willing to put aside their differences in order to end the violence and political stalemate. Instead of focusing on individual group solutions to the violence and perceived flawed electoral process, collective solutions were encouraged. These included the need for democratic reforms, with a constitutional amendment regarded as the main solution to longstanding political and historically-situated grievances between groups.

Further, these radio stations emphasised youth involvement in active politics, thus moving post-electoral analysis away from finger-pointing to policy-based issues. For instance, a respondent in Eldoret noted that, 'although it is true that local [vernacular] radios communicated separation in the past, we should also recognise their efforts in bringing the communities together and talking about issues that had caused the conflict such as youth unemployment' (interview with a Kalenjin radio listener, Eldoret, August 24, 2010). A similar reaction came from another Kisumu respondent who pointed out that 'the radios [vernacular] preached peace by inviting church leaders on their talk shows rather than politicians who had personal agendas' (interview with a Luo radio listener, Kisumu, July 21, 2010). Similarly, an interviewee from Nyeri observed that 'gospel songs dominated the 
airwaves instead of politically-driven songs that caused tension between different ethnic groups just before the elections' (interview with a Kikuyu radio listener, Nyeri, September 6, 2010).

According to the interviews, several radios refrained from using provocative songs as interlude or signature tunes, as had been the case prior to and during the period of active violence. Instead, religious and Swahili language national songs dominated the airwaves indicating the power of song in shifting attitudes in both violent situations or in search of peace. Table 3 shows the dominant frames used to accommodate intergroup relations after the active violence:

Table 3: Dominant frames after the active violence stage

\begin{tabular}{|l|c|c|c|}
\hline \multirow{2}{*}{ Framing category } & \multicolumn{3}{|c|}{ Dominant frames following the active violence stage } \\
\cline { 2 - 4 } & $\begin{array}{c}\text { Kisumu } \\
(\mathbf{n}=\mathbf{1 5})\end{array}$ & $\begin{array}{c}\text { Eldoret } \\
(\mathbf{n = 1 5 )}\end{array}$ & $\begin{array}{c}\text { Nyeri } \\
(\mathbf{n}=\mathbf{1 5})\end{array}$ \\
\hline Power sharing & 9 & 13 & 10 \\
\hline Youth engagement & 14 & 12 & 13 \\
\hline Intergroup reconciliation & 12 & 10 & 14 \\
\hline Nation building & 13 & 11 & 13 \\
\hline Democratic governance & 14 & 13 & 14 \\
\hline
\end{tabular}

Overall, the interviews revealed that the dominant frames following the active violence stage were fairly similar across different research sites. This points to two probabilities: first, it suggests that differences in framing are likely to change attitudes to the use of violence as a means to settle political differences. Second, the change in the framing process is also likely to shift the course or patterns of violence and intergroup relations over time and space. Frames emphasising collective ideals are more likely to strengthen collaborative attitudes, while those underscoring ethnic group loyalties reinforce divisive and rebellious attitudes. The next section discusses these shifts in detail.

\section{DISCUSSION}

The study examines how shifts in vernacular radio narratives influence intergroup relations in situations of electoral violence in Kenya, with particular emphasis on that of 2007-08. The study also explores how and why election-related violence often shifts from electoral discourse to embrace ethnicity. Overall, the findings suggest a slanted framing process at different stages when violence manifested itself, most of which hinged on historical contingencies, intergroup crossvictimisation and the notion of collective interest. 
Prior to the active violence stage, historical grievances served as key drivers of news content and, by extension, the incentive to instil a sense of displeasure with the way the then-outgoing government had handled these perceived grievances. This explains why land ownership debates, emphasised by the Kalenjin and Kikuyu radio stations, resonated well with vernacular radio listeners in Eldoret and Nyeri. As other studies have also shown, questions about land ownership and resettlement policies have been particularly acute in these regions (Lynch 2008; Klaus 2015). The perception that the Kikuyu group were the primary beneficiaries of unfair land occupancy and tenure systems transformed into attacks and counter-attacks between the perceived invaders and evictor. Luo radio stations, on the other hand, reinforced the perception that the Kikuyu group were particularly opposed to Raila Odinga's presidency and, by extension, the Luo group's perceived ascendance to political power. From the framing perspective, this shows that negatively framed messages, whether true or false, reinforce divisive attitudes amongst various groups. Similarly, these frames show how cultural proximity and/or particularities can be conveniently used to define intergroup boundaries in violent situations. These factors may explain the ethnic turn in violent electoral processes.

Regarding the stage of active violence, the findings indicate that every group appeared to be a victim of something, with violence being justified on the grounds that it ensures group survival and self-defence. In so doing, vernacular radio stations appeared to mobilise and incentivise specific group beliefs to achieve specific objectives. These include generating a sense of intergroup mistrust while demonising other groups as the reason for their perceived suffering or political neglect. Accordingly, the results indicate that Luo language radio programmes emphasised the notion that the Kikuyu group had transformed the state into a family business in which other groups had only subordinate roles in state machinery. This perception was backed by narratives of vote-rigging and government mischief, and claims that the outgoing government was using the police force to contain political dissent. On the other hand, Kikuyu language radio stations explained the violence in terms of planned attacks by ODM party sympathisers, and that the party leader Raila Odinga was unwilling to concede defeat. For their part, Kalenjin language radio stations identified unfair land ownership as the primary cause of bad blood between Kikuyu and Kalenjin. Active violence frames therefore served to maintain intergroup distrust, thereby strengthening rebellious attitudes between different groups.

Finally, the results of the study indicate that post-conflict frames emphasised collaborative efforts to contain the violence after the 2007-08 election in order to reinforce intergroup reconciliation. Vernacular radio stations seemed bound together by the belief that a civil war was in the making and also by the fear that 
several radio stations risked being shut down. They thus changed their narratives from divisive frames to a position supporting ongoing power-sharing negotiations, often highlighting the need to collaborate in joint political problem-solving. The realisation that the violence had claimed innocent lives may have also been at the heart of the shifting narratives. In essence, the change in the framing process encouraged collaborative attitudes between groups and underpinned the urgency for dialogue and political settlement between the two party affiliates.

The central overarching message, according to the findings, was the need for political reforms. These were seen as the first step towards a meaningful solution of problems of governance and the restoration of intergroup trust which had been significantly eroded by acts of violence. Figure 1 below represents potential changes in vernacular radio frames and related attitudinal shifts during the 200708 election violence:

\begin{tabular}{|c|c|c|}
\hline Pre-active violence & Active violence & Post-active violence \\
\hline $\begin{array}{l}\text { - Perceptual } \\
\text { differences based } \\
\text { on political, } \\
\text { economic, cultural, } \\
\text { territorial and media } \\
\text { representations } \\
\text { - Narratives of image } \\
\text { correction, whether self } \\
\text { or group } \\
\text { - Potential frame outcomes: } \\
\text { Intergroup distrust and } \\
\text { demonisation; divisive } \\
\text { attitudes; violence as a } \\
\text { potential solution }\end{array}$ & $\begin{array}{l}\text { - Conflicting } \\
\text { perceptions } \\
\text { of self/group } \\
\text { and cross- } \\
\text { victimisation } \\
\text { - Narratives of territorial } \\
\text { insecurity and perceived } \\
\text { risk of electoral loss/gain } \\
\text { - Potential frame } \\
\text { outcomes: Intergroup } \\
\text { attack and counter-attack } \\
\text { as a means to achieve } \\
\text { intended goals; rebellious } \\
\text { attitudes }\end{array}$ & $\begin{array}{l}\text { - Compromise } \\
\text { with respect to } \\
\text { the perceived } \\
\text { misrepresentation } \\
\text { of self/group } \\
\text { - Narratives of national } \\
\text { insecurity and the urgency } \\
\text { to reconcile electoral loss/ } \\
\text { gain perceptions } \\
\text { - Potential frame outcomes: } \\
\text { Intergroup attack and } \\
\text { counter-attack as a means } \\
\text { to achieve intended goals; } \\
\text { rebellious attitudes }\end{array}$ \\
\hline
\end{tabular}

\section{Figure 1: Shifts in vernacular radio frames and changes in intergroup attitudes during violence}

Although Figure 1 appears to suggest linearity in its frame sequence, it should be noted that post-conflict discourse can fall back to pre-conflict or active violence frames depending on how the perceived differences are negotiated across groups, time, and space. That is, depending on frame categories, violence is more likely to escalate or de-escalate as people's perception of electoral stakes shifts. This includes the outcome of violence such as the number of victims, damage to property and increased insecurity. Even in the de-escalation process, if the narratives of compromise and reconciliation no longer reflect the perceived 
collective interests, the framing may relapse into that of pre-conflict ${ }^{1}$. As a result, another violent incident might take shape because of these latent forces, and possibly transform into lasting conflict. The dilemma in the de-escalation process may be twofold. First, radio hosts may be driven by the conviction that encouraging diversity of views (e.g. through phone-in programmes and music on air) strengthens democratic participation in matters relating to election violence. This rests on the assumption that the inclusive voice is key to conflict resolution. On the other hand, encouraging diverse positions on air requires a delicate balance between positions and intended outcomes, especially when certain voices advocate justified violence against the perceived outsiders. While the former poses the question of credibility, integrity and autonomy with regard to vernacular radio frames, the latter is concerned with issues of sensationalism, objectivity and ethnic tolerance.

The findings also show that the narratives of cross-victimisation are more prevalent during times of conflict. This suggests that intergroup violence is likely to escalate whenever vernacular radio frames encourage their listeners to adopt defensive strategies such as attacks and counter-attacks instead of reconciliatory practices. Violence in this regard can also be used as a measure of power and/or weakness, thereby redefining intergroup relational boundaries. In the words of Jean-Jacques Rousseau (2008, p. 16):

the strongest is never strong enough to be always the master, unless he transforms strength into right, and obedience into duty. Hence the right of the strongest, which, though to all seeming meant ironically, is really laid down as a fundamental principle.

If it is true that violence can be framed as a means by which people test their power and redefine their relational boundaries, radio frames are therefore key in determining whether ongoing violence transforms into peaceful negotiations for long-term stability or escalates into more violence and a potential civil war.

In the aftermath of conflict, vernacular radio frames adopt narratives that cut across perceived group or party loyalties. Unlike the phases before and during active violence, post-conflict frames tend to repair broken relational bonds by strengthening collaborative attitudes. Radio listeners (understood here as potential participants in violence) may resort to short- or long-term solutions through compromise or by adopting what Covey (2011) calls the principle of

1 Violence in this regard can take other forms such as strong or unpleasant emotions/feelings directed toward another group. This may transcend the conventional understanding of violence as a physical harm. 
synergy ${ }^{2}$ to transcend acts of violence in the long term. For instance, perceived national interests, often defined along the lines of citizenship or national selfdetermination, were specifically emphasised following the active conflict phase. Narratives underpinning individual political interests were minimal.

Although post active violence narratives may not necessarily resolve deepseated feelings about the causes and consequences of electoral violence, they may alter the direction and intensity of violence. In this way, violence may either regain its latent nature (understood here as strong or unpleasant emotions/feelings directed toward another group) or encourage long-term solutions where both parties feel satisfied with the decisions reached. In other words, the elasticity of vernacular radio frames varies depending on the stage at which the violence manifests itself. Therefore, the shifts from electoral discourse to ethnicity are likely to be the result of the framing process and the degree of resonance of the proposed frames with regard to perceived fears, insecurities, and intended outcomes.

Ultimately, elasticity in the framing process can be understood in terms of fragmented and concerted framing. Differentiated framing may underscore a form of media/radio narrative whereby group differences are negotiated in terms of competition likely to generate intergroup polarisation. That is, one group or a coalition of groups is perceived as the primary beneficiary of an election outcome. This kind of framing is more likely to be prevalent before active violence and in its early stages, when claims of ethnic essentialism become the defining characteristics of nationhood or intergroup relations. Ethnicity, in this regard, is defined in terms of blood (consanguineal) kinship and common ancestry. Differentiated framing may reinforce feelings of exclusivity and/or competitive attitudes, giving less room for constructive dialogue or compromise between the perceived warring groups. Although differentiated framing may characterise intergroup tensions and subsequent intergroup violence, intra-group tensions may also stem from this kind of framing, especially when members of the same group are faced with intense competition from within.

In contrast, concerted framing describes radio and media narratives negotiated in terms of values that cut across intergroup interests, thereby reinforcing a sense of collective goals such as intergroup peace. Here, vernacular radio stations may choose to embrace narratives that call for intergroup reconciliation and cohesion, public safety, political integrity, and the rule of law. While there is no certainty that such frames will change the course of violence, they tend to instil collaborative

2 Covey defines the principle of synergy as 'what happens when one plus one equals ten or a hundred or even a thousand [because] it's the mighty result when two or more respectful human beings determine together to go beyond their preconceived ideas to meet a great challenge. It's all about the passion, the energy, the ingenuity, the excitement of creating a new reality that is far much better than the old reality' (p. 12). 
attitudes among groups and encourage the search for a common solution to acts of violence. Concerted framing is more likely to emerge in the late stages and aftermath of a prolonged phase of active violence. Here, vernacular radio narratives could potentially shift from emphasising intergroup competition to underpinning values and practices shared by the majority of the groups, such as the subtle emotional appeal of religious songs. Such practices may temporarily halt the violence while groups negotiate various options for peace. Ethnicity, in this regard, is not articulated as a sine qua non of blood kinship or common descent but instead are associated citizenship and national self-determination. Overall, concerted framing is likely to reinforce inclusive and collaborative attitudes that address intergroup differences through dialogue, compromise and synergy.

\section{CONCLUSION}

This article examined how vernacular radio narratives influence patterns of election violence, using the 2007-08 election crisis in Kenya as a case study and framing as an analytical framework. It goes beyond normative approaches that underpin ethno-political categorisation as the primary cause of electoral violence in multi-ethnic societies to examine the role of radio frames from the perspective of radio listeners in Kisumu, Eldoret and Nyeri. It showed that ethnic groups may profoundly differ in the ways they perceive each other and how they make sense of election violence based on the narratives circulated and their interpretations. The symbolic power of language and cultural allegiances is found to be a key driver of vernacular radio frames, as they infiltrate the inner feelings of various ethnolinguistic groups when giving meaning to different occurrences. Most importantly, vernacular radio frames can either be differentiated or concerted, depending on the levels at which the violence manifests itself, prompting divergent attitudes towards intergroup relations. Overall, the findings of this study offer insights into understanding how, why and when vernacular radio may be used to influence perceived electoral stakes and related violence.

\section{Acknowledgement}

An earlier version of this paper was presented at the 2012 Annual International Conference on Journalism \& Mass Communication and at the Annual Congress of the ACFAS (Association francophone pour le savoir) in 2013. 


\section{----- REFERENCES}

Altheide, DL 2009, 'Media and Mediated Evidence', Cultural Studies-Critical Methodologies, vol. 9 no. 1, pp. 14-22.

Avraham, E \& First, A 2010, 'Combining the representation approach with the framing concept: Television news coverage of the Arab population in Israel during conflict', Journalism, vol. 11, no. 4, pp. 481-499.

Barker, D \& Knight, K 2000, 'Political Talk Radio and Public Opinion' European Journal of Women's Studies, vol. 64, no. 2, pp. 149-70.

Bronstein, C 2005, 'Representing the Third Wave: Mainstream Print Media Framing of a New Feminist Movement', Journalism \& Mass Communication Quarterly vol. 82, no. 4, pp. 783-803.

Brown, S 2011, 'Lessons Learned and Forgotten: The International Community and Electoral Conflict Management in Kenya', In D Gillies (ed.), Elections in Dangerous Places: Democracy and the Paradoxes of Peacebuilding, pp. 127-43, McGill-Queen's University Press, Montreal.

Chepkoech, A 2015, 'How the ICC charges turned my world upside down', Daily Nation 5 July. Available at https://www.nation.co.ke/lifestyle/lifestyle/joshua-sang-ICC-charges-turned-my-world-upside-down/12142775408-15gkxpf/index.html [accessed, 2019].

Cohen, AP 1994, Self-Consciousness: An alternative anthropology of identity, Routledge, London.

Cottrell, J \& Ghai, Y 2007, 'Constitution Making and Democratization in Kenya (2000-2005)', Democratization, vol. 14, no. 1, pp. 1-25.

Covey, S 2011, 'The Third Alternative: Solving World's Most Difficult Problems', Free Press, New York.

D'Angelo, P 2011, 'Studying Framing in Political Communication with an Integrative Approach', American Behavioral Scientist, vol. 56, no. 3, pp. 353364.

El-Nawawy, M \& Powers, S 2010, 'Al-Jazeera English: A conciliatory medium in a conflict-driven environment?', Global Media and Communication, vol. 6, 1, pp. 61-84.

Entman, RM 1993, 'Framing: Toward clarification of a fractured paradigm', Journal of Communication, vol. 43, 4, pp. 51-8.

Entman, RM 2010, 'Media framing biases and political power: Explaining slant in news of Campaign 2008', Journalism, vol. 11, 4, pp. 389-408.

Frère, M-S 2009, 'After the hate media: regulation in the DRC, Burundi and Rwanda', Global Media and Communication, vol. 5, 3, pp. 327-352.

Goffman, E 1974, 'Frame Analysis: An Essay on the Organization of Experience', Harvard University Press, Cambridge, MA. 
Gower, KK \& An, S-K 2009, 'How do the news media frame crises? A content analysis of crisis news coverage', Public Relations Review, vol. 35, pp. 107-112. Hammer, R \& Kellner, D (eds.) 2009. 'Media/Cultural studies: Critical approaches', Peter Lang Publishing Inc., New York.

Human Rights Watch 2009, 'Human Rights Watch world report', Human Rights Watch, New York.

Jamal, AI and Deane, M 2008, 'The 2007 general elections: the role of local language media', The International Journal of Press/Politics, vol. 13, no. 3, pp. 319-327.

Helander, E 2010, 'A critical view of the Kenyan media system through the perspective of the journalists', African Communication Research, vol. 3, no. 3, pp. 521-542.

Kaburahe, A 2004, 'La mémoire blessée', La Longue Vue, Brussels.

Kaufman, S \& Smith, J 1999, 'Framing and Reframing in Land Use Change Conflicts', Journal of Architectural and Planning Research, vol. 16, no. 2, pp. 164180.

Klaus, KD 2015, 'Claiming Land: Institutions, Narratives, and Political Violence in Kenya', PhD diss., University of Wisconsin-Madison.

Kolmer, C \& Semetko, HA 2009, 'Framing the Iraq War: Perspectives from American, U.K., Czech, German, South African, and Al-Jazeera News', American Behavioral Scientist, vol. 52, no. 5, pp. 643-656.

Lecheler, S \& de Vreese, CH 2012, 'News Framing and Public Opinion: A Mediation Analysis of Framing Effects on Political Attitudes', Journalism \& Mass Communication Quarterly, vol. 89, no. 2, pp. 185-204.

Lekgoathi, SP 2012, 'Ethnic Separatism or Cultural Preservation? Ndebele Radio under Apartheid, 1983-1994', South African Historical Journal, vol. 64, no. 1, pp. 59-80.

Lohner, J, Banjac, S, \& Neverla, I 2016, 'Mapping structural conditions of journalism in Kenya', Media Conflict and Democratization (Working Paper), University of Leeds.

Lynch, G 2008, 'Courting the Kalenjin: Failure of Dynasticism and the Strength of the ODM Wave in Kenya's Rift Valley Province', African Affairs, vol. 107, no. 429 , pp. 541-568.

Matthes, J 2012, 'Framing politics: An integrative approach', American Behavioral Scientist, vol. 56, no. 3, pp. 247-259.

Neyazi, TA 2010, 'Cultural imperialism or vernacular modernity? Hindi newspapers in a globalizing India', Media Culture Society, vol. 32, no. 6, pp. 907924.

Odhiambo, LO 2002, 'The Media Environment in Kenya Since 1990', African Studies, vol. 61, no. 2, pp. 295-318. 
Ogola, G 2011 'The political economy of the media in Kenya: from Kenyatta's Nation-building Press to Kibaki's local-Language FM radio', Africa Today vol. 57, 3, pp. 77-95.

Osaghae, EE 1999, 'Conflict Research in Africa', International Journal of World Peace, vol. 16, pp. 53-72.

Rasmussen, J 2010, 'Mungiki as youth movement: Revolution, gender and generational politics in Nairobi, Kenya', Young/Nordic Journal of Youth Research, vol. 18, no. 3, pp. 301-319.

Republic of Kenya 2008, Commission of Inquiry into Post-Election Violence (The Waki Report), Government Printer, Nairobi.

Rice, X 2008, 'We told them to come out of the church, but they locked the door ... So we burned them', The Guardian, accessed November 2010, https://www. theguardian.com/world/2008/jan/02/kenya1

Rousseau, J-J 2008, The social contract, tr GDH Cole, Cosimo Classics, New York. Royal Media Services 2019 https://www.royalmedia.co.ke [Accessed May 20, 2019]. Schweitzer, ME, DeChurch, LA \& Gibson, DE 2005, 'Conflict frames and the use of deception: are competitive negotiations less ethical?', Journal of applied psychology, vol. 35, no. 10, pp. 2123-214.

Shah, DV, McLeod, DM, Gotlieb, MR \& Lee, N 2009, 'Framing and agenda-setting'. In R Nabi \& MB Oliver (Eds.), Handbook of media processes and effects (pp. 8398), Sage, Los Angeles.

Simons, G 2008, 'Mass media and the battle for public opinion in the global war on terror: violence and legitimacy in Iraq', Perceptions, Spring-Summer 2008. Somerville, K 2009, ‘British media coverage of the post-election violence in Kenya, 2007-08', Journal of Eastern African Studies, vol. 3, no. 3, pp. 526-542.

Tewksbury, D \& Scheufele, DA 2009, 'News framing theory and research', In J Bryant \& MB Oliver (Eds.), Media effects: Advances in theory and research (3rd ed., pp. 17-33), Routledge, New York.

Thomson, A 2007, 'Media and the Rwanda genocide', Pluto Press, London.

Throup, DW \& Hornsby, C 1998, 'Multi-Party Politics in Kenya: The Kenyatta and Moi States and the Triumph of the System in the 1992 Elections', James Currey, Oxford.

Tomaselli, K \& Muller, J 2001, 'Narrating the Crisis: Hegemony and the South African Press', Critical Arts, vol. 6, no. 1, pp. 110-112,

Wanyande, P 1995, 'Mass Media-State Relations in Post-Colonial Kenya', African Media Review, vol. 9, no. 3, pp. 54-75.

Waweru, T 2018, 'Editors Guild condemns threats to media houses by Jubilee Government', Standard 30 January. Available at https://www.standardmedia.co.ke/article/2001267731/editors-guild-condemns-threats-to-mediahouses-by-jubilee-government [Accessed June 7, 2019]. 
Weaver, DH 2007, 'Thoughts on agenda setting, framing, and priming', Journal of Communication, vol. 57, no. 1, pp. 142-147.

Wolff, S 2004, 'Disputed territories: The transnational dynamics of ethnic conflict settlements', Berghan Books, New York.

Zuckerman, E 2009, 'Citizen media and the Kenyan electoral crisis', In S Allan \& E Thorsen (eds.), Citizen Journalism: Global Perspectives, Peter Lang, New York. 


\title{
CRIMES INVOLVING DISHONESTY OR MORAL TURPITUDE IN MALAWI'S ELECTIONS
}

\section{Gift Dorothy Makanje}

Gift Dorothy Makanje is Head of the Department of Foundational Law, University of Malawi, Zomba

\begin{abstract}
The Constitution of the Republic of Malawi disqualifies any person for election as president, vice president or member of parliament who has, within the last seven years, been convicted by a competent court of a crime involving dishonesty or moral turpitude. The Local Government Elections Act also disqualifies such a person from being elected as a councillor on similar grounds. In addition, once elected, these office holders can lose their seats on similar grounds. The question becomes, what are crimes involving dishonesty or moral turpitude? Worldwide, courts have struggled to define this amorphous concept. In Malawi, a few cases have been heard in both the High Court and the Supreme Court of Appeal to determine whether the offences in issue were crimes involving dishonesty or moral turpitude. The courts have labelled some offences as involving dishonesty or moral turpitude, in other instances have rejected this label and in yet others have avoided expressing an opinion one way or another. What is clear is that these words remain vague but will keep coming up in the courts for determination in relation to various offences. This paper is of the view that this disqualification is an unlawful limitation of various political rights guaranteed under section 40 of the Constitution. While exploring different approaches to clarify the phrase moral turpitude, it is ultimately recommended to simply scrap this disqualification from the law and to empower the electorate to freely choose whoever they want.
\end{abstract}

Keywords: crimes, moral turpitude, dishonesty, Malawi, elections, politics

\section{INTRODUCTION}

The phrase 'moral turpitude' in relations to elections appears in four provisions in Malawian law, three of which are in the Constitution of the Republic. It first 
appeared in the 1994 Constitution in section 80(7)(c) which stipulates that a person shall not be eligible for nomination as a candidate for election as president or first vice president or for appointment as first vice president or second vice president if that person has, within the last seven years, been convicted by a competent court of a crime involving dishonesty or moral turpitude. Nomination and election for members of parliament are similarly excluded by section 51(2)(c), section 94(3)(c) covers disqualification for appointment as a minister or deputy minister ${ }^{1}$, and section 27(2(c) of the Local Government Elections Act (LGE) disqualifies a person from being elected as a councillor on the same grounds.

In addition, after having been elected these office holders may also lose their seats if convicted on these grounds. Yet neither the Constitution nor the LGE define crimes involving dishonesty or moral turpitude or stipulate a clear method that judges can use to determine these crimes. Considering that being convicted of a crime involving dishonesty or moral turpitude carries such grave consequences for public office, it becomes incumbent to discuss the meaning of this phrase and its efficacy. It appears that the phrase is so amorphous that courts worldwide struggle to define it. Yet the question of which crimes involve moral turpitude so as to make someone ineligible for election or appointment to certain offices will keep coming up in our courts. Further, while there appears to be not much disagreement regarding crimes involving dishonesty, the bone of contention is 'crimes involving moral turpitude'. For this reason, crimes involving moral turpitude are the focal point here.

So, what exactly are crimes involving moral turpitude? What is the history behind this phrase in our law? How have Malawian courts interpreted this phrase? Is a conviction for a crime involving moral turpitude a legitimate disqualification from election to the offices of councillor, member of parliament or even the presidency? This paper seeks to answer these questions and more.

There are very few Malawian cases on this issue and even those few seem inconclusive on many relevant questions regarding crimes involving moral turpitude, leaving numerous questions unanswered. The meaning of which crimes involve sufficient moral turpitude as to make someone ineligible for election or appointment to certain offices is as nebulous as ever. This paper will critically analyse the few Malawian cases on this point to highlight how our courts have addressed the issue. It will also examine foreign jurisprudence and highlight various approaches to interpreting this phrase. The paper is of the view that the use of this notoriously amorphous concept to bar people from election or appointment to such high office does not resonate well with the constitutional

1 This paper will however focus on the elected offices, though the discussion is relevant even for ministerial appointments. 
right to stand for election for any elective office, as well as the right of constituents to vote for someone of their choice. Removal of this disqualification for these offices is therefore recommended.

\section{WHAT ARE CRIMES INVOLVING MORAL TURPITUDE?}

The phrase 'crimes involving moral turpitude' has been a popular subject of judicial interpretation in the United States of America (US) more than any other country (Simon-Kerr 2012, p. 1001). The US has a rich jurisprudence on crimes involving moral turpitude in relation to various purposes but mostly in immigration. In contrast, there is a dearth of jurisprudence on this point from both other African countries and the United Kingdom. Key local cases on this point rely on cases from the US and for this reason this paper will make extensive use of US jurisprudence.

The phrase 'crimes involving moral turpitude' as used in the above provisions does not create a new criminal offence nor does it declare certain conduct to be criminal. All it does is attach the label of moral turpitude to a particular crime following which the consequences stipulated in law may be visited upon the person concerned. But which crimes fit the label? As the Constitution and the LGE Act have neither defined the phrase nor indicated the list of crimes includable in this phrase, it is now left to the courts to determine various crimes that can be said to include moral turpitude. Unfortunately, this is no easy task because reference must be made to fluid moral standards prevailing in a not-so-homogeneous society and a decision made whether a particular offence can be said to be immoral. For this reason, the phrase has never had a universally accepted single definition.

Courts grappling to attach meaning to this phrase have indicated that the phrase is: an elusive concept (Luyimbazi \& Kasirye V Bazigatirawo \& the Electoral Commission of Uganda, HCT-00-CV-EP-0044 of 2011); a nebulous concept (Matter of Perez Contreras, 20 I \& N Dec 615, BIA 1992); notoriously plastic (Ali v Mukasey $521 \mathrm{~F} 3 \mathrm{~d}$ 737, $7^{\text {th }}$ Cir 2008); an amorphous morass (Partyka V AG of US $417 \mathrm{~F} .3 \mathrm{~d}$ 408, $3^{\text {rd }}$ Cir 2005); an invitation to judicial chaos (People v Castro 696 P. 2d 111, Cal.1985) and even an undefined and undefinable standard (Jordan V De George 71 S. Ct 703, 1951)2.

The case of Tembo and Kainja V Attorney General [2002-2003] MLR 229 HC seems to be the only Malawian case where the court adequately considered the meaning of crimes involving moral turpitude in relation to elections and the holding of political office in Malawi. The court was invited to determine whether contempt of court is a crime involving moral turpitude. In answering the question

2 Per Justice Jackson, dissenting. 
of what crimes involving moral turpitude are, the court relied on Black's Law Dictionary definition of the phrase and also made reference to some US judgments which also relied on the same definition. This seems to be the most commonly used definition by courts, defining moral turpitude as:

act of baseness, vileness, or the depravity in private and social duties which man owes to fellow man or to society in general, contrary to accepted and customary rule of right and duty between man and man. Act or behavior that gravely violates moral sentiment or accepted moral standards of community and is a morally culpable quality held to be present in some criminal offences as distinguished from others. The quality of a crime involving grave infringement of the moral sentiments of the community as opposed to statutory mala prohibita.

The court further adopted a definition of the phrase from North American decisions which define crimes involving moral turpitude as 'conduct... contrary to the accepted rules of morality and duties owed between persons or to society in general... an act which is per se morally reprehensible and intrinsically wrong'.

Black's Law Dictionary offers by far the most popular definition of crimes involving moral turpitude as adopted by courts. While there is a dearth of jurisprudence on the issue from other African countries, the Ugandan court also adopted this definition. Nevertheless, this definition does not provide a clear and precise meaning of what crimes involving moral turpitude are or which specific crimes are includable in the phrase. It assumes consensus on public morality and the ability of judges to identify such. Yet, what are the accepted and customary rules of right and duty between one person and another in Malawi and which crimes violate such? What are the moral sentiments or accepted moral standards of the Malawian community? Which Malawian community? Is the Malawian community homogenous with uniform moral sentiments and standards? Who decides those standards? Which conduct is morally reprehensible and to whom? Is the judge best placed to determine this? How does the judge gauge contemporary moral standards prevailing in Malawi? These and many more questions remain unanswered and the phrase, crimes involving moral turpitude, remains vague. Even the courts' definitions and meanings attached to the phrase seem ambiguous.

All this leads to uneven application as judges rely on their own biases or on precedent decisions where other judges have also relied on their own biases to decide which offences are morally reprehensible (Genovese 2018). For instance, some judges have treated false statements as crimes involving moral turpitude while others are of the opposite view (Ghani V Holder 557 F. 3d 836, $7^{\text {th }}$ Cir. 2009 \& Hirsch V Immigration \& Naturalisation Serv 308 F. 2d 562, $9^{\text {th }}$ Cir 1962). In some 
cases judges have held that money-laundering crimes are those involving moral turpitude while others have held the opposite view (Matter of Tejano, 24 I \&BN Dec 97, BIA 2007 \& Goldeshtein V I.N.S. 8 3d 645, 9 $9^{\text {th }}$ Cir 1993). By 1951 the US had over 50 cases in various courts which had applied the phrase at issue but without consistency, each case depending on the moral reactions of particular judges to particular offences (Jordan V De George 71 S. Ct 703, 1951). All this evidences the phrase's amorphous nature and its potential for arbitrary enforcement.

The final determining factor as to what meaning is attached to the phrase and which particular crimes are captured by it is the judge's own moral sense. Presidential, parliamentary and local government candidates (and their constituents) with criminal convictions do not have definite notice of whether they are eligible for election or whether they can be removed. Their fate depends on the whims of judges and this may lead to arbitrary enforcement. The phrase crimes involving moral turpitude indeed seems to be an undefined and undefinable standard (ibid.).

\section{HISTORY OF CRIMES INVOLVING MORAL TURPITUDE IN MALAWI}

The moral turpitude standard does not have a long trajectory in Malawi. It dates back to the 1995 National Constitutional Conference on the Provisional Constitution. The inclusion of crimes involving moral turpitude as a disqualification for the presidency was one of the most controversial issues for the constitution committee to the National Assembly and was most debated when the committee discussed section 80 , section 7 (c). The focal point was on crimes involving moral turpitude with barely any discussion on the dishonesty aspect. A majority of the members considered that crimes involving moral turpitude should, for a limited time, remain a disqualification for the presidency. The most popular reason given was that people change and society must not condemn them forever, but forgive and offer them another chance. Political positioning seems to have motivated this reasoning as memories were fresh that the newly elected democratic president, Dr Bakili Muluzi, had managed to win Malawi's first-ever multiparty elections despite having been convicted of theft.

In the initial debate a few members indicated that the phrase be expanded to include all offences, not merely crimes involving dishonesty or moral turpitude, while others favoured retaining the section with no time limit. Only two members indicated that the section was not necessary and should be removed altogether, and one of these asked the key question of who decides what is morally right and morally wrong. In this initial debate only two members attempted to discuss why the section should be retained. The first member indicated that it should be retained because in other Commonwealth countries criminal convictions 
bar candidates. The second indicated that as criminal convictions can make a candidate ineligible even for a civil service appointment the same should apply to the president.

The focus of discussion in the initial debate was on whether the section should be retained with a time limit and for how long? Following this, the vote was on two issues, viz. whether section (7)(c) should be removed or retained, and whether it should be retained with a time limit. Members favoured retaining the section, but the key issues remained unsettled: whether the section should be retained with a seven-year limit, or longer/shorter. Suggestions ranged from seven years to ten and less, but these seem to have been random figures as they were not justified nor was there evidence of how long it takes for a convict to reform. The second issue was whether the section should be modified to extend the range of offences covered, and the discussion remained hotly contested. In this second debate there was again minimal discussion on crimes involving dishonesty, the focus being on crimes involving moral turpitude.

- In discussing the phrase 'crimes involving dishonesty or moral turpitude' some members were of the view that the term moral turpitude is ambiguous and that it is better to bar anyone convicted by any court of any crime. This was opposed on the basis that it would include even traffic offences. Instead, it was suggested that the section should only cover serious crimes such as treason, sedition, arson, rape and murder. However, treason and sedition are threats to democracy and not crimes involving dishonesty or moral turpitude. Views included that moral turpitude is a vague term that can include a wide range of issues and so it should be changed.

- Could and should moral turpitude could be defined.

- Moral turpitude does not cover traffic and political offences though one response was that knowingly driving without a licence could fall under this section.

- Finally, it was also suggested that it was best to penalise any conviction without the option of a fine as this would exclude minor offences.

When the issue was again put to the vote 140 members supported retaining the section with a seven-year limit; 107 were against the retention and in favour of removal, while two votes were invalid. The conference finally resolved that section $80(7)$ (c) was to be retained in its present form which is mirrored in section 51(2) (c), 94(3)(c) and the LGE Act. 
So contentious was the issue that even after voting members continued debating the provision, indicating their dissatisfaction. It was suggested that they should take a further vote on the outstanding issue of whether to modify or extend the range of offences covered by the section and whether to define moral turpitude. Finally, the conference resolved by consensus that drafting experts should consider the record of the conference with a view to the possible modification of the section by extending the range of offences.

From the conference proceedings it is clear that the term moral turpitude is so vague and ambiguous that even after protracted debates lawmakers could not decide their meaning, leaving the matter to drafting experts. That drafting experts failed to do so left judges to decide which crimes are more immoral than others, mirroring popular concerns about the amorphous nature of crimes involving moral turpitude. It is clear that lawmakers wanted the section to apply to serious offences only, but unfortunately they failed to reach a consensus on which specific serious offences involve moral turpitude.

\section{Judicial Interpretation of Crimes involving Moral Turpitude in Malawi}

Experience is the life of the law, according to Johnson V US 2015 US Court of Appeals, $8^{\text {th }}$ Cir. Malawi's experience in trying to derive meaning regarding crimes involving dishonesty or moral turpitude, is as follows:

The first opportunity for the judiciary to decide the meaning of a crime involving dishonesty and moral turpitude in relation to elections and the holding of political offices came in 2003. The High Court in the Tembo and Kainja case was called upon to decide whether contempt of court is a crime involving dishonesty or moral turpitude. In that case, Mr Gwanda Chakuamba obtained a court injunction restraining the plaintiffs from holding a convention for the Malawi Congress Party (MCP). Despite having full notice and knowledge of the injunction, the plaintiffs proceeded to hold the convention in defiance of the court order. On these grounds the plaintiffs were found guilty of contempt of court and were sentenced to a fine of K200,000 in default 12 months imprisonment. They paid the fine and there was no appeal against sentence or conviction. Acting on these facts, the National Assembly proceeded to declare their seats vacant under section 63(1)(e) of the Constitution.

The key question for the court was whether contempt of court was a crime involving dishonesty or moral turpitude conviction which rendered the accused subject to removal under section 63(1)(e). Having determined that contempt of court was a crime, the court began by stating that section 51(2)(c) of the Constitution applies to sitting members of parliament as far as their removal from their seats is concerned. This is by virtue of section 63(1)(e) which provides that the seat of 
a member of the National Assembly shall become vacant if any circumstances arise that, if a person were not already a member of parliament, would cause that member to be disqualified for election under the Constitution or any other Act of Parliament.

The court then indicated correctly, in our view, that section 51(2)(c) does not demand that the crime should involve both dishonesty and moral turpitude. It is clear from a reading of the section that either dishonesty or moral turpitude suffices. On whether contempt of court involves dishonesty, the court referred to Black's Law Dictionary which defines dishonesty as: 'a disposition to lie, cheat, deceive, or defraud; untrustworthiness; lack of integrity; lack of honesty, probity or integrity in principle, lack of fairness and straight forwardness and a disposition to defraud, deceive or betray'. The court indicated that dishonesty equals any of the meanings prescribed in that dictionary and thus proceeded to hold that contempt of court was an offence involving dishonesty.

Regarding whether contempt of court was a crime involving moral turpitude, the court again referred to the definition in Black's Law Dictionary quoted above, and also adopted the definition of the phrase as discussed in US cases (see above).

Again referring to American jurisprudence, the court indicated that in deciding whether a crime involves moral turpitude, the focus should be on the nature of the crime and not the circumstances in which it was committed. This popular approach to dealing with crimes involving moral turpitude in the US is known as the categorical approach. This approach has also been used in Uganda (Bazigatirawo case, HCT-00-CV-EP-0044 of 2011). Its viability to Malawi is discussed below.

The court reiterates the same definition of crimes involving moral turpitude that judges have applied in almost all cases in the US. However, the definition as highlighted above is inadequate and unclear. For instance, what offences are regarded as vile, base, and/or depraved from a Malawian moral perspective? Or morally reprehensible and intrinsically wrong? There may be a few crimes like murder, child pornography or rape over which there may be some consensus regarding immorality, but there remains a legion of criminal offences whose morality invites diversity of views.

In this regard the court simply concluded that contempt of court is morally reprehensible and intrinsically wrong without any analysis of or reference to the prevailing moral sentiments in Malawi. The key question of whether the Malawian community finds contempt of court to be morally reprehensible and intrinsically wrong was not even asked. Thus the inquiry into moral turpitude invites judges to set inconsistent moral standards and there is no legal definition of which crimes will lead to the disqualification of a candidate. 
The court in the Tembo and Kainja case also indicated that section 51(2)(c) does not violate political rights under section 40 of the Constitution. The court also discussed the purpose of the section and indicated that the provision should ensure that undesirables such as rapists, defilers and armed robbers not be elected to the National Assembly or, if already there, ensure their removal from Parliament. This statement appears to suggest that in the court's view the offences of rape, defilement and robbery are crimes involving moral turpitude. It is however debatable as to whether the section excludes undesirables. Another question is, undesirable from whose perspective? In the case of Yeremiah Chihana (Civil Cause Number 41 of 2009) (discussed below) the applicant had been nominated and therefore approved by his constituents, yet he was rejected by Malawi Electoral Commission (MEC) on the basis of section 51(2)(c). Again, regarding the seven-year limit, what is magic about this number? Does a person cease to be an undesirable with the passing of seven years? These questions and more remain unanswered. Nevertheless this case remains a significant authority on crimes involving moral turpitude in Malawi.

Shortly after the High Court judgment, the Tembo and Kainja case proceeded to the Supreme Court of Appeal. The Supreme Court held an extensive discussion on whether the contempt of court in issue was a crime or a civil wrong and unanimously decided that the contempt in issue was a civil not a criminal wrong. The court proceeded to hold that, having determined that the contempt was not criminal and therefore outside the ambit of section 51(2)(c) as read with 63(1(e), 'we do not see any need to go through the academic exercise of determining whether or not the contempt involved moral turpitude or dishonesty'.

It is regrettable that Malawi missed an opportunity to hear the views of the highest court in the land on crimes involving dishonesty and moral turpitude. As the Supreme Court said nothing about the High Court's views on the meaning of crimes involving dishonesty or moral turpitude and whether criminal contempt involves these elements, and in the absence of any other relevant authorities, we take the view that the High Court judgment in this case is still valid on this point.

In 2009, another opportunity arose in the case of Yeremiah Chihana for the High Court yet again to determine section 51(2)(c) and the meaning of crimes involving dishonesty and moral turpitude. Interestingly, the same judge was sitting as in the previous case. In this case the applicant was convicted of the offence of unlawful wounding and sentenced to 18 months imprisonment, reduced to 14 months on appeal. It was alleged that he did not serve the full sentence owing to a presidential pardon. In 2009 the applicant was nominated by the Alliance for Democracy (AFORD) party for election as Member of Parliament (MP). When he presented his nomination papers to $\mathrm{EC}$, they were rejected on the basis of his conviction. The key issues for the court's determination were, inter alia, whether 
the applicant should have been heard before the decision disqualifying him was made and secondly whether unlawful wounding is a crime involving moral turpitude.

Regarding the first question, the court held that a person whose eligibility is at stake should be afforded the right to be heard as guaranteed by section 43 of the Constitution. Since this had not been done, the decision to bar Mr Chihana was taken in breach of his right to be heard and was therefore void. When the same question arose in the Tembo and Kainja case, viz, whether the National Assembly had afforded the plaintiffs the right to be heard, the court indicated that the plaintiffs automatically lost their seats the moment they were convicted of a crime involving dishonesty or moral turpitude and that it was not necessary to determine whether or not they were heard.

The latter decision seems correct in our view. The decision to bar someone from standing as MP, councillor or president or to remove such person affects the person and his or her constituent rights, freedoms, and legitimate expectations or interests, so as to warrant compliance with the right to be heard under section 43 of the Constitution.

The court also indicated that section 51(2)(c) is about more than the applicant's candidature or eligibility to stand. It concerns the applicant's right to stand for elective office, his right to vote and the right of persons in his constituency to vote for a candidate of their choice as guaranteed by section 40 of the Constitution. Subsequent paragraphs discuss whether section 51(2)(c) is a justifiable limitation to section 40 .

Secondly, the court indicated that the MEC has no power to disqualify anyone simply because they have a criminal conviction. It has to be a conviction for an offence involving dishonesty or moral turpitude. This was in response to the fact that MEC had simply written to the applicant that his nomination was ineligible following his conviction by a competent court of law, without specifying whether the conviction was for a crime involving dishonesty or moral turpitude The court refused to determine whether unlawful wounding was a crime involving moral turpitude on the basis that firstly, such determination was irrelevant to the resolution of the matter; and secondly, that the words moral turpitude and dishonesty keep appearing in the courts for determination and the court did not wish to burden other judges with its opinions.

This was yet another missed opportunity to further clarify the law on this point. The court's definition of the words in Tembo and Kainja therefore remain relevant. There have, however, been other cases where the courts discussed moral turpitude, though not in relation to elections and the holding of political offices. In $R V$ Gondwe ((1964-1966) ALR Mal 247) for instance, the court stated that theft of money was a felony of grave moral turpitude. The recent case of Symon Kamuna 
(Confirmation Case Number 669 of 2002; R V Manyozo Confirmation Case Number 431 of 2002) declares that simple theft is not an offence of moral turpitude. This further evidences the inconsistencies in court application of the moral turpitude standard. Thus the phrase moral turpitude remains vague even after attempts to define it; yet it is a script that will keep replaying in our courts.

\section{CONSTITUTIONALITY}

Section 40 of the Malawian Constitution makes provision for political rights in Malawi, including the following guarantees: the right to participate in peaceful political activities intended to influence the composition and policies of the government; the right freely to make political choices; the right to vote; and the right to stand for any elective office. In the Tembo and Kainja case, the plaintiffs argued that their expulsion from the National Assembly was a violation of their political rights in terms of section 40 of the Constitution.

The judge indicated, correctly in our view, that the rights under section 40 can be limited as long as such limitation complies with section 44(1) of the Constitution. This section provides that a limitation shall only be lawful if it is prescribed by law; is reasonable; is recognised by international human rights standards; and is necessary in an open and democratic society. Referring to its previous decision in the case of Maggie Kaunda (Criminal Appeal Number 8 of 2001) the court stated that, with regard to limitations, it is necessary to establish firstly, if the plaintiff's right or freedom has been infringed; and secondly, if the limitation complies with section 44(1). With respect to the first question, the court held that depriving the plaintiffs of the right to participate in the activities of the National Assembly was a clear infringement of their political rights. We concur with the court that barring someone from standing for election, or removing them from their position on the basis of a crime involving dishonesty or moral turpitude, is prima facie an infringement of the person's right to stand for election for any elective office and also the right of his or her constituents to vote for or be represented by a person of their choice. This is more so where the person is barred after nomination, as happened in the Yeremiah Chihana case, or where the person is removed after election. The right to participate in peaceful political activity intended to influence the composition and policies of the government is also infringed.

The key question is whether this infringement complies with section 44(1) and is therefore lawful. In the Tembo and Kainja case, the court answered this question in the affirmative, asserting that that limitation was lawful because section 51(2)(c) as read with section 63(1)(e) serves the legitimate aim of protecting the integrity of parliament by eliminating undesirable people. The court further 
indicated that the limitation is legal because it does not impose a blanket ban on all political rights. The plaintiffs were free to engage in political activities and to exercise their political rights in other ways or areas other than parliament. The court therefore held that there was a reasonable proportionality between the means used i.e. disqualifying/removing people convicted of crimes involving dishonesty and moral turpitude, and the aim of keeping people of bad character out of parliament. The court therefore concluded that section 51(2)(c) was a lawful limitation under section 44 of the Constitution.

Having established that disqualification or removal on the basis of a conviction for a crime involving moral turpitude infringes section 40 rights, it is incumbent to critically analyse this disqualification against section 44(1) to determine if this is indeed a lawful limitation and therefore constitutional. Any lawful limitation of constitutional rights must comply with all the requirements prescribed by section 44(1) of the Constitution (Wavunduka Mwenitete V Fishani Mkandawire Civil Appeal Number 29 of 2000). That is, it must be prescribed by law, reasonable, recognised by international human rights standards and necessary in an open and democratic society.

\section{Prescribed by Law}

Section 44(1) stipulates that a lawful limitation must be prescribed by law. The European Court of Human Rights has held that a law cannot be regarded as 'prescribed by law' unless it is formulated with sufficient precision to enable the citizen to regulate his conduct (Sunday Times $V$ the UK 2 EHRR 245). As discussed above, the phrase 'crimes involving moral turpitude' is notoriously vague. Malawian citizens and their constituents are not given definite notice of which exact crime warrants disqualification to the said offices. Whether a particular crime is regarded as a crime involving moral turpitude and therefore disqualifies a candidate depends on the moral reactions of the judge sitting. This is untenable and we submit that crimes involving dishonesty or moral turpitude are not prescribed by law and therefore fail the section 44(1) test.

\section{Reasonable Limitation}

Is a disqualification for election as councillor, MP or president on the basis of a conviction involving dishonesty or moral turpitude within the last seven years a reasonable limitation? Chirwa (2011, p. 48) indicates that at the very minimum, reasonableness demands that laws should not be arbitrary and that the limitation must be rationally connected to its stated objectives. The analysis above has already established that the phrase is grossly ambiguous. The legislature struggled to make 
sense of it and courts have struggled to attach a definite meaning to it. Morality is so fluid a concept that even courts are not competent to gauge it accurately, particularly in a pluralistic society, and though courts have tried to define this phrase, their definitions are also amorphous. This goes for the Tembo and Kainja case too. Consequently the phrase is applied unevenly. Even with respect to the same offence some judges will regard it as involving moral turpitude while others have the opposite view. Which particular crime involves enough moral turpitude to warrant disqualification for elections or removal from office, depends on the personal moral view of the sitting judge. The persons concerned are not given definite notice. We submit that subjecting someone's right to be elected to office, and the constituents' right to vote for someone of their choice (ie for a nominated candidate) to the whim of the sitting judge is a sufficiently arbitrary application of a law for us to question the law's reasonableness.

Secondly, the law in issue is not reasonably connected to its supposed objectives. Justice Chikopa argues that the law in the Tembo and Kainja case is meant to protect the integrity of parliament by eliminating so-called undesirables from parliament. We argue that integrity is so intrinsic a matter that the lack of a conviction involving dishonesty or moral turpitude does not guarantee this protection. Stories are rife in Malawi of sitting parliamentarians involved in corruption and other dubious activities. Are such people desirable just because they have never been convicted of a crime involving dishonesty or moral turpitude? What of the person who is convicted of a crime involving dishonesty or moral turpitude but has such conviction overturned on appeal on a technical point of law?

The law's supposed purpose is also undermined by candidates like Yeremiah Chihana who were duly nominated by their constituents. We consider that the disqualification undermines such constituents' right to vote for a person of their choice. People do not vote for a candidate to contribute to a national assembly comprised of persons of moral uprightness and integrity. They vote for candidates they consider may represent them in parliament and deliver their developmental needs. There may also be tribal motivations in Malawi. There is thus no guarantee that a representative without a criminal record can serve the people better than a previous convict. A criminal record has nothing to do with the ability to ably represent and deliver proper services to one's constituents.

There is no evidence that character matters in the choice of political leaders for the Malawian electorate. A few days before Malawi's first multiparty general elections in 1994, Malawi was awash with a story involving one of the strongest contenders for the election, Dr Bakili Muluzi. In 1968 Muluzi had been convicted of stealing 6.10 pounds sterling while working as a court clerk at Nsinja traditional court in Lilongwe. He served a prison sentence of six months. Less than a week 
before the election, the Malawi Democrat carried this story on its front page, with full details and a picture of Muluzi in prison uniform. This newspaper was sponsored by the AFORD party whose Chakufwa Chihana was a strong contender for the elections and was generally regarded as the candidate with an impeccable record of integrity. He was considered the more principled of the two, a family man, a trade unionist, human rights activist and a pro-democracy advocate. The paper running this story was widely circulated and freely distributed in communities to ensure wide dissemination of the scandal. Muluzi chose not to respond to these allegations and went on to win the election with $47 \%$ of the vote, becoming Malawi's first democratic president and emerging as a charismatic leader. This incident is probably why section $80(7)(c)$ was hotly contested during the 1995 constitutional conference.

In addition, in 2004 Muluzi's UDF won the election under Bingu wa Mutharika who was himself handpicked by Muluzi. This was despite the fact that Muluzi and other key UDF figures were not exactly paragons of virtue. During the run up to the 2004 election, further damning allegations of corruption, theft of public funds, abuse of office and womanising involving Muluzi were released by his chief economic adviser and business partner, Kalonga Stambuli.

Another example is that of Yeremiah Chihana who was nominated as a candidate for AFORD by his constituents when memories of his conviction for unlawful wounding were still fresh. Members of parliament have often been reelected into parliament by their constituents despite scandalous stories associated with them, involving even corruption.

This proves the point that good character alone is not a strong determinant for the choice of a candidate by the Malawian electorate. Should the right to stand for elective office and the right of constituents to vote and be represented by a person of their choice be limited on the strength of such a nebulous concept whose objectives do not matter to the electorate and which is not even guaranteed to achieve its purported aim? We think not. To disqualify a candidate convicted of a crime involving dishonesty and moral turpitude for the purpose of protecting the integrity of parliament in these circumstances does not seem reasonable. It is therefore submitted that these provisions are not a reasonable limitation of the rights concerned.

In additional, the case of Maggie Kaunda (Criminal Appeal Number 8 of 2001) states that reasonableness also entails that there be proportionality between the limitation and its aim. Specifically, the limitation must be capable of achieving its purpose and also not unnecessarily impinge on human rights in achieving its objective. On this basis, assuming that good moral character matters to the Malawian electorate, it is possible to protect the integrity of parliament by enacting a precise provision that can be applied without arbitrariness, uncertainty 
or unpredictability. Other countries such as South Africa and Namibia use unambiguous words and phrases, e.g. 'convicted of a crime punishable with a prison sentence without the option of a fine'. The provisions at issue cannot therefore pass the reasonableness test under section 44(1).

\section{Recognition by International Human Rights Standards}

While it is unclear whether the state needs to demonstrate that a particular limitation is recognised in international law and domestic jurisdictions, evidence that the limitation is rarely found in comparative human rights law will undermine its necessity (Chirwa 2011, p. 49). The state has to prove that the limitation is recognised in international law or by a significant number of democratic states (ibid.). In this regard, it must be noted that only a few African countries (Ghana, Uganda and Libya) have provisions disqualifying candidates convicted of crimes involving moral turpitude from political office (see constitutions of Ghana and Libya; IFES 2011 report on elections in Libya). While most African countries have constitutional provisions disqualifying previously convicted persons from election to parliament or the presidency, they do not disqualify candidates on the basis of a conviction involving dishonesty or moral turpitude. The disqualification is usually for crimes punishable by death or imprisonment without the option of a fine ${ }^{3}$. Tanzania and Nigeria have constitutional provisions disqualifying persons from the presidency and legislative houses if they have been convicted of a crime involving dishonesty, but no reference is made to moral turpitude. Only a negligible number of African countries apply the principle of moral turpitude to elections and the holding of political office. Within the Southern African Development Community (SADC) region, disqualification on the basis of moral turpitude seems to be peculiar to Malawi. On this premise we submit that this is an unnecessary limitation not generally recognised by international human rights standards.

\section{Necessary in an Open and Democratic Society}

To begin with, the case of Jumbe and another (Constitutional Case Numbers 1 \& 2 of 2005) noted that the term 'open and democratic society' is not easy to define. Paragraph 20 of the Siracusa principles (1985) indicates that the term 'in a democratic society' demands that states should show that limitations do not impair the democratic functioning of the society. The provision also entails that the limitation at issue must serve a legitimate purpose which is necessary in

3 See the constitutions of Zambia, Zimbabwe, Lesotho, Swaziland, Botswana. 
an open and democratic society (Jumbe case). In answering the question as to whether a limitation is necessary in an open and democratic society, Malawian courts consider whether the limitation promotes the fundamental principles of the Constitution or principles of national policy (Chirwa 2011, p. 52; Attorney General $\mathcal{E}$ another V Malawi Congress Party \& others [1997] 2 MLR 181; Friday Jumbe case). It is a fundamental principle of the Malawian Constitution that the authority to govern derives from the people and shall be exercised in accordance with the Constitution solely to serve and protect their interests. To the extent that the provisions in issue undermine the constituents' right freely to make political choices and the right to vote for a person of their choice, it is submitted that they impinge the democratic functioning of society and the fundamental right of people to choose their leaders. On that account again, we find this limitation unjustifiable.

Overall, it is submitted that, having failed the tests stipulated in section $44(1)$, disqualifying candidates convicted of a crime involving dishonesty or moral turpitude in the last seven years is an unjustifiable limitation of the right to participate in peaceful political activities intended to influence the composition and policies of the government; the right freely to make political choices; the right to vote; and the right to stand for any elective office as guaranteed by section 40 of the Constitution. It is therefore recommended that this disqualification should be removed from the Constitution.

\section{POSSIBLE APPROACHES TO IDENTIFYING CRIMES INVOLVING MORAL TURPITUDE}

While it is recommended that the disqualification for election on the basis of a conviction involving dishonesty or moral turpitude be removed altogether from the Constitution, it is necessary also to explore other viable alternatives to the problem. A variety of tests have been used or proposed to clarify this nebulous phrase and help identify crimes involving moral turpitude. These alternatives are discussed below in relation to their viability in the Malawi legal system.

Firstly, in the case of Luyimbazi \& Kasirye $V$ Bazigatirawo \& the Electoral Commission of Uganda (HCT-00-CV-EP-0044 of 2011) the High Court of Uganda has adopted a unique approach to interpreting crimes involving moral turpitude by using the standard of a reasonable man in the accused's community. Other than the local cases cited above, this seems to be the only case interpreting crimes involving moral turpitude in relation to elections on the African continent. In this case the respondent was nominated and won local council elections by a large margin. He had recently been convicted of assault causing actual bodily harm and sentenced accordingly, having slapped another man after a heated political argument. The applicants who lost the elections challenged his victory on the 
basis that the respondent had, within seven years preceding the nomination, been convicted of a crime involving moral turpitude contrary to Section 80 (2)(f) of the Ugandan Constitution.

Relying on the Malawian cases quoted above as well as American jurisprudence, the court indicated that moral turpitude is an elusive concept incapable of precise definition. It held that the standard of a reasonable man in the convict's community would be appropriate. On this basis the court went further to hold that slapping another person following an argument is not conduct so 'depraved, vile and base as to shock the Mubende people' as proved by the fact that they nominated and overwhelmingly voted for the respondent despite knowing of his conviction. This ruling was upheld by the Ugandan Court of Appeal (election petition appeal number 40 of 2011). As indicated above, in making moral assessments of the crimes in issue, Malawian judges have not made any reference to the community's moral sentiments. The Ugandan approach, though it does not fully address the ambiguity surrounding moral turpitude, mitigates the problem by ensuring that judges use an established yardstick applicable to a specific community.

Secondly, American jurisprudence has now adopted the categorical approach to interpreting crimes of moral turpitude. The categorical approach considers if moral turpitude is necessarily inherent in a conviction under a particular law without regard to the specific circumstances of the offence (Salem 2018, p. 233; Dadhania 2011, pp. 313-355). Here the court examines the particular law under which the person was convicted to determine whether such law categorically involves moral turpitude. If the least culpable conduct that can sustain a conviction under a particular law involves moral turpitude then that statute categorically involves moral turpitude without even considering the convict's actual conduct (ibid.; Frank 2017, p. 578). The Tembo and Kainja case adopted this approach. Nevertheless, this approach entails that the court should undertake the difficult task of determining if moral turpitude inheres in a particular crime, and then categorise it accordingly. This may invite judges to hypothesise whether moral turpitude is inherent in the nature of a particular crime and is still ambiguous. The categorical approach also hampers useful flexibility in the sense that once there is a finding that moral turpitude does not inhere in a particular statute it matters not that the offence was committed in aggravating or deplorable circumstances. To a large extent, however, the categorical approach enables courts to avoid the difficult task of making moral assessments.

A third way to mitigate the ambiguity and identify crimes involving moral turpitude is actually the opposite of the categorical approach. This is to look at the actual circumstances of a particular case and the facts underlying it and determine if it was committed in such a way that it can be said to involve moral 
turpitude (Marchiano 450 F. 2d.1025). Here every case turns on its facts. If a felony has been committed in excusable circumstances, for example killing in selfdefence, then it does not involve moral turpitude. Alternatively, if a misdemeanor has been committed in aggravating circumstances then it can be said to involve moral turpitude regardless of its classification. While this can be said to be a fair approach for the convict, it still hampers uniformity and predictability because it is premised on the judge's subjective assessment of the facts of a particular case.

A fourth possible alternative to identifying crimes of moral turpitude is to simply regard every felony as a crime involving moral turpitude, but not misdemeanors. It has been argued that the law takes into account the degree of moral turpitude in fixing punishment for a crime (Riddall 1999, p. 308). The problem with this approach is that felonies and misdemeanours are categorised according to the degree of punishment and not the nature of the act (Bradway 1935, p. 923). This becomes problematic when a felony is committed under excusable circumstances or a misdemeanor is committed in aggravating and deplorable circumstances.

A fifth approach to identifying crimes of moral turpitude has been to consider the mental element accompanying its commission. If the crime committed involves reprehensible conduct and it is committed with specific intent, willfulness or knowledge then it is regarded as involving moral turpitude (Dhadania 2011, pp. 313-355). Here, evil or malicious intent is the determining factor. Statutes that are regulatory in nature or which do not have an intent requirement, such as strict liability offences, are regarded as not involving moral turpitude. On the other hand, crimes committed knowingly or with evil intent are considered to involve moral turpitude (Moore 2008, p. 825). The best advantage of this approach is that it enables judges to avoid making moral value judgments, while its key disadvantage is that it hampers flexibility in decision-making which can be helpful especially for misdemeanors requiring evil intent.

A sixth recommended approach is to distinguish between crimes involving moral turpitude and those not involving moral turpitude. This has been the case in Alabama, where crimes of moral turpitude have been used to disenfranchise and the law now provides a list specifying which crimes involve moral turpitude and which do not. It has been suggested that the Malawi legislature should adopt this approach and clearly list the offences that involve moral turpitude and those that do not (Bande 2017, p. 83). While this removes guesswork and discretion and provides useful insight, the question remains as to what informs the decision as to which crimes should be on the list? It should also be borne in mind that such lists are never exhaustive and other approaches may still be needed to supplement the inquiry into excluded offences. These lists may be unduly restrictive as there are many situations where an offence may have been committed in excusable circumstances. 
Finally, common law crimes were also classified as malum in se and malum prohibitum. This distinction has also been used to differentiate crimes involving moral turpitude from those that do not involve moral turpitude (ibid., 81). Malum in se means 'evil in itself' and refers to an act that is inherently immoral like murder or rape (Garner 2007, p. 978). Crimes malum in se were and are generally considered crimes of moral turpitude. Malum prohibitum means 'prohibited evil' and refers to acts that are criminal merely because they are prohibited by the law though the acts themselves are not immoral (ibid.). For example, regulatory offences like road traffic violations are generally not regarded as crimes involving moral turpitude because they do not invite adequate moral condemnation (Salem 2018, 232). We submit that this distinction is not precise enough to solve the moral turpitude ambiguity nor flexible enough to allow changes where an offence malum in se is committed in excusable circumstances, or malum prohibitum is committed in inexcusable circumstances

\section{CONCLUSIONS AND RECOMMENDATIONS}

This paper set out to critically analyse crimes involving dishonesty or moral turpitude in relation to elections and the holding of political office in Malawi. It has established that, although the Constitution and the LGE Act disqualify people for election and make them removable if they are convicted of a crime involving dishonesty or moral turpitude, the term moral turpitude is ambiguous. Local Malawian and international courts have tried unsuccessfully to define this phrase, and consequently it is unevenly applied. The paper has also established that this disqualification is an unlawful limitation of the right to participate in peaceful political activities intended to influence the composition and policies of the government; the right freely to make political choices; the right to vote; and the right to stand for any elective office as guaranteed by section 40 of the Constitution.

While different approaches to addressing the ambiguity around moral turpitude have been explored, they all present various weaknesses that undermine their efficacy. It is therefore recommended that the best way forward is to delete this disqualification from the Constitution and the LGE Act altogether. The electorate is quite capable of making its own choice and should be afforded the opportunity to do so. The Muluzi saga is adequate proof. The freedom to make political choices imposes an obligation on the state to ensure that people are empowered to make informed political decisions (Chirwa 2011, p. 389). The best way for this is to permit all candidates to contest the election and let the voters decide after providing them with all relevant information, including information on criminal records. Should they elect someone with a criminal record then let that be their call. 


\section{--_-- REFERENCES}

Ali v Mukasey 521 F 3d 737, 739 (7th $C$ ir 2008)

Attorney General \& another V Malawi Congress Party\& others [1997] 2 MLR 181

Bande, LC 2017, Criminal law in Malawi, Juta, Cape Town.

Bradway, JS 1935, 'Moral turpitude as the criterion of offences that justify disbarment' California Law Review, vol. 24, no. 1, p. 923.

Chirwa, D 2011, Human Rights Under the Malawian Constitution, Juta, Cape Town.

Dadhania, PR 2011, 'The categorical approach for crimes involving moral turpitude after Silva-Trevino', Columbia Law Review, vol. 111, no. 2, pp. 313-355.

Frank, G 2017, 'On moral grounds: denouncing the board's framework for identifying crimes of moral turpitude', Akron Law Review, vol. 51, no. 2, p. 578.

Friday A Jumbe and Humphrey C Mvula V Attorney General Constitutional Case Numbers 1 \& 2 of 2005 (unrep.)

Garner, BA 2007, ed., Black's Law Dictionary, $8^{\text {th }}$ ed, West Publishing Company, St Paul.

Genovese, S 2018, 'Vague laws invite arbitrary power: making the case for crimes involving moral turpitude being void for vagueness' available at $<$ http:// www.lexisnexis.com/legalnewsroom/immigration/b/immigration-law $>$. [13 December 2018].

Ghani V Holder 557 F. 3d 836 (7th Cir. 2009)

Goldeshtein V I.N.S. 8 3d 645 (9 ${ }^{\text {th }}$ Cir 1993)

Hirsch V Immigration \& Naturalisation Serv 308 F. 2d 562 (9 $9^{\text {th }}$ Cir 1962)

Johnson V US 2015 US Court of Appeals, $8^{\text {th }}$ Cir.

Jordan V De George 71 S. Ct 703 (1951) Per Justice Jackson, dissenting

Juan Antonio Montero-Ubri V Immigration and Naturalisation Service case number 00-1133 ( $1^{\text {st }}$ Cir).

Luyimbazi \& Kasirye V Bazigatirawo \& the Electoral Commission of Uganda HCT-00CV-EP-0044 of 2011);

Marchiano 450 F. 2 d.1025

Matter of Franklin, deportation proceedings (A-40191863, 1994)

Matter of Perez Contreras, 20 I \& N Dec 615, 617-18 (BIA 1992)

Matter of Tejwani, 24 I \&BN Dec 97 (BIA 2007)

Moore, D 2008, 'Crimes involving moral turpitude: why the void for vagueness argument is still available and meritorious', Cornell International Law Journal, vol. 41, no. 3, p. 812.

Partyka V AG of US 417 F. 3d 408, 409 (3 ${ }^{\text {rd }}$ Cir 2005)

People v Castro 696 P. 2d 111, 134 (Cal.1985)

Riddall, JG 1999, Jurisprudence, Oxford University Press, Oxford.

R V Gondwe ((1964-1966) ALR Mal 247 
R V Maggie Kaunda (Criminal Appeal Number 8 of 2001)

$R$ V Manyozo Confirmation Case Number 431 of 2002)

$R$ V Symon Kamuna (Confirmation Case Number 669 of 2002

Salem, S 2018, 'Should they stay or should they go: rethinking the use of crime involving moral turpitude', Florida Law Review, vol. 70, p. 225.

Simon-Kerr, J 2012, 'Moral Turpitude', Utah Law Review, vol. 2, p. 1001.

Tembo and Kainja V Attorney General [2002-2003] MLR 229 HC

The state and Malawi Electoral Commission Ex parte Yeremiah Chihana, Miscellaneous

Civil Cause Number 41 of 2009 (Mzuzu Registry)

The Sunday Times $V$ the UK 2 EHRR 245

Wavunduka Mwenitete V Fishani Mkandawire Civil Appeal Number 29 of 2000 (Unrep). 


\title{
ELECTORAL VIOLENCE AND YOUNG PARTY CADRES IN ZAMBIA
}

\author{
Kabale Ignatius Mukunto \\ Kabale Ignatius Mukunto is a lecturer at the \\ Dag Hammarskjöld Institute for Peace and Conflict Studies, \\ Copperbelt University, Kitwe, Zambia
}

\begin{abstract}
Zambia's 2016 general elections were a turning point in the country's political history, with electoral violence threatening its democratic fabric. This paper analyses accounts of electoral campaigns by one private online newspaper, the Lusaka Times, to reflect on the relationship between electoral violence and young party cadres. Evidence from the study indicates that negative socioeconomic conditions, leadership manipulation and incentives as well as the perception of plural politics all contribute to the susceptibility of young people to electoral violence. The violence witnessed in 2016 included molestation and intimidation, seizure of public property, public disorder, vandalising of party property, lawlessness and aggressive rhetoric. The paper also notes that events of 2016 were counterweight to the consolidation of democracy as the activities of young party cadres undermined the free political participation of other stakeholders.
\end{abstract}

Keywords: electoral violence, electoral campaigns, young party cadres, Zambia

\section{INTRODUCTION}

Ascent to power through an election is assumed to legitimise those in government. Elections are considered a neutral arbiter for the contending parties and to some extent instil confidence in political players. Conversely, voters see considerable incentive in being part of the process to usher in their preferred candidates to facilitate improved service delivery. Elections constitute a transitional mechanism at the core of democracy, ideally supporting all institutions. Yet, if the behaviour of participants in this process is not regulated, attendant returns such as peace and security are imperilled. In spite of a seemingly peaceful record of elections, Zambia's last two elections (in the presidential by-election of January 2015 and 
the general elections of August 2016) present an ugly trend of election-related violence. The rank and file of major political parties - their political cadres - are now frequently implicated in election-related violence. The behaviour of these young men and women in recent elections has led to attention-grabbing headlines in both print and electronic media. Some of these accounts question the value of their participation in the country's democratic institutions and political culture.

Consistent with these concerns, Omotola (2010) notes that electoral violence is a major source of democratic instability with substantial threats of deconsolidation. Thus, the trend not only poses a threat to the sustainability of a country's democratisation process but also jeopardises future political culture. This paper is motivated by the fact that Zambia's past two elections have been characterised by an emerging trend of violence that peaked during the campaigns and the immediate post-election period. This tendency presents a troubling departure from previous elections that witnessed less pre- and post-electionrelated violence.

The paper draws on empirical evidence from Zambia's political events in 2016 to explain the relationship between electoral violence and members of the political party youth league, including pertinent questions that merit critical consideration. For instance, why are young political party members drivers of electoral violence? What form does electoral violence take? What bearing has electoral violence on the consolidation of democracy? But first, it is essential to have an appreciation of what constitute electoral violence.

\section{UNDERSTANDING ELECTORAL VIOLENCE}

Within the realm of peace and conflict studies there is an intrinsic connection between conflict and violence and to understand electoral violence it is necessary to explain political conflict. Political conflicts are defined as being driven by the need to alter political, economic or cultural structures (Barber 2013, p. 338). Consistent with this, political violence is a development of political conflicts which those seeking change seldom avoid. Thus, political violence is explained as the use of force by a group with a political purpose or motivation or influenced by political matters. It encompasses but is not limited to violence against civilians or political rivals as well as violent demonstrations (Paalo 2017).

Electoral violence is in turn an offshoot of political violence, defined by its timing and intent. Adolfo, Kovacs, Nyström and Utas (2012, p. 2) argue that electoral violence is a forced and premeditated approach employed by both incumbent and opposition political actors propelled by the attainment of specific objectives associated with electoral competition. The occurrence of electoral violence is not restricted to physical confrontation but includes other aggressive 
tactics including threats of violence, harassment and intimidation. Based on the motivation of its perpetrators, electoral violence can be divided into different classes.

Burchard (2015) for example, categorises this sort of violence into 'incidental and strategic'. She argues that incidental electoral violence ensues as an outgrowth of protest and electoral events prior to or just after an election when tensions are high and opposing parties are still in close proximity. Strategic electoral violence, on the other hand, is premeditated and engaged in for a multiplicity of reasons, one being to influence the outcome of an election.

In addition, electoral violence may be neatly compartmentalised into three integral aspects: the point at which it takes place; the perpetrators and victims involved; and the form it takes. For instance, Birch and Muchlinski make the following distinction:

... between violence that happens before, during and after the month in which the election occurs, violence perpetrated by state, non-state, and international actors, and violence that causes actual physical harm, or is instead employed to coerce, restrict, or otherwise influence electoral processes through methods that fall short of physical force.

(Birch \& Muchlinski 2017, p. 4)

Other sources identify both structural and institutional factors as triggers of electoral violence. For instance, Adolfo et al. (2012), cite 'informal patronage systems and exclusionary politics as well as the uncertainties associated with losing political power among other aspects responsible for electoral violence'. Institutional sources, they claim, is manifest in 'failed or flawed elections, election fraud and weak or manipulated institutions or institutional rules' that direct the electoral process. However, there are occasions with autonomous institutions when, as Fjelde and Hoglund claim (2014, p. 301), prospects of electoral defeat should not be sufficient to drive politicians to participate in violent electoral tactics.

Although electoral violence is characterised by an array of strategies that different political players use at stages of the electoral cycle, some see it more broadly. Fjelde and Hoglund (2014, p. 307) argue that electoral violence should be identified by issue(s) in addition to timing. They assert that while electoral violence can occur at any time in the course of an electoral cycle, there may be candidate intimidation during primaries which would occur before electoral campaigning and voting.

In terms of its effects, electoral violence accounts for protracted incumbent legitimacy crises, socioeconomic turbulence, the risk of armed uprising, a culture of impunity for the perpetrators, population displacement and humanitarian 
emergencies, and a loss of confidence in the electoral process, including impending effective political competition and participation (Adolfo et al. 2012; Leonard 2010; Omotola 2010). Participation is particularly significant given its bearing on the political life of the youth, discussed in the following section.

\section{ELECTORAL VIOLENCE AND THE YOUTH}

The extent of young political party cadres' involvement in political violence stretches from a mere exchange of insults between different political groups, to relaying intelligence information. For example, a study of political youth leagues in Burundi revealed that the youth had tasks such as mobilising followers, collecting money and relaying intelligence (Berckmoes 2015). However, political violence is at its height during elections. This period illuminates both the indispensability of political youth wings and the full extent of their thuggery with acts that include snatching ballot boxes, voter and opponent intimidation, breaking up opposition rallies, and seizing the voter cards of perceived opponents (Okafor 2017; Paalo, 2017). In addition, political violence among the youth is characterised as a practice whereby political leaders manipulate and mobilise young people to perform violent acts in order to realise and further their own political objectives (Umar 2016, p. 147).

The prevalence of this violence is seen as one of the hallmarks of Africa's political landscape; in Africa, political violence is perpetrated at ground level by the youth. In the view of Okafor $(2017$, p. 2), 'this appears in the form of political thuggery which has been seen as criminalization of politics'. Okafor defines political violence in Africa as taking different forms in different areas in the quest to lure youths into such conduct, either as hired thugs or as party members.

In addition, in the pre-election period the political activities of young people may be associated with 'unlawful seizure and control over facilities of public good such as bus terminals and markets to seek rents for themselves and the political elite' (Paalo 2017, p.7). Paalo further claims that they also exhibit what is known as 'destructive engagements' such as vandalising public property; rioting and violent protests, seizure and control of public property. These and many other expressions of political conflict and violence are driven by a myriad of factors, three of which merit discussion.

First, the unfavourable socioeconomic conditions of young people including unemployment, poverty, lack of good education and institutional structures, and a lack of access to modern facilities (Akpan 2015). Due to high levels of poverty, unemployment and general deprivation, young people are vulnerable to what Akpan describes as the recruitment and arming by bourgeois politicians to serve as political thugs and assistants during elections. This section of society remains 
a principal factor in a country's stability before and after election periods when left to the whims of political party expediency. Forti and Maina (2012) note that there are dangers in ignoring and marginalising youth constituencies, especially in situations with weak societal institutions and infrastructure. Based on their reflections about Kenyan youths, Forti and Maina stress that the precarious situation of many young people is exacerbated by their weak socioeconomic status. Herein lies their vulnerability to manipulation and exploitation.

Second, political leadership and its related aspects are said to be responsible for young people's inclination to act violently. For instance, in West Africa the concept of Godfatherism is relatively common. Godfathers, according to Akpan (2015, p. 152) are influential politicians who command respect in public because of their material possessions, wealth and charisma. Akpan adds that their actions range from arming their boys who in turn snatch ballot boxes, to killing and maiming where their actions are obstructed. Further, others claim that Godfathers remain a factor in the perpetuation of political violence through their financial support of young people (Okafor 2017, p. 2).

Third, young people's appetite for political violence is driven by their perception of plural politics and the application of violence. Researchers and observers of young peoples' participation in political violence argue that many youths do not understand the meaning of multiparty politics. Their rudimentary appreciation is instead dictated by their political masters who arm them to kill and maim when the election pendulum swings against the former. It is these acts that contribute to the normalisation of violence among some young people. Political elites invariably recruit marginalised young people and socialise them in these 'norms' of violence in order to maintain existing power structures, notes Umar (2016).

In sum, marginalisation of young people from mainstream politics and their restriction to the fringes of the democratic processes generates a lasting effect. This, according to Okafor (2017, p. 3) is counterweight to democratic development as it continues to undermine the essence of democracy in Africa. Zambia, with its fledgling democratic system, warrants an appraisal of its young political players and the contribution of its cadres in shaping its development.

\section{YOUNG PARTY CADRES IN ZAMBIA}

From the time of Zambia's independence in 1964 and its first republic under the ruling political party, the United National Independence Party (UNIP), youth leagues in particular have greatly influenced the political outlook. Their functions and responsibilities were then to serve as guardians of moral standards by intervening in any aspect of community affairs (Chiluba 1995; Scott 1976). Beyond 
community matters, they were also at the helm of what Phiri (2001) called an oppressive card-checking campaign. Men and women without UNIP cards were denied access to markets, shops or public transport to and from work, while under UNIP's one-party state rule the UNIP youth members were considered above the law, claims Phiri.

As members of UNIP's youth league, some party stalwarts were allegedly involved in attacking and burning the houses of those perceived as belonging to the opposition. While Zambia's transition from one-party state to multiparty democratic dispensation has been described as 'free of violence' and a 'masssupported pact', there are some outliers that merit mention (Erdmann \& Simutanyi 2003). For example, observers of the 1991 general elections shared some of the pre-election violent incidences, as follows:

...upon arrival at a soccer match in July, Kaunda and his entourage were pelted by fans throwing stones, bottles and fruit. At the home of Dipak Patel, a prominent Lusaka businessman running for parliament on the MMD ticket, unknown assailant severely beat a security guard and destroyed two vehicles. In Eastern Province, a UNIP stronghold, there were frequent reports that huts and granaries of MMD sympathisers were being burned to the ground...Youths from both parties intimidated those attending rallies of their opponents.

(National Democratic Institute for International Affairs; The Carter Center 1992, p. 45)

Despite the adoption of a multi-party parliamentary democracy in 1991, the negative influence of political party youth league members continues unabated in the country's third republic. For example, there was continued meddling in grassroots structures such as village and ward development committees under the guise of 'decentralisation of power' (Sichone 1996) witnessed during the UNIP era. This had been a dominant feature of the Movement for Multi-party Democracy (MMD). At the start of their party's third mandate, young party cadres under the MMD administration had become fully immersed in political and electoral violence and were allegedly involved in beating and harassing journalists from both private and public media organisations. They were also involved in harassing and intimidating political opponents, voters and the general citizenry. A case in point is the manhandling of Mr. Hakainde Hichilema, UPND President during the filing of nominations for the Chilanga by-elections in Lusaka Province in 2010. Next, an MMD youth chair threated the gang rape of FDD leader, Ms. Edith Nawakwi, for her critical stance against the MMD. Third, MMD cadres were also at the helm of violent confrontations, clashes and skirmishes with cadres from opposition parties PF and UPND during electoral campaigns. 
Some of the clashes between the PF and MMD in Lusaka revolved around restricting the access to market stores and other public spaces. Market places and bus stations became the centres for clashes between different political parties, to the point where one party would claim oversight of one station, and the other party another. This oversight, noted by Hansen (2010), extended to different cadres and factions unlawfully collecting or soliciting levies.

Thus, the trend of violent youth wings, synonymous with the former ruling MMD, has now spread to today's major political parties including the current ruling Patriotic Front (PF) and the opposition United Party for National Development (UPND). Their youth sections invariably remain indispensable for electoral canvasses. In what Bwalya (2017, p. 1554) describes as fiercely competitive electoral campaigns that have characterised Zambia's nascent multiparty political terrain, these youth cadres are a regular feature.

While young party stalwarts from the PF and UPND have risen to positions of eminence by perpetuating electoral violence, this does not apply to smaller parties. Because of their structures and membership, few of these smaller political parties that contested the nationwide presidency and parliamentary seats in 2016 seem to have had belligerent youth leagues, that is young party cohorts willing and able to engage violently with their opponents as obtains in PF, UPND and MMD. However, the country's ugliest acts of election-related violence took place during the 2016 elections, as discussed below.

\section{METHODOLOGY}

An event catalogue of occurrences of election-related violence in 2016 reinforces this reflection (see Figure 1). The initial premise is that since the 2011 elections, Zambia has witnessed unprecedented high levels of political intolerance and hostilities among political players, civil society organisations and sections of the media (Yezi Consulting and Associates 2013; Zambia Election Information Centre 2016). This reached a peak during the 2016 elections as violent incidents escalated the tension between political parties as well as between their respective supporters. The study split these events into five categories adapted from the qualitative study of party youth activists and low-intensity electoral violence in Ghana by Bob-Milliar (2014, p. 136).

- First, molestation and violent intimidation; these comprised alleged abduction, physical assault of political opponents using offensive weapons such as clubs, machetes, stones or petrol bombs.

- Second, seizure of public/state property and occupancy; these include incidences such as impounding the property of the electoral management body, including vehicles, polling materials (both ballot boxes and allegedly marked or unmarked ballot papers), and holding government staff hostage. 
- Third, protests and public disorder; these became commonplace occurrences in expressing political dissent. They include arson attacks, malicious damage to or setting private and public property alight, stoning private and public vehicles, blocking roads, and clashing with police as well as harassing journalists.

- Fourth, party property vandalising; another familiar and unpleasant albeit isolated practice in previous elections (2001, 2006, 2008, 2011 and 2015); this entails pulling down or defacing opponent's party campaign materials, attacking campaign vehicles, and damaging party offices.

- Finally, hate speech or violent rhetoric was an unprecedented occurrence and included verbal retaliation or threats, name-calling and insults, and offensive public statements.

For empirical evidence, the study analysed stories of electoral campaigns by one private online news platform, Lusaka Times. This news outlet has a balanced coverage of both ruling and opposition political party activities, including the events that took place between January and December 2016.

\section{RESEARCH FINDINGS}

The study revealed that throughout 2016 young political cadres from both the incumbent Patriotic Front (PF) and the leading opposition party, United Party for National Development (UPND) were active participants in political and electionrelated violence. In some incidences, as shown later in this paper, more senior leadership has also actively participated. In terms of actual political occurrences, most of these incidents in 2016 consisted of protests and public disorder, followed by molestation and violent intimidation. Peak months ran from May to August, prior to polling day and immediately after the announcement of election results (see Table 1).

The study revealed that several acts of violence by political party cadres were retaliatory. An impending attack by PF cadres on UPND offices thwarted by police in Lusaka's Rhodes Park area in May 2016, for example, was an act of retaliation. The previous day, altercations between PF and UPND cadres in Matero Township culminated in 'malicious damage and ransacking of the former's constituency offices'. The UPND, however, claimed they were provoked by PF cadres carrying pangas, machetes and axes who disrupted their youth assembly in the area (Lusaka Times, 9 May, 2016).

What is evident from this study is that the violent nature of young political party cadres evinces itself in some degree of lawlessness. For example, following the court appearance of their vice president for administration, UPND cadres mounted an unlawful procession blocking traffic in and out of Kitwe. 
Table 1: Cases of Election-Related Violence in Zambia 2016

\begin{tabular}{|l|c|c|c|c|c|c|}
\hline \multicolumn{7}{|c}{ Categories of Event Catalogue of Election Related Occurrences } \\
\hline Month & $\begin{array}{c}\text { Molestation/ } \\
\text { Violent } \\
\text { Intimidation }\end{array}$ & $\begin{array}{c}\text { Seizure Public/ } \\
\text { Private Property/ } \\
\text { Occupation }\end{array}$ & $\begin{array}{c}\text { Protests/ } \\
\text { Public } \\
\text { Disorder }\end{array}$ & $\begin{array}{c}\text { Party } \\
\text { Property } \\
\text { Vandalism }\end{array}$ & $\begin{array}{c}\text { Hate Speech } \\
\text { Violent } \\
\text { Rhetoric }\end{array}$ & TOTAL \\
\hline January & 3 & 3 & 3 & 2 & 2 & 13 \\
\hline February & 3 & 1 & 2 & 1 & 2 & 9 \\
\hline March & 2 & - & 3 & - & 4 & 9 \\
\hline April & 2 & - & - & 2 & 2 & 6 \\
\hline May & 4 & 1 & 4 & 2 & 3 & 14 \\
\hline June & 5 & - & 8 & 5 & 1 & 19 \\
\hline July & 2 & - & 4 & 2 & 1 & 9 \\
\hline August & 2 & 3 & 11 & 1 & - & 16 \\
\hline September & 1 & - & - & - & - & 1 \\
\hline October & 1 & - & 1 & - & - & 2 \\
\hline November & - & - & - & - & - & - \\
\hline December & - & - & - & - & - & - \\
\hline Total & 25 & 8 & 36 & 15 & 15 & 99 \\
\hline
\end{tabular}

Source: Compiled by author, 2018

As young party members from the UPND escorted their leader, a state police officer overseeing a checkpoint near the host hotel was beaten up. Similarly, in June 2016, UPND and PF members clashed following a supposedly peace-oriented engagement, a conflict management meeting at the Civic Centre in Mazabuka, Southern Province. The damage to the vehicles parked at the Civic Centre and injuries sustained of those shot by armed cadres was symptomatic of the cadres' sheer disregard of the law (Lusaka Times, 29 June 2016). The public disorder that characterised violent actions by young political cadres was in several instances preceded by public gatherings and/or rallies.

Further violence perpetuated during electoral campaigns was in some cases spontaneous and without justification. In the Kanyama compound of Lusaka, for example, during one of their campaigns UPND cadres ran amok damaging the front windscreens and sliding doors of five private minibuses parked at the local bus station (Lusaka Times, 27 July 2016). This public disorder prompted by young political party members affected journalists from both public and private media 
outlets, to the point of displeasing media heads like Richard Mwanza, Director General of the Zambia National Broadcasting Corporation (ZNBC). He threatened to switch off the cameras if political cadres continued with their unacceptable behaviour of harassing their reporters (Lusaka Times, 7 June 2016).

From a review of stories covered by the Lusaka Times, it was also clear that molestation and violent intimidation of political opponents was not confined to urban regions. In Muchinga Province, Shiwang'andu area, PF cadres attacked a UPND campaign team with sticks and stones, disrupting scheduled meetings. In retaliation, a group of youths in UPND attire damaged vehicles and property belonging to those suspected of being PF supporters in Lusaka's Northmead shopping area. The youth party cadres claimed their attacks were in revenge for the attack on their leaders in Shiwang'andu (Lusaka Times, 16 June 2016).

In the town of Monze, Southern Province, police prevented a PF youth mobilisation rally from being disrupted by UPND cadres, arresting two. In Namwala district in the same province, a female parliamentary candidate from the Forum for Democracy and Development (FDD), was brutally attacked by UPND cadres. In his reaction to this incident, FDD spokesperson Antonio Mwanza alleged that the attack was led by UPND's immediate past and aspiring candidate together with her team, extensively damaging the FDD candidate's vehicle and attempting to set it ablaze (Lusaka Times, 19 June 2016).

Later, in an apparent disagreement with the call by PF President Edgar Lungu for the country to hold a day of national prayer to end the political violence, Mwanza and the FDD media staff demanded introspection. They argued there was need to question who arms cadres with guns, pangas, military fatigue, money and beer (that is, whether it is God or politicians). Even though the Namwala incident was allegedly perpetrated by UPND cadres, Mwanza directed his demands to the $\mathrm{PF}$ and the government, querying, 'who was abetting and tolerating violence'? (Lusaka Times, 15 July 2016). Interestingly, Antonio Mwanza subsequently crossed over to the Patriotic Front where he is currently (2019) the deputy media director. This illustrates the argument by Bwalya and Sichone (2016) that defectors include ordinary members as well as former office bearers who move to join dominant or ruling parties.

As noted earlier, one of the significant occurrences prior to the 2016 elections was the impounding of the Electoral Commission of Zambia (ECZ) properties. This was at the height of the campaigns (see Figure 1).

Party cadres from the opposition UPND seized ECZ trucks in three different cities on suspicion of carrying pre-marked ballot papers. First was in Livingstone city, Southern Province, where UPND members impounded, damaged and searched eight new ECZ trucks. Second, the ECZ truck broke down in Senanga 
District, Western Province providing an opportunity for UPND cadres in the area to impound the truck on allegations that it had pre-marked ballot papers. In Kabwe, Central Province, cadres from the same party blocked the road, intercepted and impounded three ECZ trucks, and again similar allegations were advanced. Despite the searches of all these ECZ trucks (which yielded nothing) and the exercise monitored by officers from the Zambia Police, UPND cadres still seemed sceptical. They accompanied trucks from Livingstone to Lusaka as well as Kabwe to Mkushi alongside the police. The accompaniment was premised on ensuring that nothing was put in the trucks along the way. Some party officials justified their actions as 'praise-worthy alertness' (Lusaka Times, 7 August, 2016).

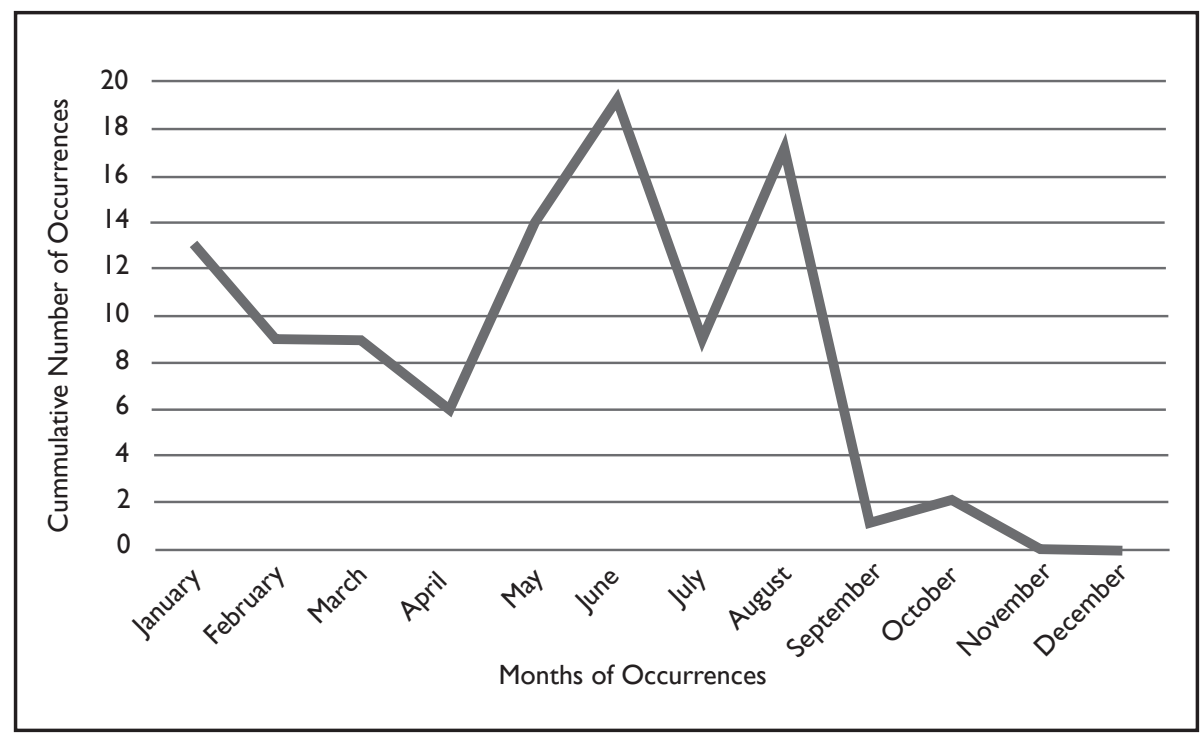

Source: Compiled from Lusaka Times, 2018

Figure 1: Cases of Election-Related Violence in Zambia - 2016

Party property vandalising is another incident-type that characterised the 2016 election campaigns. From accounts in the Lusaka Times, both PF and UPND party cadres participated in this sort of violence which included defacing and/ or pulling down billboards, and damaging offices and motor vehicles. As noted earlier, violent acts by political party cadres were in some cases retaliatory, and vandalising party property was no exception. Barely weeks after the UPND Chairperson for Elections, Ackson Sejani, vowed to protect their billboards from being vandalised by PF cadres, he had UPND cadres arrested for the same act. Addressing the media, he warned the PF to stop provoking his party beyond 
human patience, and that their preventive actions to protect their billboards should not be condemned. A month later, five UPND cadres in Lusaka's Cairo Road were arrested for defacing and removing PF bill boards and posters (Lusaka Times, 4 July, 2016).

Furthermore, the euphoria that characterised the filing of presidential nominations by PF presidential candidate Edgar Lungu in June 2016, culminated in damage to the UPND secretariat. Hordes of PF cadres violently attacked and damaged property belonging to UPND supporters. Acknowledging that nomination filing is cause for celebration, UPND Secretary-General Stephen Katuka, said it should not be an excuse for violence, abuse and intimidation (Lusaka Times, 2 June 2016). While he implored the police to arrest those that committed criminal acts regardless of political affiliation, his party's cadres in Livingstone were ambushing and stoning a PF campaign vehicle. The attack left two PF officials injured, one of them a former UPND member.

Unlike Mwanza, whose defection to the PF had no reprisals from the FDD, one of the victims in the Livingstone attack associated the incident with his defection. He lamented that, 'it is unfortunate that UPND is targeting its former members who have exercised their democratic right of joining the PF...' (Lusaka Times, 24 June 2016). While this incident may not have had the blessing of senior party officials within UPND, leaders from both PF and UPND are guilty of hate speech and violent rhetoric. For example, during a radio interview in a private local station the PF national youth chairperson, Steven Kampyongo, described leaders from the UPND as terrorists. This was in response to earlier remarks attributed to some senior UPND leaders who had appeared on the same platform previously and allegedly promised to break Kampyongo's lips (Lusaka Times, 17 June, 2016).

However, what is noteworthy from this exchange regarding the current discourse is the vaunt about the chairperson's support from youth members. He retorted that he was not threatened by the UPND leadership as he was youth chairperson in the PF and commanded the largest following of youth in the country. Whether this translates to having more young people at his disposal or the capacity to exert more violence against political opponents is unclear. However, comments from senior political leaders inadvertently encouraged young party cadres to see violence as the norm. For example Mumbi Phiri, PF Deputy Secretary-General, defended attacks on UPND supporters in the Sinda District of Eastern Province, by stating that 'political provocation' enraged the PF cadres (Lusaka Times, 28 January, 2016). Incensed by attacks on his party by PF cadres, including the Shiwang'andu incident mentioned earlier, UPND Vice President, Geoffrey Bwalya Mwamba, instructed youths from his party to 'hit back' whenever attacked by PF cadres. 


\section{DISCUSSION}

While Zambia's record cannot equal the scale of electoral violence elsewhere in Africa, as Bekoe (2010) and Burchard (2015) observe, the recurrent trend since 2011 is worrisome. Conflict and difference are inevitable aspects of every human society and Zambia's growing democracy is no exception. However, how these differences are handled may serve to engender political and particularly electoral violence. Of particular interest within the polity is the indispensable role of young political party cadres in driving electoral violence. It is evident from this study that at least four explanations can be advanced as motivation for their participation in electoral violence.

First, the association of young party cadres with either political or electoral violence has tangible roots in the country's second republic and one-party state (1973-1990). UNIP stalwarts and members of the youth league extended their mandate to include taking care of any 'dissenting voices'. Sadly, this entailed using militaristic and violent means. Agarwal (2012) aptly notes that each generation partly inherits attitudes and beliefs towards politics from earlier generations, and that these attitudes and values are partly a reaction to on-going (contemporary) politics. Thus, successive ruling parties have included young party stalwarts with aggressive and belligerent approaches, albeit to different degrees. From UNIP's successor the MMD, to the PF, including the opposition UPND, youth leagues see themselves as front-line disciplinarians.

Second, some senior party leaders bluntly acknowledge inflaming violence, while others couch their incitement in an oblique fashion. One example is that of a leader of a prominent political party during the 2018 campaign for the Chilanga constituency by-elections in Lusaka Province. He reportedly expressed his gratitude to his youth cadres for defending themselves against what he described as 'PF thugs'. He further urged young party stalwarts to defend themselves whenever attacked. What is evident from this study is that leaders from both the PF and the UPND have openly incited young party cadres to use violence against their opponents. Such acts contribute to the normalising of violence among young people.

The third incentive for young party cadres' predisposition to electoral violence includes material benefits such as branded caps, T-shirts and wrappers. Bwalya (2017, p. 1559) considers these to be intricately woven into the fabric of electoral campaigns. Bwalya further posits that while this unique clientelist plan targets community groups, young party members are not left out. They too receive these clothing items. Not only are young people recipients of material goods but also of electoral campaign promises such as job creation. It is this lack of job opportunity that, claim Forti and Maina (2012, p. 76), leads to a cohort 
of idle and frustrated youth who constitute a likely target for recruitment into negative criminal or violent activities. Their pre-disposition to violent conduct during elections is aggravated by drug abuse which may or may not be facilitated by their sponsors. A study commissioned by the United Nations Development Programme (UNDP) as part of Election Cycle support in 2017, found that party cadres abuse both cannabis and alcohol. To some extent this drives them to engage in violence, particularly during elections (Namaiko \& Etyang, 2017) when they intimidate rival parties and voters in acts of hooliganism inimical to social and political norms.

Fourth, young party cadres' rudimentary understanding of multiparty democracy seems to be a factor in dealing with dissent. While senior party leaders do communicate civilly when faced with political differences, young party stalwarts are seldom courteous. Their take is that, as representatives of dominant political parties, they should always lead and/or win while others follow or lose. Findings of the European Union Election Observation Mission in 2016 revealed that smaller parties and independent candidates in the Copperbelt, Eastern, North-Western and Southern provinces faced intimidation from the larger PF and UPND (European Union, 2016). In addition, cadres from these two parties behaved as though no other party should be permitted to campaign in their respective strongholds. This echoes the violent counter and retaliatory attacks alluded to previously in Shiwang'andu constituency and Lusaka's Northmead areas by PF and UPND cadres respectively.

While the main focus of this paper has been on inter-party election-related battles, the PF is not immune to intra-party clashes. Following the demise of $\mathrm{Mr}$. Sata in 2014, the PF was once more immersed in internal party battles, particularly over who should stand as president in the January 2015 presidential by-elections. After an extended tussle between two distinct camps, one led by former Vice President Dr. Guy Scott and the other by Mr. Edgar Lungu, there was a churchbrokered reconciliation. The polarisation may have run deep, particularly among lower-level party members, but the presence of church leaders triggered a reunion process that gave the $\mathrm{PF}$ its presidential candidate.

Further, seemingly as a repeat of the dissatisfaction in 2011 over parliamentary adoptions in some Ndola constituencies, PF cadres did not welcome all the 2016 adoptions. For example, some cadres from Chimwemwe and Wusakile constituencies in Kitwe alleged that parliamentary candidates were imposed on them and they felt that leaders with grassroots support were left out. While senior leader's preferences led to low-level intra-party tensions, the final outcome was that independent candidates with popular support won both constituencies.

As evidenced from the findings, electoral violence takes several forms, notably physical attacks and intimidation. The occurrence of the latter is not restricted 
to pre-election or election periods but post-election too. For example, following the inauguration of PF President-elect Edgar Chagwa Lungu, a PF youth leader in Lusaka warned civil servants not to expect any salary increments as they did not support his party's re-election (Lusaka Times, 12 September, 2016). Such remarks against ordinary citizens and professional civil servants are not just an affront to basic human rights but an assault on the very essence of democracy, that is, an assault on the right of the people to vote for and thus elect representatives of their choice.

On the other hand, the destruction of property including vehicles and buildings raises questions of whether any line can be drawn between electoral violence and criminality, or whether perpetrators of these acts are in fact young people. There is a thin line between election-related violence and criminality, as some youth leagues are led by what could be termed 'youth claimants'. A study by Yezi Consulting and Associates (2013) observed that the chairpersons of the youth wings of three major political parties in Zambia are over 40 years old. Not only is this above the state's prescribed youth age range (15-35 years), but these supposed youth leaders invariably see violent acts as the norm. This begs the question of whether the real youth, that is those in the 15-35 year range, would consider refraining from using violence.

It may be that this aspect of age is not central as all political parties draw considerable strength from these young party stalwarts whose primary responsibility is broadening party influence. While some may function as foot soldiers and undertake genuine functions, 'noble roles' such as membership recruitment, the vast majority are guilty of perpetrating wrongs against their political opponents. This is why young party stalwarts are indispensable in political parties. Both incumbents and opposition parties need them and this study attests to their role in Zambia's political history. During political campaigns, gangs of both unarmed and armed young party cadres are behind the wheels of electoral violence.

Zambia's 2016 political campaigns also exhibited what appears to be a growing habit of hate speech or violent political rhetoric. Messages by often senior political leaders are couched in provocative and hateful language resulting in long-lasting violence by their rank and file. This violent rhetoric may not dissipate once the political battles have waned and the study by Namaiko and Etyang noted the increasing use of incendiary remarks by politicians. They report that these remarks, which often characterise political rallies and social media platforms, revolved around 'ethnicity and other falsehoods' (Namaiko \& Etyang, 2017, p. 26).

Another aspect evident from the study is the disregard of law and public order, in particular the provisions of the country's electoral code of conduct. This disregard of the law parallels the proclivity of party cadres to a militaristic outlook, a development that parties seem to tolerate. The conduct of these party 
cadres is reminiscent of UNIP's one-party state's militants who, according to Phiri (2001, p. 237) are 'a law onto themselves, no one dared to challenge them at least openly'. However, in the current democratic dispensation this behaviour should not be allowed to take hold. Permitting party cadres to remain unchallenged runs counter to the consolidation of democracy.

An example that may illustrate this dent on democracy, is the Lusaka mayoral by-election held in 2018. From a total of 839027 registered voters only 131777 (15.88\%) participated in the elections (Electoral Commission of Zambia 2018). Although the leading opposition party leader claimed that voter apathy was due to failure by the Electoral Commission of Zambia (ECZ) to run credible elections, others saw it differently. The low voter turnout was attributed to widespread electoral violence which resulted in over $80 \%$ of the voters staying home despite the election day being declared a holiday (Chali 2018).

As a consequence, Koko (2013) notes, election related violence undermines democratic institutions. It also diminishes the credibility of institutions (including political parties) responsible for entrenching democracy. The observations from Zambia's 2016 election campaigns point to the cultivation of a climate of fear perpetuated by young party cadres. This is described as a worrisome trend of violence and intimidation, endangering a secure environment for the democratic process and a hindrance to citizens - voters, political party supporters, and political candidates - participating in elections (The Carter Center 2016, p. 34).

\section{CONCLUSION}

The study identifies at least four main aspects of electoral violence. First, the nature and extent of electoral violence being witnessed today among Zambia's young party cadres may be the fruits of seed sown during UNIP's one-party state. The notoriety of UNIP's uniformed party militants and the aggressive behaviour against those with dissenting voices is being re-enacted today among young members from major political parties, notes Phiri (2001). Given the growing hooliganism, militancy and sheer disregard of the law during elections (in particular the electoral code of conduct) these party cadres are slowly becoming unaccountable to party discipline. From UNIP to MMD, nearly all political parties, including the $\mathrm{PF}$, are offshoots of the MMD. This means that some sort of umbrella youth league modus operandi needs to cover behaviour in all parties.

Second, the principal drivers of election-related violence are party cadres from the two leading political parties in Zambia, the PF and UPND. They are the front-runners in implementing electoral violence; their support makes some senior party members equally culpable. The expectation that these young party stalwarts should serve as conduits between their respective parties and the populace to disseminate party ideals and programmes, remains elusive. 
Third, violence committed by these party loyalists is both incidental and strategic, to use Burchard's (2015) categorisation. Often parties' public gatherings and/or rallies engendered public disorder and violent action, with each party on the lookout for the opposition's political events so that skirmishes were often premeditated. Conversely, the violence during vote canvassing was incidental, as indicated by some of the cases in this study. Incidental or strategic electoral violence as executed by young party cadres undermines the consolidation of a fledgling democracy such as Zambia's.

Given the intensity of violence during electoral campaigns, and the fatalities in some cases, the distinction between criminality and mere election-related clashes is obscured. The violence orchestrated by armed party cadres in 2018, during a parliamentary by-election in Lusaka Province, led some political stakeholders to express pessimism about Zambia's 2021 general elections (The Zambian Observer, 6 June, 2018). They fear that, if the current cohort of weaponwielding young party members are not restrained, there is a great propensity for attitudes to harden and trigger more troubles in future.

Fourth, the predisposition of young party cadres to election-related violence may perhaps be driven by their rudimentary understanding of pluralist politics. While most of their senior leaders may communicate in a civil fashion when faced with differences, young party cadres are seldom socialised to do the same. For the latter, political disagreements are synonymous with violence. In peacebuilding parlance, the claim is that the political socialisation of the current cohort of young people lacks peace-oriented mechanisms in dealing with or handling political dissent and conflicts.

Finally, as Zambia anticipates its next election in 2021, it is imperative that young party cadres are constructively engaged and drawn into the political life of the country. Failure to do so may result in violent political outbursts before, during and after the elections.

\section{---- REFERENCES}

Adolfo, EV, Kovacs, MS, Nyström, D \& Utas, M 2012, 'Electoral Violence in Africa', The Nordic Africa Institute Policy Notes, Issue 3, pp. 1-4.

Agarwal, RC 2012, Political theory: Principles of political science, S. Chand, New Delhi. Akpan, DA 2015, 'Appraisal of the role of political violence: The development of youths in Nigeria in the 21st Century', African Research Review, vol. 9, no. 3, pp. 147-156.

Barber, BK 2013, 'Political conflict and youth', The Psychologist, vol.26, no 5, pp. 336339.

Bekoe, D 2010, 'Trends in electoral violence in sub-Saharan Africa', USIP PeaceBrief, Issue 13, pp. 1-5. 
Berckmoes, LH 2015, 'Youth, politics and violence in Burundi: Gullible followers or tactics actors', In: FVS. a. VM Reyntiens, ed. L'Afrique des Grands Lacs: Annuaire 2014-2015, pp. 21-3.

Birch, S \& Muchlinski, D 2017, 'The Dataset of Countries at Risk of Electoral Violence', Terrorism and Political Violence, Volume DOI: 10.1080/09546553.2017.1364636, pp. 1-20.

Bob-Milliar, GM 2014, 'Party youth activists and low-intensity electoral violence in Ghana: A qualitative study of party foot soldiers' activism', African Studies Quarterly, vol. 15, no. 1, pp. 125-152.

Bosi, D \& Malthaner, S 2014, 'A Contentious Politics Approach to the Explanation of Radicalization', In: L Bosi, C Demetriou \& S Malthaner, eds. Dynamics of Political Violence: A Process-Oriented Perspective on Radicalisation and the Escalation of Political Conflicts, Ashgate, Farnham, pp. 1-23.

Burchard, SM 2015, Electoral violence in sub-Saharan Africa: Causes and Consequences, First Forum Press, Boulder Co.

Bwalya, J 2017, 'Unravelling clientelism in the Zambian electoral campaigns', Third World Quarterly, vol, 38, no.7, pp. 1551-1565.

Bwalya, J \& Sichone, O 2016, 'I Will Crawl Before You - Political endorsements, defections and patronage in Zambian elections', Africa Insight, vol. 46, no. 3, pp. 118-130.

Chali, R 2018, 'Only 15\% voted in Lusaka Mayoral elections', Lusaka Times, 30 July, pp. 1-3.

Chiluba, FTJ 1995, Democracy: The challenge of change, Multimedia, Lusaka.

Electoral Commission of Zambia, 2018. Electoral Commission of Zambia. [Online] Available at: http://ecz-news.com/news/official-results-of-the-26th-july2018-elections/[Accessed 9 September 2018].

Erdmann, G \& Simutanyi, N 2003, 'Transition in Zambia: The Hybridisation of the Third Republic', Konrad Adenauer Foundation, Occasional Papers, Issue December, pp. 1-97.

European Union, 2016. Final Report - Republic of Zambia: General Education and Referendum, Lusaka: European Union Election Observation Mission.

Fjelde, H \& Hoglund, K 2014, 'Electoral Institutions and Electoral Violence in SubSaharan Africa', British Journal of Political Science, Issue 46, pp. 297-320.

Forti, D \& Maina, G 2012, 'The danger of marginalisation: An analysis of Kenyan youth and their integration into political, socioeconomic life', ACCORD Monograph Series, Issue 1, pp. 55-85.

Hansen, KT 2010, 'Changing youth dynamics in Lusaka's informal economy in the context of economic liberalization', African Studies Quarterly, vol. 11, nos 2 \& 3, pp. 13-27.

International Institute for Democracy and Electoral Assistance 2015, 'Youth 
participation in electoral processes: new roles for African electoral management bodies', IDEA Policy Brief, Issue November, pp. 1- 4.

Koko, S 2013, 'Understanding Election Related Violence in Africa: Patterns, Causes, Consequences and a Framework for Preventive Action', Journal of African Elections, vol. 12, no. 33, pp. 51-88.

Leonard, DK 2010, 'Elections and conflict resolution in Africa', In: KT Matlosa, GM Khadiagala \& V Shale ed., When elephants fight: preventing and resolving election-related conflicts in Africa, EISA, Johannesburg.

Namaiko, T \& Etyang, O 2017, 'Conflict structural vulnerability assessment (SVA) Zambia' , United Nations Development Programme, Lusaka.

National Democratic Institute for International Affairs; The Carter Center 1992, The October 31, 1991, National Elections in Zambia, National Democratic Institute for International Affairs. Washington, D.C.

Okafor, S 2017, 'Youth involvement in political violence/thuggery: A counter weight to democratic development in Africa', Journal of Political Sciences and Public Affairs, vol. 5, nol. 3, pp. 1-4.

Omotola, S 2010, 'Explaining Electoral Violence in Africa's new Democracies', Journal of Conflict Resolution, vol. 10, no. 3, pp. 51-73.

Paalo, SA 2017, 'Political party youth wings and political violence in sub-Saharan Africa: A case of Ghana', International Journal of Peace and Development Studies, vol. 8, no. 1, pp. 1-14.

Phiri, BJ 2001, 'Colonial Legacy and the Role of Society in the Creation and Demise of Autocracy in Zambia, 1964-1991', Nordic Journal of African Studies, vol. 10, no. 2, pp. 224-244.

Scott, I 1976, 'Party functions and capabilities: The local level UNIP organization during the first republic (1964 -1974)', African Social Research, Issue 72, pp. $107-128$.

Sichone, OB 1996, 'The Problems of the State and Civil Society', In: OB Sichone \& B Chikulo, eds. Democracy in Zambia: Challenges for the Third Republic, Sapes Books, Harare.

The Carter Center 2016, The Carter Center's Experts Mission to the Zambian Presidential and Parliamentary Elections 2016 - Final Election Report, Carter Center, Lusaka.

Umar, BM 2016, 'Political Violence Amongst Youth Groups in Africa's Budding Democracies - An Explorative Studies of Concepts, Issues and Experiences', Research on Humanities and Social Sciences, vol. 6, no. 17, pp. 146-153.

Yezi Consulting and Associates 2013, Political governance study in Zambia, Diakonia Zambia, Lusaka.

Zambia Election Information Centre 2016, 2016 Pre-election citizens report, Zambia Election Information Centre, Lusaka. [Accessed 3 April 2018] 